DANIEL MOUREIRA FONTES LIMA

INFLUÊNCIA DA RAZÃO DE RECIRCULAÇÃO NA PRODUÇÃO DE HIDROGÊNIO EM REATOR ANAERÓBIO DE LEITO FIXO

São Carlos, SP

2011 

DANIEL MOUREIRA FONTES LIMA

\section{INFLUÊNCIA DA RAZÃO DE RECIRCULAÇÃO NA PRODUÇÃO DE HIDROGÊNIO EM REATOR ANAERÓBIO DE LEITO FIXO}

Dissertação apresentada ao Programa de Engenharia Hidráulica e Saneamento da Escola de Engenharia de São Carlos Universidade de São Paulo, para obtenção do Titulo de Mestre em Ciências (Engenharia Hidráulica e Saneamento)

Orientador: Professor Dr. Marcelo Zaiat

São Carlos, SP

2011 
REPRODUCTION AND RELEASE OF THE WHOLE CONTENT OR PART OF THIS THESIS ARE AUTHORIZED, BY ANY ELECTRONIC OR CONVENTIONAL WAY, FOR STUDY AND RESEARCH PURPOSES, SINCE THE SOURCE IS CITED

Card catalog prepared by the section of Information Treatment of Library service - EESC / USP

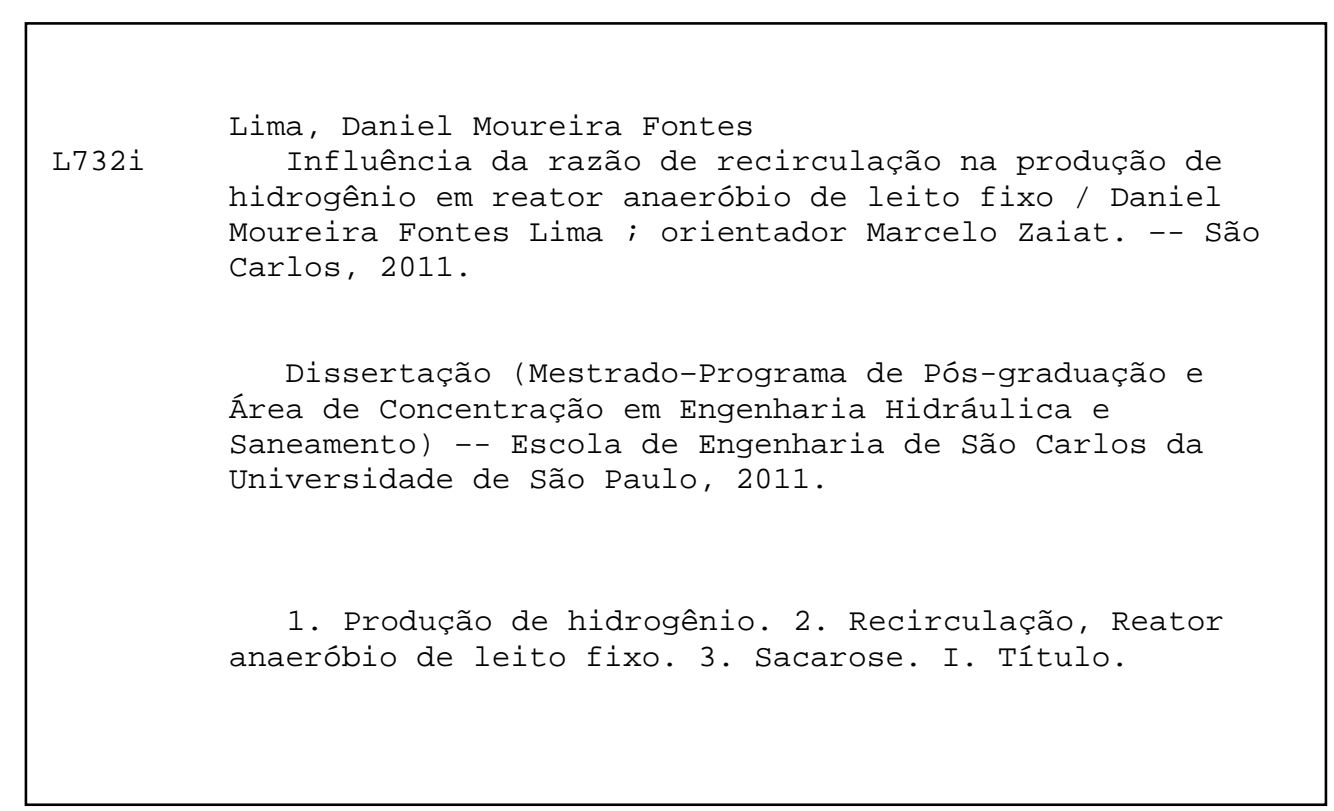


Candidato: Engenheiro DANIEL MOUREIRA FONTES LIMA

Dissertação defendida e julgada em 18/03/2011 perante a Comissão Julgadora:

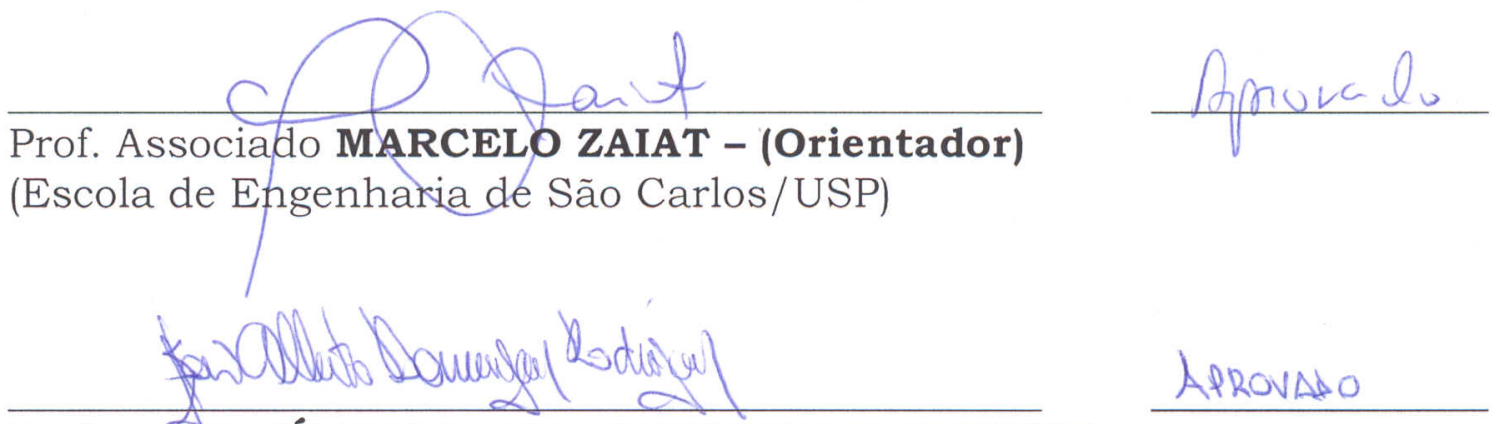

Prof. Dr. JOSÉ ALBERTO DOMINGUES RODRIGUES

(Escola de Engenharia de Mauá/EEM)

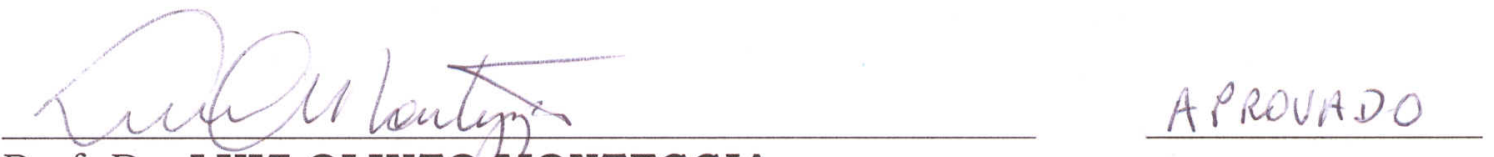

Prof. Dr. LUIZ OLINTO MONTEGGIA

(Universidade Federal do Rio Grande do Sul/UFRGS)

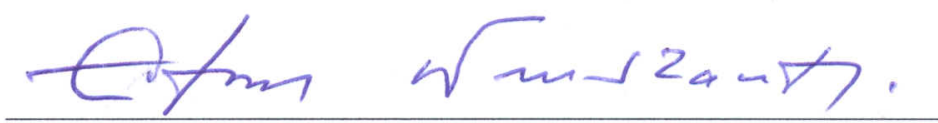

Prof. Titular EDSON CEZAR WENDLAND

Cóordenador do Programa de Pós-Graduação em

Engenharia Hidráulica e Saneamento)

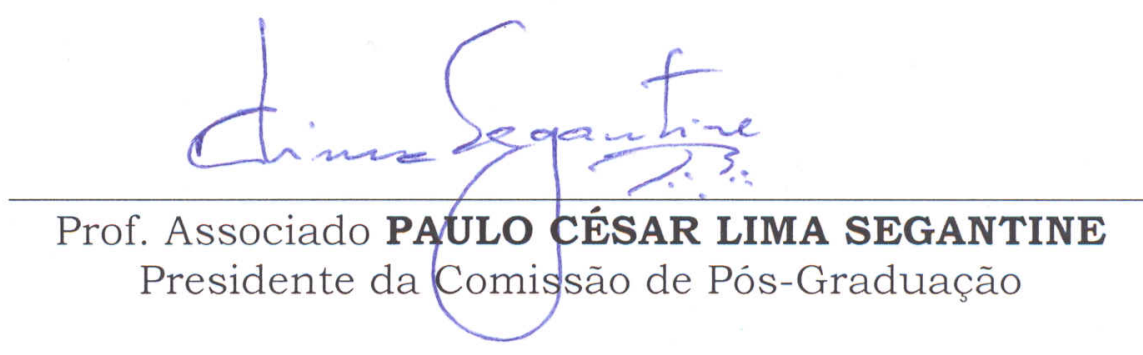



À minha mãe Rosângela Aos meus irmãos Arthur e Deborah Ao meu pai Oscar (in memorian) À minha avó Ruth 

"So make your way to the ocean"

Beulah 



\section{AGRADECIMENTOS}

Em primeiro lugar ao Pai Celestial.

À minha família, por ter me dado todas as condições de sair de casa, ir para tão longe e obter sucesso.

Ao meu orientador Marcelo Zaiat. Por ter sido mais do que um orientador, por ter sido um amigo e principalmente um exemplo. As coisas ficam mais simples quando você tem alguém como ele para se espelhar.

A amiga Pilar, por toda a ajuda em tudo desde que entrei no laboratório até a finalização do meu trabalho.

Aos professores Eugenio Foresti e Edson Luis Silva pelas sugestões na qualificação e à professora Maria Bernadete.

Ao professor Eugenio Foresti, meu primeiro orientador no mestrado, pelo acolhimento e aconselhamentos.

A Carol Zampol, por toda a ajuda com a cromatografia e pelos momentos especiais durante a minha pesquisa.

A Wojtyla, Marcell e Verônica, pois foi um prazer imenso poder trabalhar e aprender ao lado de vocês. Muito obrigado por toda ajuda, sem vocês teria sido muito mais complicado.

Aos meus amigos que ingressaram comigo no mestrado e se tornaram pessoas importantes para toda a vida: Rafael Bazola, Tiago, Mari Carosia, Fabi, Guilherme e Davi. E ao português Luis, que não era do curso mas é tão importante quanto.

Aos membros da diretoria Michael, Chagas, Álvaro, Felipe e Rérisson. O Nordeste vai dominar o mundo, galera! Vocês são irmãos para sempre.

Ao pessoal da Republica Federativa de Sergipe: Adriano, Vinícius, Gustavo e Andra. Foi muito bom poder morar tão harmoniosamente com vocês. Vou sentir saudades.

A Ligia por todo o tempo junto e toda a paciência e ajuda na transição Aracaju/São Carlos. Muito obrigado por ter feito parte disso tudo.

A todo o pessoal do LPB: Theo, Bruna, Gustavo, Dagoberto, Guilherme, Jorge, Fabrício, Juliana, Felipe, Mara, Regiane Correa, Regiane, Janja, Sandra, Flávia, Betão, Eduardo, Tiago Martins, Djalma, Adriana, Priscila, Eloísa e Isabel. Trabalhar neste laboratório foi a melhor experiência da minha vida.

À Escola de Engenharia de São Carlos, ao SHS, ao CNPQ e à FAPESP pelo apoio.

E a todos que por acaso eu tenha esquecido de mencionar. Não é uma simples menção em um papel que irá tirar a importância de toda ajuda que recebi durante esse caminho. 



\section{RESUMO}

Lima, D.M.F. Influência da razão de recirculação na produção de hidrogênio em reator anaeróbio de leito fixo. Dissertação (Mestrado) - Escola de Engenharia de São Carlos Departamento de Hidráulica e Saneamento, Universidade de São Paulo, 2011.

A presente pesquisa avaliou diferentes razões de recirculação do meio líquido com a finalidade de identificar a melhor condição de mistura para uma produção elevada e contínua de hidrogênio em um reator anaeróbio de leito fixo com fluxo ascendente alimentado com um meio contendo sacarose como fonte de carbono e uréia como fonte de nitrogênio. Foi utilizado polietileno de baixa densidade como meio suporte para imobilização da biomassa. O experimento foi iniciado com ensaios hidrodinâmicos (pulso, utilizando dextran blue como traçador) que determinaram as seguintes razões de recirculação em relação à vazão de alimentação utilizadas: $\mathrm{R}=0,25,0,5,1,0$ e 2,0. $\mathrm{O}$ experimento foi realizado em duas etapas, nas quais foram operados dois reatores idênticos simultaneamente, testando-se duas razões de recirculação diferentes. A DQO da água residuária foi de $2000 \mathrm{mg} . \mathrm{L}^{-1}$. O tempo de detenção hidráulica teórico foi de 2 horas e a temperatura foi mantida em $25^{\circ} \mathrm{C}$. A remoção de sacarose apresentou valores médios de $67 \%, 79 \%, 71 \%$ e $70 \%$ para $\mathrm{R}=0,25,0,5,1,0$ e 2,0, respectivamente. Os valores médios de rendimento de hidrogênio foram 1,14 mol H . $\mathrm{mol} \mathrm{sac}^{-1}$, 1,43 $\mathrm{mol} \mathrm{H}_{2} \cdot \mathrm{mol} \mathrm{sac}^{-1}$, $1,34 \mathrm{~mol} \mathrm{H}_{2} \cdot \mathrm{mol} \mathrm{sac}^{-1}$ e $0,86 \mathrm{~mol} \mathrm{H}_{2} \cdot \mathrm{mol} \mathrm{sac}^{-1}$ e de produção volumétrica de hidrogênio foram 74,34 mL H $\mathrm{H}_{2}$ (h.L) $)^{-1}$, 124,78 $\mathrm{mL} \mathrm{H}_{2}$.(h.L) $)^{-1}$, 96,57 $\mathrm{mL} \mathrm{H}_{2}$.(h.L) ${ }^{-1}$ e 73,49 mL $\mathrm{H}_{2}$.(h.L) $)^{-1}$ para as vazões de recirculação de $0,25,0,5,1,0$ e 2,0, respectivamente. O biogás produzido foi composto de $\mathrm{H}_{2}$ e $\mathrm{CO}_{2}$, com valores percentuais médios para $\mathrm{H}_{2}$ de $50 \%, 56 \%, 56 \%$ e $46 \%$ para $\mathrm{R}=0,25,0,5,1,0$ e 2,0, respectivamente. Não houve presença de metano em nenhuma fase de operação. Os principais produtos intermediários produzidos durante a produção de $\mathrm{H}_{2}$ foram ácido acético, ácido butírico e etanol, de forma similar para todas as fases de recirculação. Analisando todos os parâmetros de operação, foi possível notar que a melhor vazão de recirculação obtida foi de $\mathrm{R}=0,5$. Ajustando os dados obtidos a uma função polinomial, porém, chegou-se a um ponto de ótimo em $\mathrm{R}=0,6$. Durante os experimentos observou-se uma queda na produção do biogás, provavelmente por atuação de microrganismos consumidores deste.

Palavras chave: produção de hidrogênio, recirculação, reator anaeróbio de leito fixo,sacarose. 


\section{AbSTraCT}

Lima, D.M.F. Influence of recirculation rate in biohydrogen production in an anaerobic upflow fixed-bed reactor (Master Degree) - School of Engineering of São Carlos, Department of Hydraulics and Sanitation, University of São Paulo, São Carlos, 2011.

The present research evaluated different recirculation rates of the liquid medium for the purpose of identify the best mixture condition for a high and continuous hydrogen production in an anaerobic upflow fixed-bed reactor fed with a medium containing sucrose as carbon source and urea as nitrogen source. Low density polyethylene was used as medium for biomass immobilization. The experiment began with hydrodynamic tests (pulse, using dextran blue as tracer) which led to the following recirculation rates related with the feed flow rate used in this work: $\mathrm{R}=0,25,0,5,1,0$ and 2,0. The experiment was conducted in two stages, where two identical reactors were operated simultaneously, by testing two different recirculation rates. COD from wastewater was $2000 \mathrm{mg} \mathrm{L}^{-1}$. The theoretical hydraulic retention time was 2 hours and the temperature was maintained at 25 C. The average values of sucrose consumption were $67 \%, 79 \%, 71 \%$ and $70 \%$ for $\mathrm{R}=0,25,0,5,1,0$ and 2,0 , respectively. The average values of hydrogen yield were 1,14

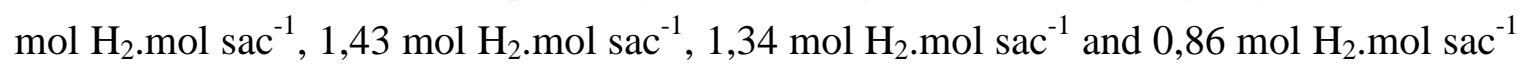
and of hydrogen production rate were $74.34 \mathrm{~mL} \mathrm{H}_{2}$.(h.L) ${ }^{-1}, 124.78 \mathrm{~mL} \mathrm{H}_{2}$.(h.L $)^{-1}, 96.57$ $\mathrm{mL} \mathrm{H}_{2}$.(h.L) $)^{-1}$ and $73.49 \mathrm{~mL} \mathrm{H}_{2}$.(h.L) ${ }^{-1}$ for recirculation rates of $0.25,0.5,1.0$ and 2.0, respectively. The biogas produced was composed by $\mathrm{H}_{2}$ and $\mathrm{CO}_{2}$, with average values for $\mathrm{H}_{2}$ of $50 \%, 56 \%, 56 \%$ and $46 \%$ for $\mathrm{R}=0,25,0,5,1,0$ and 2,0, respectively. Methane was not detected. The main intermediate products produced during the hydrogen production were acetic acid, butyric acid and ethanol, similar in all stages of recirculation. Analyzing all operating parameters, it was identified that the better recirculation rate obtained during the experiments was $R=0.5$. Adjusting all data obtained with a polynomial function, it was found a optimal recirculation rate of $\mathrm{R}=0.6$. During the experiments there was a drop in biogas production, probably by the activity of microrganisms consumers of this biogas.

Key words: hydrogen production, recirculation, anaerobic upflow fixed-bed reactor, sucrose. 


\section{SUMÁRIO}

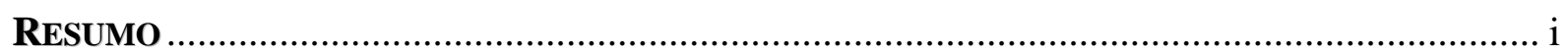

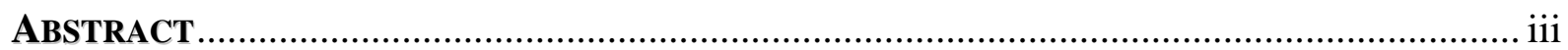

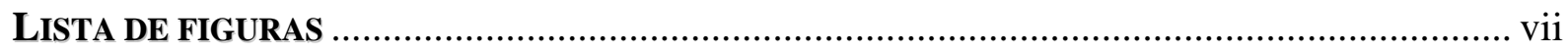

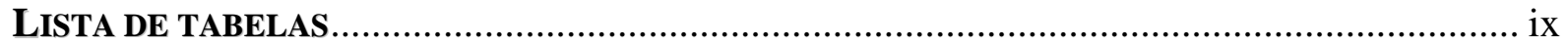

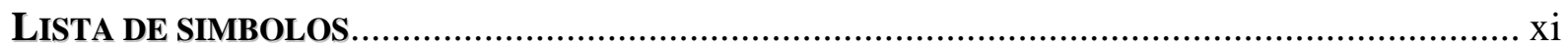

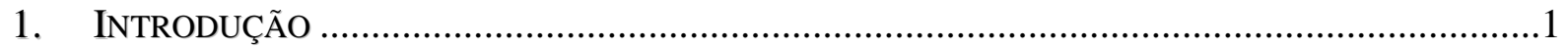

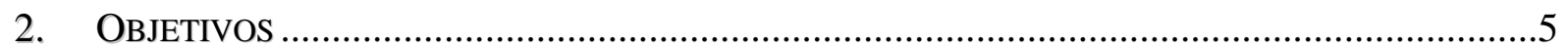

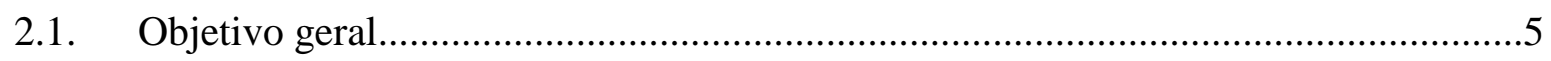

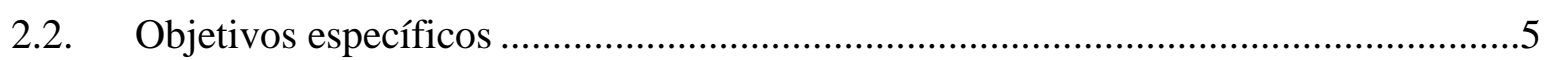

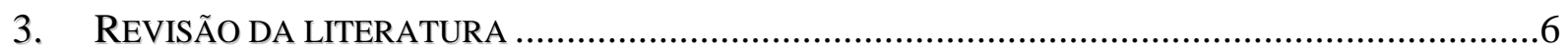

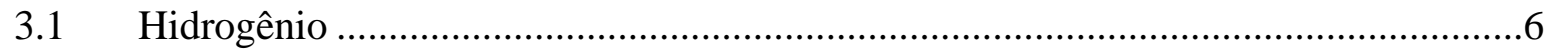

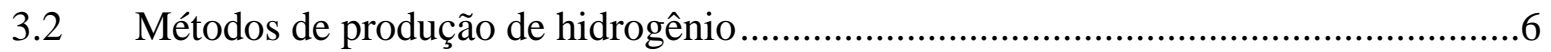

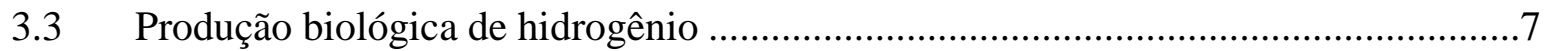

3.4 Produção de hidrogênio em reatores anaeróbios ....................................................9

3.4.1 Influência do TDH (Tempo de Detenção Hidráulica) ..................................10

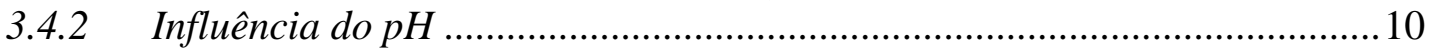

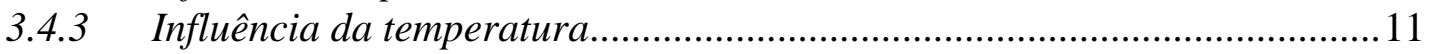

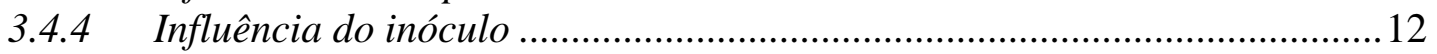

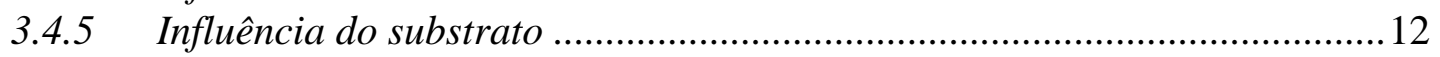

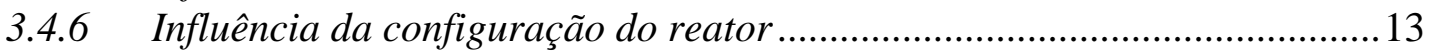

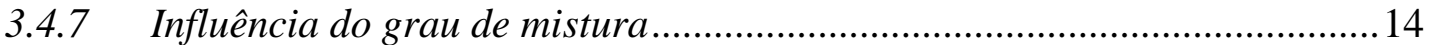

3.5 Microbiologia da produção de hidrogênio .............................................................16

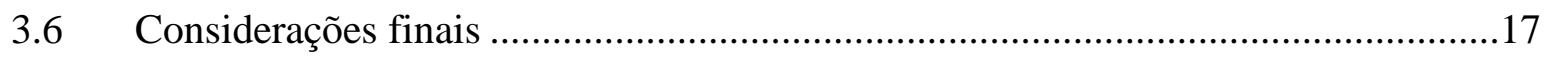

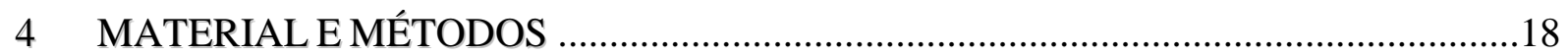

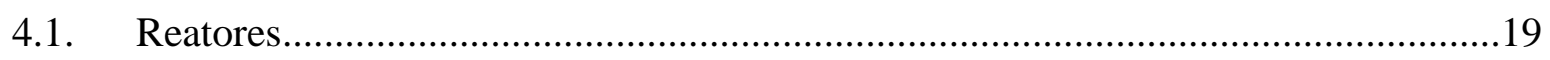

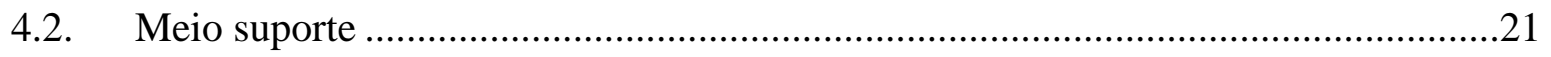

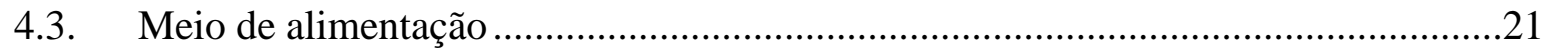

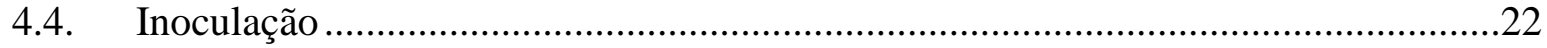

4.5. Procedimento experimental - operação dos reatores e ensaios hidrodinâmicos .......23

4.6. Medição da produção de hidrogênio, monitoramento e análises fisico-químicas dos demais parâmetros e exames microbiológicos ..........................................................25

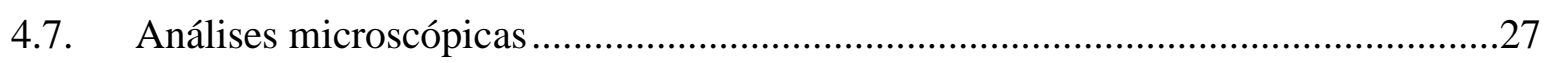

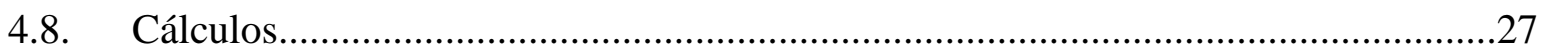

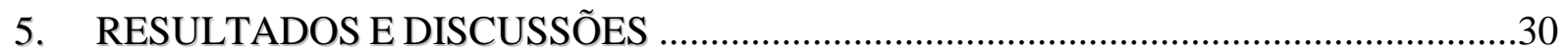


5.1 Escolha da faixa de razão de recirculação aplicada por meio de ensaios

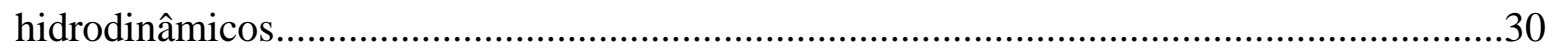

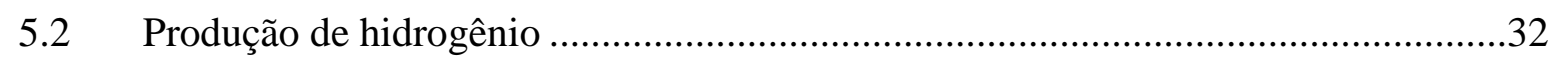

5.3 Geração de produtos de fermentação em meio líquido..........................................52

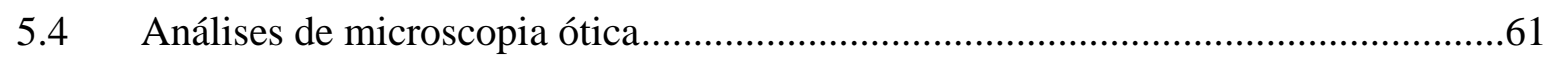

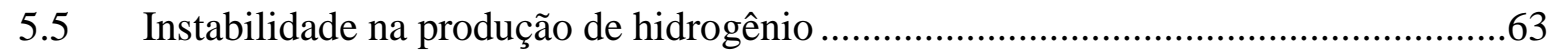

5.6 Perfis dos parâmetros de monitoramento ao longo do reator ..................................65

5.7 Comportamento hidrodinâmico dos reatores após as operações ..............................69

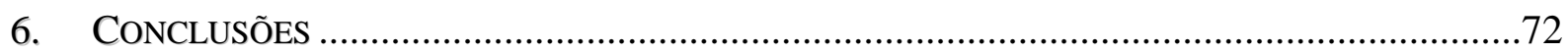

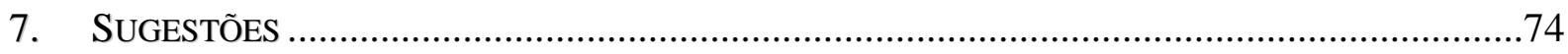

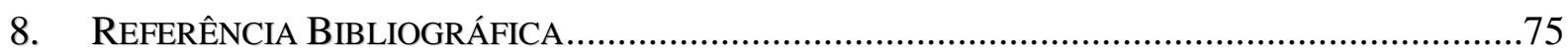




\section{LISTA DE FIGURAS}

Figura 3.1 - Processo de conversão anaeróbia da matéria orgânica (Chernicharo, 1997;

Speece, 1996)

Figura 4.1 - Esquema geral dos experimentos realizados

Figura 4.2 - Aparato experimental para produção de hidrogênio

Figura 5.1 - Curvas de concentração do traçador em função do tempo

Figura 5.2 - Produção de biogás $\left(Q_{G}\right)$ para $\mathrm{R}=0,25(\bullet), \mathrm{R}=0,5(\bullet), \mathrm{R}=1,0(\Delta)$ e $\mathrm{R}=2,0$ (匹) ..33

Figura 5.3 - Eficiência de remoção de sacarose para $R=0,25(\circ), R=0,5(\bullet), R=1,0(\Delta)$ e

$\mathrm{R}=2,0(\square)$

Figura 5.4 - Distribuição em porcentagem de $\mathrm{H}_{2}\left(\% \mathrm{H}_{2}\right)$ para $\mathrm{R}=0,25(\circ), \mathrm{R}=0,5(\diamond)$,

$\mathrm{R}=1,0(\Delta)$ e $\mathrm{R}=2,0(\square)$ e de $\mathrm{CO}_{2}\left(\% C O_{2}\right)$ para $\mathrm{R}=0,25(\circ), \mathrm{R}=0,5(\diamond), \mathrm{R}=1,0(\Delta)$ e $\mathrm{R}=2,0$

$(\square)$

Figura 5.5 - Vazão molar de hidrogênio $\left(v_{H 2}\right)$ para $R=0,25(\bullet), R=0,5(\diamond), R=1,0(\Delta)$ e $\mathrm{R}=2,0(\mathbf{\square})$

Figura 5.6 - Rendimento de hidrogênio $\left(Y_{H 2}\right)$ para R0,25 ( ), R0,5 (•), R1,0 ( $\Delta$ ) e R2,0

(घ)

Figura 5.7 - Produção volumétrica de hidrogênio (HPR) para $R=0,25(\bullet), R=0,5(\diamond)$,

$\mathrm{R}=1,0(\mathbf{\Delta})$ e $\mathrm{R}=2,0(\mathbf{\square})$

Figura 5.8 - Relação entre $\mathrm{Y}_{\mathrm{H} 2}$ e $\mathrm{N}$

Figura 5.9 - Relação entre N e a razão de recirculação (R)

Figura 5.10 - Relação entre HPR e N

Figura 5.11 - Concentração dos sólidos suspensos voláteis (SSV) para $\mathrm{R}=0,25$ ( ), R=0,5

$(\triangleleft), \mathrm{R}=1,0(\Delta)$ e $\mathrm{R}=2,0$ ( $\square)$

Figura 5.12 - Geração de produtos intermediários $\left(\mathrm{C}_{\mathrm{PI}}\right)$ para $\mathrm{R}=0,25$ e $\mathrm{R}=0,5$ - ( $\Delta$ ) Ácido

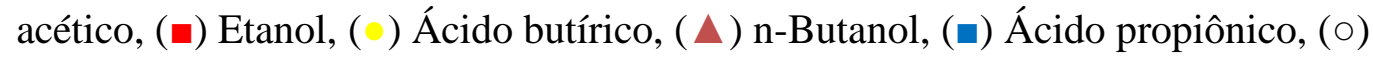
Acetona.

Figura 5.13 - Geração de produtos intermediários $\left(\mathrm{C}_{\mathrm{PI}}\right)$ para $\mathrm{R}=1,0$ e $\mathrm{R}=2,0$ - ( $\left.\mathbf{\Delta}\right)$ Ácido

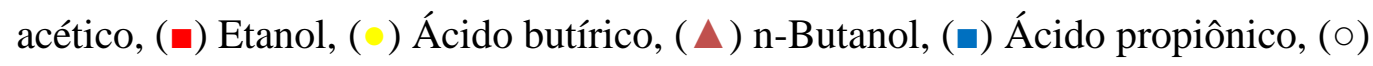
Acetona. 
Figura 5.14 - Concentração média dos produtos intermediários $\left(\mathrm{C}_{\mathrm{PI}}\right)$ gerados na fermentação do hidrogênio.

Figura 5.15 - Distribuição percentual média dos ácidos no meio líquido. .57

Figura 5.16 - Distribuição percentual média dos alcoois e acetona no meio líquido .58

Figura 5.17 - Eficiência de remoção de DQO para $R=0,25$ ( ), R=0,5 (•), R=1,0 ( $\Delta$ ) e $\mathrm{R}=2,0(\square)$

Figura 5.18 - Análise microscópica de amostras presentes em: (a) $R=0,25$; (b) $R=0,5$; (c) $\mathrm{R}=1,0$ e (d) $\mathrm{R}=2,0$

Figura 5.19 - pH no efluente dos reatores para $\mathrm{R}=0,25(\odot), \mathrm{R}=0,5(\diamond), \mathrm{R}=1,0(\Delta)$ e $\mathrm{R}=2,0$

$(\square)$.

Figura 5.20 - Pontos de coleta para os perfis espaciais .65

Figura 5.21 - Perfil espacial do pH nos reatores $\mathrm{R}=0,25(\bullet), \mathrm{R}=0,5(\diamond), \mathrm{R}=1,0(\Delta) \mathrm{e}$ $\mathrm{R}=2,0$

Figura 5.22 - Perfil espacial da eficiência de remoção de sacarose nos reatores $R=0,25$

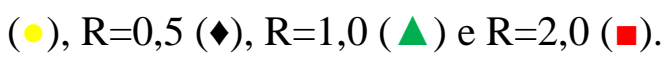

Figura 5.23 - Perfil espacial da geração de produtos intermediários $\left(\mathrm{C}_{\mathrm{PI}}\right)$ para $\mathrm{R}=0,25 \mathrm{e}$

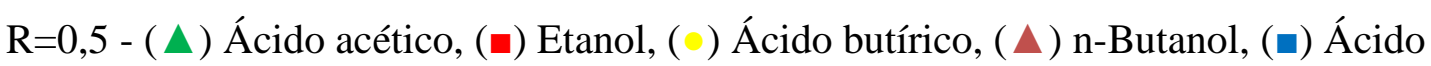
propiônico. .68

Figura 5.24 - Perfil espacial da geração de produtos intermediários $\left(\mathrm{C}_{\mathrm{PI}}\right)$ para $\mathrm{R}=1,0 \mathrm{e}$

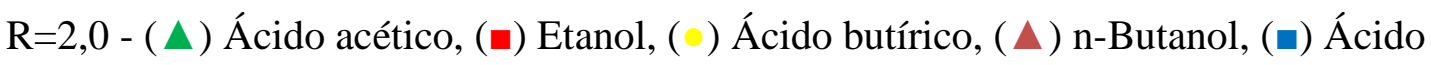
propiônico. .69

Figura 5.25 - Curvas de Distribuição do Tempo de Retenção (TDH) com e sem biomassa. ..70 


\section{LISTA DE TABELAS}

Tabela 3.1 - Rendimento máximo de açúcar a hidrogênio em processos fermentativos (Maintinguer, 2009) .8

Tabela 4.1 - Composição da água residuária sintética utilizada .22

Tabela 4.2 - Análises de monitoramento. .25

Tabela 5.1 - Dados obtidos nos ensaios hidrodinâmicos

Tabela 5.2 Valores médios e máximos da vazão de biogás produzido.

Tabela 5.3 - Valores médios de eficiência de remoção de sacarose.

Tabela 5.4 - Valores médios e máximos de eficiência de remoção de sacarose.

Tabela 5.5 - Resumo do teste ANOVA: Fator único para $\% H_{2}$

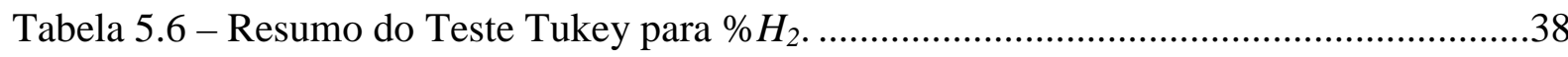

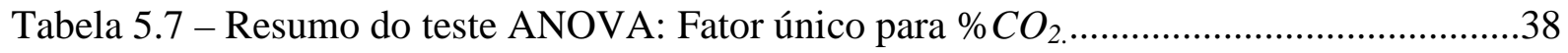

Tabela 5.8 - Vazão molar de hidrogênio $\left(v_{H 2}\right)$ para diferentes taxas de recirculação.

Tabela 5.9 - Resumo do teste ANOVA: Fator único para vazão molar de hidrogênio

$\left(v_{\mathrm{H} 2}\right)$.

Tabela 5.10 - Resumo do Teste Tukey para vazão molar de hidrogênio $\left(v_{\mathrm{H} 2}\right)$.

Tabela 5.11 - Rendimento de hidrogênio $\left(Y_{H_{2}}\right)$ para diferentes taxas de recirculação.

Tabela 5.12 - Resumo do teste ANOVA: Fator único para o rendimento de hidrogênio $\left(Y_{H 2}\right)$

Tabela 5.13 - Resumo do Teste Tukey para o rendimento de hidrogênio $\left(Y_{H 2}\right)$......

Tabela 5.14 - Produção volumétrica de hidrogênio (HPR) para diferentes taxas de recirculação.

Tabela 5.15 - Resumo do teste ANOVA: Fator único para a produção volumétrica de hidrogênio (HPR). .45

Tabela 5.16 - Resumo do Teste Tukey para a produção volumétrica de hidrogênio (HPR) ...46

Tabela 5.17 - Valores médios dos sólidos suspensos voláteis (SSV) no efluente dos reatores. 
Tabela 5.18 - Resumo do teste ANOVA: Fator único para a concentração dos sólidos suspensos voláteis (SSV)

Tabela 5.19 - Resumo do Teste Tukey para a concentração dos sólidos suspensos voláteis $(\mathrm{SSV})$

Tabela 5.20 - Concentração média dos produtos intermediários $\left(\mathrm{C}_{\mathrm{PI}}\right)$ gerados na fermentação do hidrogênio .55

Tabela 5.22 - Valores médios e máximos de eficiência de remoção de DQO. .60

Tabela 5.23 - Balanço da DQO efluente. 61

Tabela 5.24 - Valores médios e máximos do pH efluente. .64

Tabela 5.25 - Dados obtidos nos ensaios hidrodinâmicos. 71 


\section{LISTA DE SIMBOLOS}

$Q_{G} \quad$ Vazão de biogas

$v_{H 2} \quad$ Vazão molar de hidrogênio

$Y_{H 2}$ rendimento de hidrogênio

HPR Produção volumétrica de hidrogênio

R Razão de recirculação

$\mathrm{Q}_{\mathrm{R}} \quad$ vazão de recirculação da fase líquida

Q vazão de alimentação do reator

$\theta_{h} \quad$ Tempo de detenção hidráulica médio real

C Concentração do traçador

$\sigma^{2} \quad$ variância

$\delta_{\theta}^{2} \quad$ variância adimensional

$N \quad$ número de reatores

DQO Demanda Química de Oxigênio

SSV Sólidos Suspensos Voláteis

V volume útil do reator

$\theta$ tempo de detenção hidráulica médio teórico

$C_{S O} \quad$ concentração de sacarose no meio afluente

$C_{S F} \quad$ concentração de sacarose no efluente

$M M_{S} \quad$ massa molar da sacarose

$V_{m} \quad$ volume de gás obtido no medidor

$F_{m} \quad$ fator de calibração do medidor

$\%_{H 2}$ porcentagem de hidrogênio no biogás

$\%_{\mathrm{CO} 2}$ porcentagem de dióxido de carbono no biogás e metano

$\%_{\mathrm{CH} 4}$ porcentagem de metanono biogás 
$\eta_{H 2}$ número de mol de hidrogênio no biogás

$\eta_{\mathrm{CO} 2}$ número de mol de gás carbônico no biogás

$\eta_{\text {CH4 }}$ número de mol de metano no biogás

$\eta \quad$ número de mols totais na amostra de gás injetado

$P \quad$ pressão de gás

$V_{i} \quad$ volume de gás injetado

$R \quad$ constante universal dos gases ideais

$T \quad$ temperatura absoluta

$V_{\theta R} \quad$ volume útil do reator calculado com base nos tempos de detenção hidráulica reais obtidos nos ensaios hidrodinâmicos da primeira fase

$C_{P I} \quad$ Concentração dos produtos intermediários 


\section{INTRODUÇÃo}

O desenvolvimento da humanidade passou por um momento crítico com a Revolução Industrial em 1860. A substituição do trabalho humano e animal por fontes naturais de energia possibilitaram muitas vantagens para o Ser Humano. As vantagens obtidas com o uso dos combustíveis fósseis são indiscutíveis, com aumento da qualidade de vida e diminuição dos custos correspondentes. Porém, todo esse processo, feito de forma desestruturada, gerou problemas que começam a tomar proporções cada vez maiores. Os combustíveis fosseis são fontes não renováveis de energia, se tornando cada vez mais escassos. Além disso, seus produtos de combustão são responsáveis pelo crescente aquecimento global (Veziroglu; Sahin, 2008).

Devido a esses problemas, pesquisadores buscam possíveis fontes de energia para substituir os combustíveis fósseis. Entre as diversas fontes existentes pode-se destacar a energia termonuclear, energia solar, energia eólica, energia geotérmica, entre outras. O hidrogênio aparece como a melhor opção de combustível, por possuir características únicas em comparação com os outros combustíveis em questão (Veziroglu; Barbir, 1992).

O hidrogênio é um combustível limpo, pois gera, na sua combustão, água como produto e libera 2,75 vezes mais energia (calor de combustão) do que os hidrocarbonetos (Chen et al., 2001).

Apesar das vantagens, as principais dificuldades na utilização do hidrogênio como combustível são seu alto custo de produção e sua indisponibilidade na forma pura (Argun et al., 2008).

Cinquenta milhões de toneladas de hidrogênio são comercializadas no mundo, com taxa de crescimento de quase $10 \%$ por ano. Com base nas estimativas do programa nacional 
de hidrogênio dos Estados Unidos, a contribuição de hidrogênio para o mercado total de energia poderá ser aproximadamente 10\% para o ano 2025 (Argun et al. 2008; Oztekin et al. 2008). Atualmente, $40 \%$ do hidrogênio é produzido a partir de gás natural, $30 \%$ de óleos de alta densidade e da nafta, $8 \%$ a partir do carvão, $4 \%$ da eletrólise e $1 \%$ é produzido a partir de biomassa (Das, 2009).

A produção biológica de hidrogênio pode utilizar a fração orgânica presente nas águas residuárias. Este é um processo não agressivo ao meio ambiente, por não consumir combustíveis fósseis (Ren et al., 2007). A obtenção de hidrogênio por esse tipo de processo pode ocorrer de duas formas: fotossíntese e fermentação, sendo o último tecnicamente mais simples além de apresentar vantagens como alta velocidade de produção de hidrogênio, atuação de uma enzima, a hidrogenase, que não requer suprimento direto de ATP e baixos custos (Hawkes et al., 2002). Uma grande vantagem nos tratamentos anaeróbios é que os poluentes orgânicos são convertidos em hidrogênio, formando ao mesmo tempo ácidos orgânicos e solventes que também podem ter valor comercial (Cheong; Hansen, 2007).

O presente trabalho buscou dar continuidade a linha de pesquisa desenvolvida no LPB (Laboratório de Processos Biológicos - EESC/USP) para produção de hidrogênio em reatores anaeróbios (Fernandes, 2008; Peixoto, 2008; Rojas, 2010), com o estudo do efeito do grau de mistura em reator anaeróbio de leito fixo sobre a produção de hidrogênio, mediante recirculação do efluente. A introdução de uma recirculação no sistema poderia levar a efeitos positivos e negativos para a produção de hidrogênio, o que sugere uma razão de recirculação ótima. Teoricamente, com o aumento do grau de mistura, deverá ocorrer uma melhor transferência de massa da fase líquida para o biofilme, melhorando as velocidades de conversão do substrato, e da fase líquida para a gasosa, permitindo maior liberação do hidrogênio produzido. No entanto, teoricamente, a introdução da recirculação do meio líquido tende a levar a valores menores de eficiência pelo aumento do grau de mistura e 
distanciamento do escoamento pistonado. Dessa forma, buscou-se, com o presente trabalho, encontrar uma razão de recirculação adequada para uma produção significativa e estável de hidrogênio em reatores de leito fixo, tendo em vista que não existem trabalhos científicos que abordem o tema. 


\section{OBJETIVOS}

\subsection{Objetivo geral}

O principal objetivo do presente trabalho foi avaliar a influência do grau de mistura na produção biológica do gás hidrogênio em reator anaeróbio de leito fixo e fluxo ascendente alimentado com meio sintético a base de sacarose.

\subsection{Objetivos específicos}

Os objetivos específicos do trabalho foram:

- Avaliar a produção volumétrica, o rendimento e a velocidade de produção do gás hidrogênio para diferentes graus de mistura;

- Determinar o percentual do gás hidrogênio na composição do biogás produzido, a distribuição de ácidos voláteis e álcoois produzidos, bem como a remoção de matéria orgânica em cada grau de mistura. 


\section{REVISÃO DA LITERATURA}

\subsection{Hidrogênio}

O hidrogênio é o elemento mais abundante existente na Terra, podendo ser encontrado combinado com outros elementos. Entre os compostos formados por essa combinação, o de maior destaque para a vida no planeta é a água. O hidrogênio pode ser encontrado em todos os componentes da matéria viva e de muitos minerais e faz parte de ácidos, hidrocarbonetos e muitas outras substâncias orgânicas (Das \& Veziroglu, 2001).

O hidrogênio pode ser utilizado como combustível em motores de foguetes, como refrigerante em geradores elétricos e, como vem sendo extensivamente estudado atualmente, como fonte de energia renovável (van Ginkel \& Sung, 2001; Lee et al, 2003; Leite et al, 2008).

Em comparação com demais alternativas aos combustíveis fósseis, o hidrogênio se apresenta como a melhor opção. Ele é o combustível que apresenta melhor facilidade de transporte, que apresenta melhor versatilidade, melhor eficiência e que apresenta melhor segurança. Em resumo, é o melhor combustível (Veziroglu \& Sahin, 2008).

\subsection{Métodos de produção de hidrogênio}

Atualmente existem alguns métodos que se destacam para produção de hidrogênio: a partir de combustíveis fósseis, biomassa e água. Os métodos a partir de combustíveis fósseis são a reforma do vapor do gás natural, cracking térmico do gás natural, oxidação parcial da nafta e gaseificação do carvão. Os métodos a partir da biomassa são a pirólise e a gasificação. Por último, os métodos a partir da água são a eletrólise, a fotólise, processos termoquímicos, 
decomposição térmica direta (termólise) e produção biológica (Das \& Veziroglu, 2001). Este último receberá maior destaque, pois foi utilizado nessa pesquisa.

\subsection{Produção biológica de hidrogênio}

A produção biológica de hidrogênio tem se destacado por se apresentar como uma alternativa menos agressiva ao ambiente, utilizando matérias primas renováveis no processo, conferindo-lhe a grande vantagem de ser independente dos combustíveis fósseis. Atualmente, 96\% do hidrogênio produzido no mundo são derivados de combustíveis fósseis, o que não resolve o problema de substituição destes. Diversas pesquisas estão, por isso, sendo desenvolvidas em âmbito mundial explorando a produção biológica de hidrogênio (Vijayaraghavan \& Soom, 2004).

A produção biológica de hidrogênio pode ocorrer por meio de dois processos: fotossíntese e fermentação. A produção biológica de hidrogênio pela etapa fermentativa da digestão anaeróbia é mais simples, pois o hidrogênio juntamente com ácidos voláteis e álcoois são obtidos principalmente de carboidratos presentes em águas residuárias, não necessita de luz nem de culturas puras e os custos de operação são relativamente baixos (Han \& Shin, 2004, Alzate et al, 2007; Ren et al, 2007; Lin \& Lay, 2004; Fernandes, 2008; Ntaikou, 2008). Além disso, os ácidos produzidos (principalmente butírico, acético e propiônico) podem ser usados por indústrias químicas e de alimentos (Leite et al., 2008). Na Tabela 3.1 são apresentados os rendimentos máximos de conversão de açúcares a hidrogênio nos processos fermentativos. 
Tabela 3.1 - Rendimento máximo de açúcar a hidrogênio em processos fermentativos (Maintinguer, 2009)

\begin{tabular}{|c|c|c|}
\hline Açúcar & Rota metabólica & Mol H2. mol açúcar \\
\hline \multirow{2}{*}{ Glicose } & $\begin{array}{c}\mathrm{C}_{6} \mathrm{H}_{12} \mathrm{O}_{6}+2 \mathrm{H}_{2} \mathrm{O} \rightarrow 2 \mathrm{CH}_{3} \mathrm{COOH}(\text { ac. } \\
\text { acético })+2 \mathrm{CO}_{2}+4 \mathrm{H}_{2}\end{array}$ & 4 \\
\hline & $\begin{array}{c}\mathrm{C}_{6} \mathrm{H}_{12} \mathrm{O}_{6} \underset{\mathrm{CH}_{3} \mathrm{CH}_{2} \mathrm{CH}_{2} \mathrm{COOH}(\text { ac. }}{\rightarrow \text { butírico })+2 \mathrm{CO}_{2}+2 \mathrm{H}_{2}}\end{array}$ & 2 \\
\hline \multirow[b]{2}{*}{ Sacarose } & $\begin{array}{c}\mathrm{C}_{12} \mathrm{H}_{22} \mathrm{O}_{11}+5 \mathrm{H}_{2} \mathrm{O} \rightarrow 4 \mathrm{CH}_{3} \mathrm{COOH}(\text { ac. } \\
\text { acético })+4 \mathrm{CO}_{2}+8 \mathrm{H}_{2}\end{array}$ & 8 \\
\hline & $\begin{array}{c}\mathrm{C}_{12} \mathrm{H}_{22} \mathrm{O}_{11}+2 \mathrm{H}_{2} \mathrm{O} \rightarrow \\
2 \mathrm{CH}_{3} \mathrm{CH}_{2} \mathrm{CH}_{2} \mathrm{COOH}(\text { ac. butírico })+ \\
4 \mathrm{CO}_{2}+4 \mathrm{H}_{2}\end{array}$ & 4 \\
\hline \multirow[b]{2}{*}{ Xilose } & $\begin{array}{c}\mathrm{C}_{5} \mathrm{H}_{10} \mathrm{O}_{5}+3 \mathrm{H}_{2} \mathrm{O} \rightarrow \mathrm{CH}_{3} \mathrm{COOH}(\text { ac. } \\
\text { acético })+3 \mathrm{CO}_{2}+6 \mathrm{H}_{2}\end{array}$ & 6 \\
\hline & $\begin{array}{c}\mathrm{C}_{5} \mathrm{H}_{10} \mathrm{O}_{5}+2 \mathrm{H}_{2} \mathrm{O} \rightarrow \\
1 / 2 \mathrm{CH}_{3} \mathrm{CH}_{2} \mathrm{CH}_{2} \mathrm{COOH}(\text { ac. butírico })+ \\
3 \mathrm{CO}_{2}+5 \mathrm{H}_{2}\end{array}$ & 5 \\
\hline
\end{tabular}

De acordo com Speece (1996), a digestão anaeróbia é um processo complexo que envolve diversos tipos de bactérias e fases intermediárias. Os componentes orgânicos complexos (polímeros) contidos no substrato são hidrolisados em compostos mais simples (monômeros). Estes são metabolizados pelas bactérias fermentativas, sendo convertidos em ácidos voláteis, álcoois, gás carbônico, hidrogênio, amônio/amônia e sulfeto. Os ácidos voláteis com mais de dois carbonos são convertidos em acetato e gás hidrogênio pelas bactérias acetogênicas. Por último, o acetato e o gás hidrogênio são convertidos em metano pelas arqueias metanogênicas acetoclásticas ou hidrogenotróficas, respectivamente.

Quando existem sulfato e nitrato presentes no meio, as bactérias redutoras de sulfato e as bactérias redutoras de nitrato são capazes de utilizar o hidrogênio como doador de elétrons, formando sulfeto e amônia, respectivamente (Valdez-Vazquez et al, 2005).

O processo anaeróbio de conversão da matéria orgânica está esquematizado de forma simplificada na Figura 3.1. 


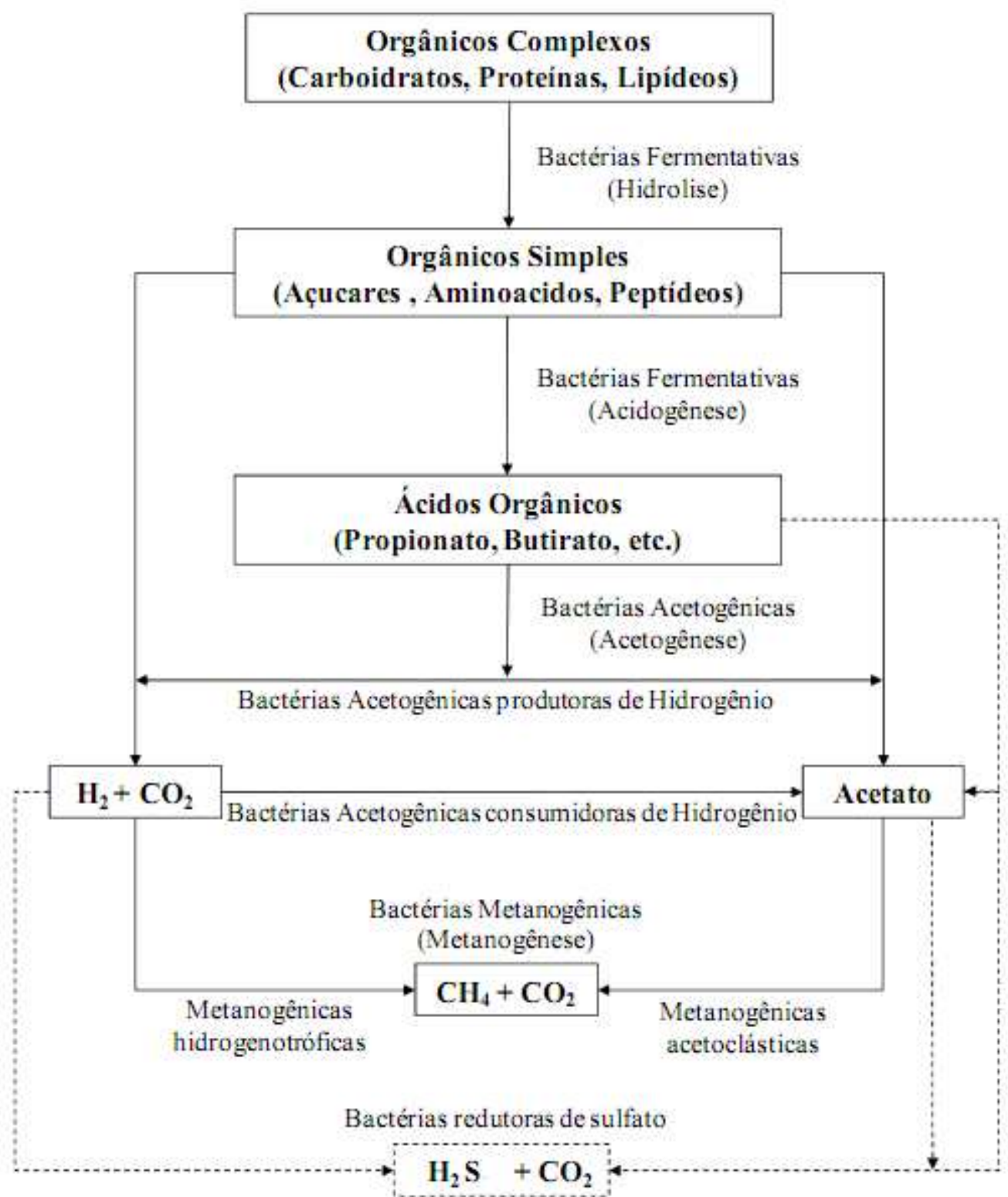

Figura 3.1 - Processo de conversão anaeróbia da matéria orgânica (Chernicharo, 1997; Speece, 1996).

\subsection{Produção de hidrogênio em reatores anaeróbios}

O processo de digestão anaeróbia pode ser dividido resumidamente em duas etapas, a acidogênese a metanogênese. A obtenção de hidrogênio se torna possível se o processo for interrompido na primeira etapa. A acumulação de hidrogênio é devida ao desequilíbrio entre as bactérias produtoras de hidrogênio e consumidoras como as arqueias metanogênicas e, eventualmente, redutoras de sulfato e nitrato, o que torna necessário que exista um 
desequilíbrio entre produtoras e consumidoras, com predominância das primeiras (Leite et al, 2008).

Para otimizar o processo de produção de hidrogênio, existem diversas estratégias de controle operacional nos reatores. Estas serão descritas a seguir.

\subsubsection{Influência do TDH (Tempo de Detenção Hidráulica)}

Baixos tempos de detenção hidráulica (TDH) podem ser utilizados para selecionar os microrganismos produtores de hidrogênio tendo em vista que a velocidade de crescimento específica das metanogênicas (consumidoras de hidrogênio) é muito menor do que a velocidade de crescimento das bactérias produtoras de hidrogênio $\left(0,0167\right.$ e $0,083 \mathrm{~h}^{-1}$, respectivamente) (Chen et al, 2001). Diversos autores comprovaram que a aplicação de baixos TDH resulta em maiores velocidades de produção de $\mathrm{H}_{2}$. Lee et al. (2003) obtiveram uma velocidade máxima de produção em TDH de $0,5 \mathrm{~h}$, quando operaram reator com TDH entre 0,5 e 4 h. Chang et al. (2008) operaram um reator com TDH entre 12 e 3 horas, obtendo maiores taxas de produção de $\mathrm{H}_{2}$ para o TDH de 3 horas.

\subsubsection{Influência do $\mathrm{pH}$}

$\mathrm{O}$ pH é um parâmetro fundamental nos reatores anaeróbios que pode influenciar na produção de hidrogênio e inibir a ação de microrganismos hidrogenotróficos. Controlando o $\mathrm{pH}$, é possível inativar esses microrganismos, mesmo que o sistema apresente condições favoráveis para o aparecimento destes (Cheng et al., 2008).

Pesquisas mostram que o pH ótimo para produção de hidrogênio está na faixa entre 5,0 e 6,5 (Fang et al., 2002; Lin \& Chang, 2004).Outras pesquisas apontam um valor único como ótimo, de 5,5 (Liu \& Fang, 2002; Mu et al., 2007; Shin, 2007). 
É importante destacar que um pH abaixo de 4,5 é desfavorável para a produção de hidrogênio, tendo em vista que nessas condições ocorre a inibição da atividade da hidrogenase e de outras enzimas envolvidas no processo de produção de hidrogênio (Lay et al., 1999).

\subsubsection{Influência da temperatura}

Estudos relacionados com o efeito da temperatura na digestão anaeróbia mostram um efeito negativo na atividade metabólica dos microrganismos anaeróbios com a diminuição da temperatura. Quanto maior a temperatura, de uma forma geral, maior será a atividade microbiana até que seja atingida uma temperatura ótima. Os microorganismos são classificados em algumas categorias de temperaturas, baseadas na faixa de temperatura que estes conseguem se desenvolver (psicrofílicos, mesofílicos e termofílicos). Variações significativas de temperatura devem ser previstas no tratamento de águas residuárias e o projeto deve fornecer flexibilidade suficiente para garantir a estabilidade do processo (Lettinga et al., 2001).

A temperatura tem uma influência importante na produção de hidrogênio. Na faixa entre $25^{\circ} \mathrm{C}$ e $40^{\circ} \mathrm{C}$ ocorrem as melhores eficiências do processo, principalmente em condições próximas da ideal $\left(35^{\circ} \mathrm{C}\right)$ para funcionamento dos catalisadores bioquímicos (Zhang \& Shen, 2005).

Muitas pesquisas convergem para valores de temperaturas que variam entre $30^{\circ} \mathrm{C}$ e $36,8^{\circ} \mathrm{C}$, definindo estas como temperaturas ótimas para sistemas anaeróbios fermentativos produtores de hidrogênio (Fang et al., 2002; Lin \& Chang, 2004; Mizuno et al., 2002). 


\subsubsection{Influência do inóculo}

O inóculo possui um importante papel na produção de hidrogênio, de acordo com Kawagoshi et al. (2005). No estudo realizado por esses autores, demonstrou-se que em meios iguais, com a mesma concentração de substrato e mesma condição nutricional, houve variação na produção de hidrogênio de $0,15 \mathrm{~mol} \mathrm{H} \cdot \mathrm{mol}^{-1}$ de glicose (inóculo proveniente de lodos ativados) a 1,35 mol $\mathrm{H}_{2} \cdot \mathrm{mol}^{-1}$ de glicose (inóculo proveniente de lodo anaeróbio digerido).

É possível empregar microrganismos para produzir hidrogênio tanto em culturas puras (Shin et al., 2007; Liu et al., 2006) quanto em culturas mistas (Oh et al., 2003; Han \& Shin, 2004). O uso de culturas mistas apresenta vantagens com relação a possíveis aumentos de escala dos reatores: geração contínua de $\mathrm{H}_{2}$, geração de metabolitos de interesse comercial (ácidos orgânicos e solventes) e possibilidade de utilização de compostos orgânicos complexos como substrato em condições não estéreis (Das \& Veziroglu, 2001; Levin et al., 2004; Liang et al., 2002)

\subsubsection{Influência do substrato}

Os estudos desenvolvidos para produção de $\mathrm{H}_{2}$, em sua maior parte, utilizam afluentes sintéticos que contém sacarose como fonte de carbono orgânico e suplementação inorgânica balanceada baseada nas formulações usadas no trabalho de Bahl et al. (1982) ou no estudo desenvolvido por Endo et al. (1982). Estudos também foram realizados testando efluentes mais complexos, como celulose, pentose e xilose (Rogers \& Gottschalk, 1993; Taguchi et al., 1995).

Diferentes águas residuárias são utilizadas como substrato para a produção de biohidrogênio, nas quais a fonte de matéria orgânica carbonácea pode ser sacarose, glicose, amido de trigo, fração orgânica de resíduos sólidos, efluente de reatores biológicos, óleos 
vegetais, resíduos da produção de biodiesel e efluente da indústria de laticínios, especificamente o soro de leite. O objetivo comum de tais estudos tem sido a avaliação da produtividade em hidrogênio e da estabilidade operacional (Lin e Lay, 2004, 2005; Ito et al., 2005; Alzate et al, 2007; Jeong et al., 2007; Nishio e Nakashimada, 2007; Yang et al., 2008; Argun et al., 2008; O-Thong et al., 2008; Oztekin et al., 2008; Sabourin-Provost et al., 2009; Fernandes, 2008; Amorim, 2009; Barros, 2009; Reis, 2010). Além disso, tem sido investigada a melhoria da composição das águas residuárias em termos do equilíbrio de nutrientes no intuito de possibilitar acréscimo de produtividade em hidrogênio e, assim, otimizar a aplicação desses diversos efluentes (Lin e Lay, 2005; Argun et al., 2008; Turcot et al., 2008; Peixoto, 2008; Rojas, 2010).

\subsubsection{Influência da configuração do reator}

Muitas configurações de reatores foram testadas para produção de hidrogênio: reatores de leito fixo (Chang et al., 2002; Lee et al., 2003; Leite et al., 2008; Fernandes, 2008; Peixoto, 2008; Rojas, 2010), reatores de manta de lodo (UASB) (Chang \& Lin, 2004; Huang et al., 2004; Mohan et al., 2008), reatores de leito fluidizado (Wu et al., 2003; Amorim, 2009; Barros, 2009; Reis, 2010), reatores em batelada (Arooj et al., 2007; Cheong et al., 2007), reatores contínuos com agitação (Lin \& Lay, 2005; Siriwongrungson et al., 2007).

Muitos autores buscaram comparar configurações de reatores com o intuito de encontrar qual teria melhor eficiência de produção de hidrogênio. Alzate-Gaviria et al. (2007) descreveram que reatores de fluxo contínuo apresentam maiores níveis e constância na produção de hidrogênio. Li et al. (2007) estudaram a produção de hidrogênio em reatores em batelada e contínuos com agitação, observando que o reator em batelada apresentou maior estabilidade de produção de $\mathrm{H}_{2}$ e melhor atividade microbiana. 
Em seus estudos, Wu et al. (2002) compararam a produção de hidrogênio em reatores com células suspensas e com células imobilizadas em diversos suportes. Os autores observaram que a produção de hidrogênio foi maior nos reatores com células aderidas, com os reatores com células suspensas apresentando os piores resultados. De acordo com os autores, a produção biológica de hidrogênio em sistemas com células suspensas geralmente é ineficiente para reatores contínuos, pois apresenta problemas com o reciclo da biomassa, dificultando a obtenção de concentração celular suficiente para obtenção de alta produção de hidrogênio.

Lee et al. (2003) utilizaram reatores com leito empacotado aplicando como material suporte carvão ativado para produção anaeróbia de hidrogênio a partir de sacarose e utilizando como inóculo lodo de esgoto. Avaliou-se a produção de hidrogênio mediante o efeito da porosidade e do tempo de detenção hidráulica (TDH) e observou-se que a produção de hidrogênio é favorecida tanto pela eficiência de imobilização da biomassa em leitos fixos quanto pela manutenção de uma alta porosidade nos mesmos. Resultados similares foram obtidos por Fernandes (2008) em sua pesquisa.

No LPB, além de Fernandes (2008), também podem ser destacados os trabalhos de Peixoto (2008) e Rojas (2010), que estudaram a produção de hidrogênio em reatores de leito fixo variando parâmetros operacionais..

\subsubsection{Influência do grau de mistura}

Estudos realizados por Pauss et al. (1990) confirmaram a existência de baixos coeficientes de transferência de massa e conseqüentemente uma alta concentração de hidrogênio e metano dissolvidos (cerca de 70 e 12 vezes os valores no equilíbrio, respectivamente) em reatores biológicos. Neste estudo, os reatores com mistura apresentaram as melhores eficiências de transferência. Uma forma de obter essa mistura em reatores é recirculando o efluente.

A recirculação apresenta como finalidade a homogeneização do meio e, conseqüentemente, o aumento da velocidade de transferência de massa (Aiba, 1971). O 
aumento da recirculação aumenta a velocidade do líquido no reator e conseqüentemente melhora a transferência de massa do estado líquido para o estado gasoso. Isto provoca uma maior liberação do hidrogênio produzido no meio líquido para o meio gasoso. Lamed et al. (1988) sugeriram que a saturação de hidrogênio no meio líquido atua de maneira importante na produção de intermediários. Com a recirculação, ocorreria uma liberação desse hidrogênio em excesso no meio líquido, diminuindo possíveis inibições causadas por altas concentrações de $\mathrm{H}_{2}$ no meio. Soma-se a isso o fato que com a melhoria da transferência de massa, ocorre uma melhoria na transferência do meio líquido para a biomassa, ocorrendo assim uma melhor degradação do substrato e melhor produção de hidrogênio.

O emprego de recirculação em reatores com biomassa imobilizada diminui as zonas com menor contribuição nos processos de difusão e transferência de massa, facilitando a distribuição espacial uniforme da carga. Outro fato importante é que diluir a alimentação reduz os efeitos de variação de carga afluente e dos compostos tóxicos e inibidores (Horváth, 1994; Narayanan, 1995; Von Sperling, 1996).

A recirculação, porém, pode trazer efeitos negativos. De acordo com Levenspiel (2000), regimes hidrodinâmicos de mistura completa (que podem ocorrer com altas razões de recirculação) inibem a formação de todos os intermediários das reações processadas, enquanto que regimes hidrodinâmicos pistonados (que podem ocorrer em sistemas sem recirculação) fornecem a maioria destes produtos intermediários das reações envolvidas. Outro fator negativo na recirculação é a necessidade de utilização de bombas, implicando em gastos com energia (Sreekrishan et al., 1991; Romli et al., 1994). Com isso, é necessário reduzir a recirculação ao menor valor possível. 


\subsection{Microbiologia da produção de hidrogênio}

Existem diversos microrganismos com a capacidade de produzir hidrogênio. Estes podem ser termofílicos ou mesofílicos, anaeróbios ou facultativos, desde que possuam enzimas hidrogenase ou nitrogenase. Como exemplos desses microrganismos podem citar Clostridia, Rumen bactéria, Thermoanaerobacter, Enterobacter, Escheicchia Coli, Citrobacter, Methanosarcina barkeri (Reith et al., 2003). Vijayaraghavan e Soom (2004) apontam como as principais bactérias produtoras de hidrogênio: Enterobacter aerogenes, Enterobacter cloacae, Clostridium butyricum, Clostridium pasteurianum, Desulfovibrio vulgaris, Magashaera elsdenii, Citrobacter intermedius e Escherichia coli. Existem ainda os fungos, que também possuem enzimas hidrogenase e consequentemente são capazes de produzir hidrogênio, embora sejam pouco utilizados para essa finalidade (Boxma, 2005).

Os microrganismos pertencentes aos gêneros Clostridium são os mais importantes devido a seu alto potencial para produção de hidrogênio, pelo seu rápido metabolismo e sua capacidade de formar esporos. Esses organismos são capazes de produzir hidrogênio em condições mesofílicas ou termofílicas dentro de uma faixa de pH entre 5 e 6 (Krupp e Widmann, 2009). De acordo com Hawkes et al. (2002), o rendimento de hidrogênio a partir de espécies de Clostridium é geralmente maior do que aquele obtido por bactérias aeróbias facultativas como Enterobacter sp. Em seus estudos, Lay (2001) determinou que o gênero Clostridium é o produtor de hidrogênio predominante.

Em processos anaeróbios, o hidrogênio é produzido durante a fase exponencial de crescimento do Clostridium, com produção de solventes na fase estacionária. Isso acontece quando o pH cai para menos de 4,5. Aparentemente, o acúmulo de ácidos graxos voláteis e hidrogênio na fase de crescimento exponencial provocam essa mudança de rota. Os gêneros Clostridium podem produzir hidrogênio a partir da degradação de proteínas, aminoácidos ou carboidratos. O Clostridium. acetobutyricum tem despertado grande interesse devido à sua 
capacidade de fermentar vários substratos em valiosos produtos finais como acetona, butanol e etanol (Mathews e Wang, 2009).

\subsection{Considerações finais}

A produção biológica de hidrogênio tem se mostrado uma alternativa interessante por disponibilizar um combustível limpo e ao mesmo tempo tratar efluentes. Por ser um tema relativamente novo, os trabalhos disponíveis são poucos, a maior parte abordando trabalhos em batelada típica.

Seguindo uma linha de pesquisa realizada no Laboratório de Processos Biológicos (LPB) da Escola de Engenharia de São Carlos (EESC)/USP, o presente trabalho procurou analisar o efeito da recirculação em reatores contínuos na produção de hidrogênio, tema este que apresenta poucos trabalhos disponíveis na literatura especializada. 


\section{MATERIAL E MÉTODOS}

Os experimentos foram realizados com o intuito de comparar a influência de diferentes razões de recirculação $(\mathrm{R})$ na produção de hidrogênio em reator de leito fixo. A razão de recirculação $(R)$ é definida como a relação entre a vazão de recirculação da fase líquida $\left(Q_{R}\right)$ e a vazão de alimentação do reator $(\mathrm{Q})$, sendo:

$$
R=\frac{Q_{R}}{Q}
$$

Na primeira fase foram realizados ensaios hidrodinâmicos para definir quais vazões seriam utilizadas na segunda e terceira fases. Nestas foram operados dois reatores simultaneamente, cada um com uma razão de recirculação diferente. A Figura 4.1 apresenta um esquema geral dos experimentos realizados. 


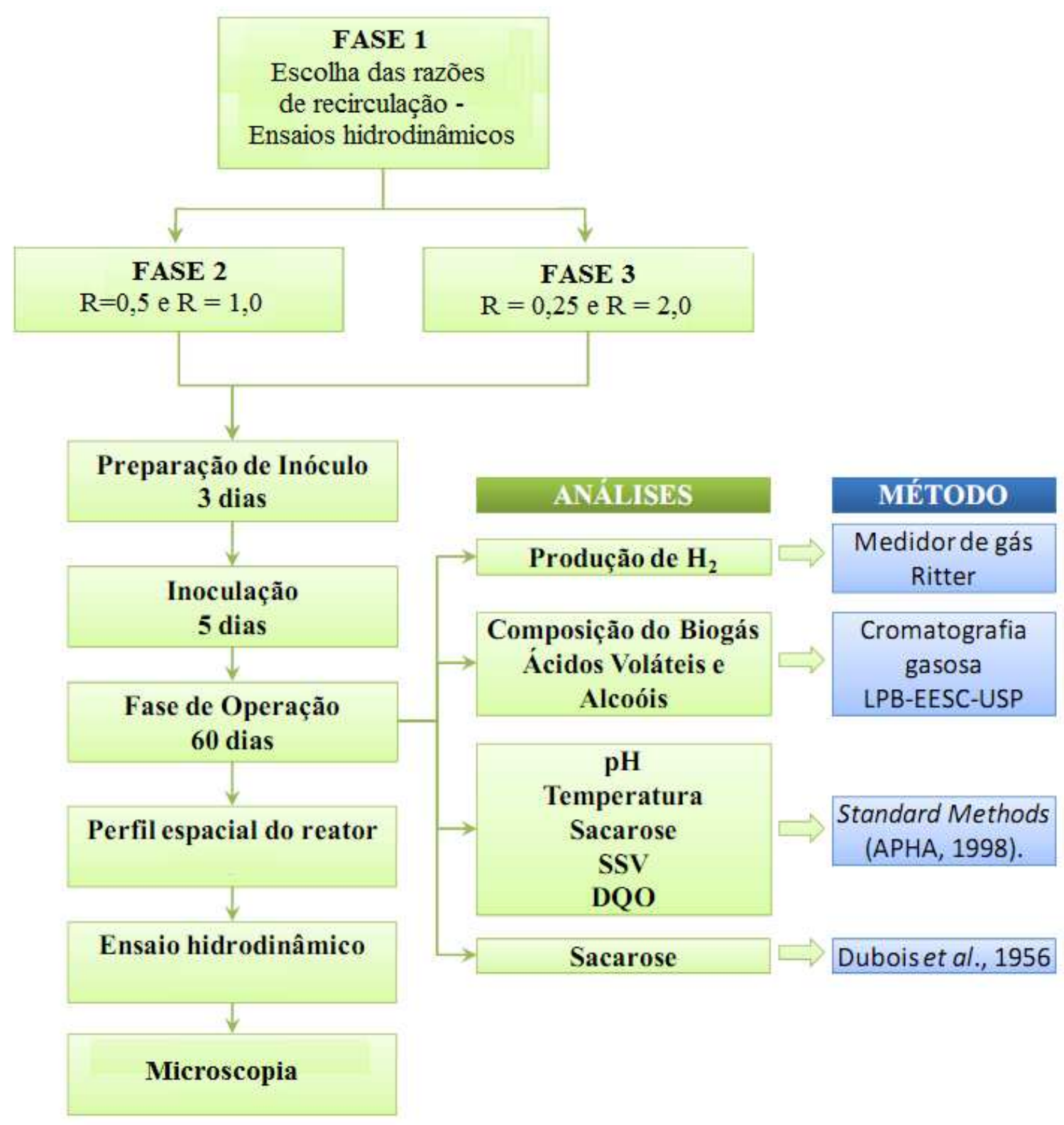

Figura 4.1 - Esquema geral dos experimentos realizados

\subsection{Reatores}

O estudo foi realizado em dois reatores anaeróbios de leito fixo e fluxo ascendente, em escala de bancada. Os reatores apresentaram a seguinte configuração: tubos de acrílico com diâmetro interno de $80 \mathrm{~mm}$, diâmetro externo de $88 \mathrm{~mm}$ e $750 \mathrm{~mm}$ de comprimento, com um volume de leito de 2,5 litros e um volume total de 3,5 litros. Cada reator foi dividido em três compartimentos: entrada do efluente, saída do efluente e leito, separados por telas de aço 
inoxidável (5 $\mathrm{mm}$ de abertura), fixadas por hastes de $5 \mathrm{~mm}$ do mesmo material. As dimensões adotadas estavam de acordo com trabalhos realizados no Laboratório de Processos Biológicos (LPB) da Escola de Engenharia de São Carlos (EESC) da Universidade de São Paulo (USP) por Fernandes (2008), Peixoto (2008) e Rojas (2010).

O leito apresentou comprimento de $50 \mathrm{~cm}$ e cinco pontos de amostragem igualmente espaçados para coleta de dados de concentração em função do comprimento. Existiam, ainda, dois pontos, um no compartimento de entrada do afluente e outro no compartimento de saída do efluente, para que possa ser realizada a recirculação do efluente. Esta era feita através de mangueiras de silicone curtas e com isso o volume líquido fora do reator era desprezível em relação ao volume líquido dentro do reator. A parte superior do leito foi vedada para evitar possíveis vazamentos de gases e apresentando tubo em "L" com a extremidade apontada para o sentido oposto do fluxo gasoso e do líquido. O estudo foi realizado em dois reatores idênticos apresentados na Figura 4.2.
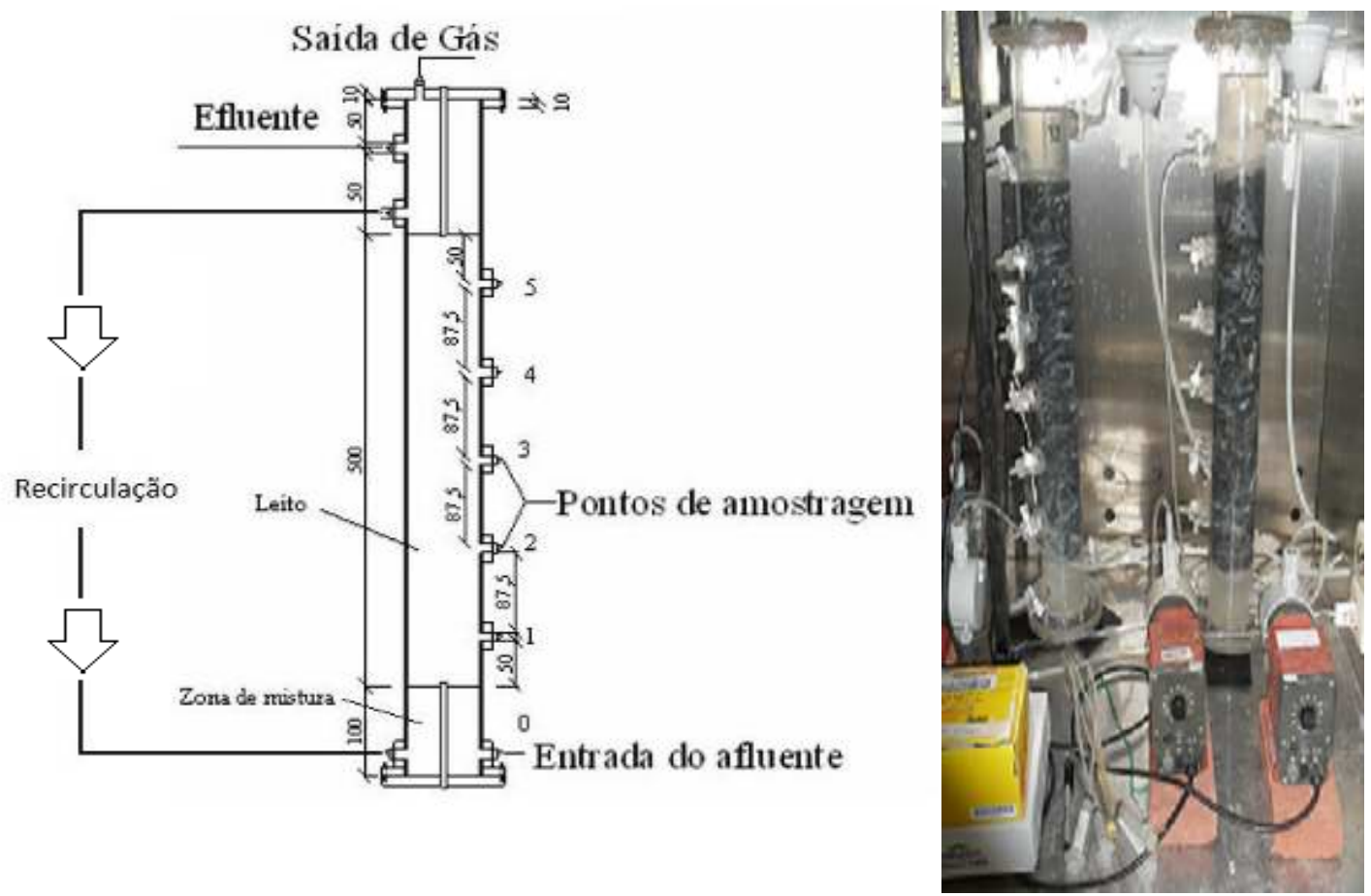

Figura 4.2 - Aparato experimental para produção de hidrogênio 


\subsection{Meio suporte}

O meio suporte utilizado para imobilização da biomassa foi polietileno de baixa densidade obtido como apara de usina de reciclagem de plástico, de acordo com os trabalhos de Fernandes (2008), Peixoto (2008) e Rojas (2010).

\subsection{Meio de alimentação}

Os reatores usados no estudo foram alimentados com afluente preparado sinteticamente à base de sacarose (Tabela 4.1). O requerimento de carbono foi disponibilizado pela sacarose e o nitrogênio na forma de uréia, utilizando a melhor relação $\mathrm{C} / \mathrm{N}$ encontrada por Rojas (2010), de 140. A DQO da água residuária sintética foi igual a $2000 \mathrm{mg} . \mathrm{L}^{-1}$. Além disso, bicarbonato de sódio $\left(500 \mathrm{mg} . \mathrm{L}^{-1}\right)$ e ácido clorídrico $\left(0,45 \mathrm{ml}\right.$ de ácido. $\left.\mathrm{L}^{-1}-10 \mathrm{~mol} . \mathrm{L}^{-1}\right)$ foram adicionados para ajustar o $\mathrm{pH}$ de entrada em 6,5, tendo em vista que trabalhos realizados no LPB por Fernandes (2008) e Peixoto (2008) indicam que este é reduzido a 5,5 logo na entrada do afluente do reator, sendo este último valor o mais apropriado para produção de hidrogênio. 
Tabela 4.1 - Composição da água residuária sintética utilizada

(adaptação do meio Del Nery, 1987)

COMPOSTO CONCENTRAÇÃO $\left(\mathrm{mg}^{-\mathrm{L}^{-1}}\right)$

Sacarose 1781,24

Uréia 11,50

Sulfato de níquel 0,50

Sulfato ferroso 2,50

Cloreto férrico 0,25

Cloreto de cálcio 2,06

Cloreto de cobalto 0,040

Óxido de selênio 0,036

Fosfato de potássio monobásico 5,36

Fosfato de potássio dibásico

Fosfato de sódio dibásico

\subsection{Inoculação}

O inóculo foi obtido pelo processo de fermentação natural do meio de alimentação, preparado com água de abastecimento e mantido em repouso durante três dias, em recipiente aberto. Esse processo favorece a fermentação do meio através de microrganismos presentes na atmosfera e provenientes da água de abastecimento utilizada (Leite et al., 2008). Além disso, parte do inóculo foi obtido dos microrganismos presentes no material suporte, que não foi esterilizado. 


\subsection{Procedimento experimental - operação dos reatores e ensaios hidrodinâmicos}

A produção de hidrogênio foi avaliada para quatro razões de recirculação diferentes. Estas razões utilizadas foram determinadas a partir de ensaios hidrodinâmicos (fase 1). O traçador utilizado foi dextrana azul aplicado ao reator na forma de pulso (Levenspiel, 2000).

Após os ensaios hidrodinâmicos iniciais para determinação dos valores das razões de recirculação que seriam aplicadas, o experimento foi realizado em duas etapas. Em cada etapa foram testadas duas razões de recirculação, uma em cada reator. Cada etapa teve duração de 60 dias, com base em trabalhos anteriores (Rojas, 2010). Na segunda fase foram testadas as condições de $\mathrm{R}$ iguais a 0,5 e 1,0 e, na terceira fase, as razões de recirculação aplicadas foram de 0,25 e 2,0 .

Em todas as etapas o sistema foi operado em modo contínuo à temperatura controlada de $25^{\circ} \mathrm{C}$ por meio de câmara climatizada. O tempo de detenção hidráulica teórico (TDH) aplicado foi de 2 horas, de acordo com trabalhos realizados no LPB (Fernandes, 2008; Peixoto, 2008; Rojas, 2010). De posse desse valor e com o volume útil do reator (obtido enchendo o reator, já com o material suporte, com água) calculou-se a vazão a ser aplicada (21 mL/min) para alimentação e para o cálculo das razões de recirculação. O afluente passava primeiro por um reservatório e depois era recalcado para o reator, cujo leito ficava submetido ao fluxo ascendente do substrato.

Foram realizados estudos hidrodinâmicos nos reatores tanto utilizando apenas água na alimentação, com a finalidade de escolher a faixa dos valores de razão de recirculação que foram utilizados, quanto no final de cada operação, para avaliar as mudanças nas características do padrão de escoamento com o acúmulo de biomassa. O TDH teórico aplicado foi de $2 \mathrm{~h}$ (obtido com uma vazão de $21 \mathrm{~mL} / \mathrm{min}$ ) e utilizou-se dextrana azul como traçador, o qual foi aplicado nos reatores na forma de pulso segundo a metodologia de Levenspiel (2000). Para os reatores vazios, foram utilizadas as seguintes razões de 
recirculação: $\mathrm{R}=0,0,25,0,5,1,0,2,0$ e 3,0. Para os reatores com biomassa no final de cada operação, foram utilizadas as seguintes razões (que foram as de operação escolhidas): $\mathrm{R}=0,25$, $\mathrm{R}=0,5, \mathrm{R}=1,0$ e $\mathrm{R}=2,0$.

O reator foi alimentado com água do sistema público de abastecimento e foi dado um pulso de $50 \mathrm{~mL}$ de uma solução do traçador (concentração de $2 \mathrm{mg}$ de dextrana azul/L). As amostras foram coletadas na saída do reator de 3 em 3 minutos durante 3 h (1,5 vez o TDH teórico) e depois foram lidas em espectrofotômetro em um comprimento de onde de $650 \mathrm{~nm}$. Desta forma foram obtidos os dados experimentais de concentração de dextrana azul, por meio de curva padrão de calibração no espectrofotômetro, permitindo a confecção da curva $C$ (Concentração x Tempo). O TDH médio real foi determinado de acordo à Equação 4.2 (Levenspiel 2000).

$$
\theta_{h}=\frac{\int_{0}^{\infty} t \cdot C(t) \cdot d t}{\int_{0}^{\infty} C(t) \cdot d t}
$$

Na qual $\theta_{h}$ é o TDH médio real, $C$ a concentração do traçador e $t$ o tempo.

A variância $\left(\delta^{2}\right)$ das curvas, que indica a dispersão da distribuição, foi calculada com a Equação 4.3 (Levenspiel 2000):

$$
\delta^{2}=\frac{\int_{0}^{\infty}\left(t-\theta_{h}\right)^{2} \cdot C(t) \cdot d t}{\int_{0}^{\infty} C(t) \cdot d t}
$$

A partir do cálculo da variância adimensional $\left(\delta_{\theta}{ }^{2}\right.$ ) (Equação 4.4), utilizou-se o modelo de tanques de mistura completa em série e calculou-se o número de reatores $(N)$ com a Equação 4.5 (Levenspiel 2000):

$$
\begin{gathered}
\delta_{\theta}^{2}=\frac{\delta^{2}}{\theta_{h}^{2}} \\
N=\frac{1}{\delta_{\theta}^{2}}
\end{gathered}
$$


A escolha dos valores de recirculação foi feita objetivando alcançar uma faixa que fosse do pistnado (altos valores de $N$ ) à mistura perfeita (baixos valores de $N$ ).

\subsection{Medição da produção de hidrogênio, monitoramento e análises fisico-químicas dos demais parâmetros e exames microbiológicos}

As análises de monitoramento do reator e a frequência de amostragem são mostradas na Tabela 4.2. Amostras da fase líquida (afluente e efluente) foram coletadas para análises de Demanda Química de Oxigênio (DQO), Sólidos Suspensos Voláteis (SSV), pH e concentrações de sacarose, ácidos voláteis e álcoois.

Tabela 4.2 - Análises de monitoramento

\begin{tabular}{|c|c|c|c|}
\hline Análise & Método & Amostragem & $\begin{array}{c}\text { Freqüîncia } \\
\text { (vezes/semana) }\end{array}$ \\
\hline $\begin{array}{l}\text { Produção de } \\
\text { hidrogênio }\end{array}$ & Vazão volumétrica & Saída de gases & 3 \\
\hline $\begin{array}{l}\text { Composição do } \\
\text { biogás }\end{array}$ & $\begin{array}{c}\text { Cromatografia } \\
\text { gasosa }\end{array}$ & Saída de gases & 3 \\
\hline Sacarose & Dubois et al., 1956 & Afluente e Efluente & 4 \\
\hline Ácidos Voláteis & $\begin{array}{c}\text { Cromatografia } \\
\text { gasosa }\end{array}$ & Efluente & 2 \\
\hline Álcoois & $\begin{array}{c}\text { Cromatografia } \\
\text { gasosa }\end{array}$ & Efluente & 2 \\
\hline $\mathrm{pH}$ & $\begin{array}{l}\text { Standard Methods } \\
\text { (APHA, 1998) }\end{array}$ & Afluente e Efluente & 4 \\
\hline $\begin{array}{l}\text { Demanda Química } \\
\text { de Oxigênio (DQO) }\end{array}$ & $\begin{array}{l}\text { Standard Methods } \\
\text { (APHA, 1998) }\end{array}$ & Afluente e Efluente & 2 \\
\hline $\begin{array}{l}\text { Sólidos Suspensos } \\
\text { Voláteis (SSV) }\end{array}$ & $\begin{array}{l}\text { Standard Methods } \\
\text { (APHA, 1998) }\end{array}$ & Efluente & 2 \\
\hline
\end{tabular}


Amostras da fase gasosa foram obtidas para análise da composição (hidrogênio, dióxido de carbono e metano) e a vazão de gás produzido foi medida pelo medidor de vazão MilligasCounter da Ritter $^{\circledR}$.

A análise da composição do biogás gerado por cada reator $\left(\mathrm{H}_{2}, \mathrm{CO}_{2}\right.$ e $\left.\mathrm{CH}_{4}\right)$ foi realizada no cromatógrafo a gás Shimadzu GC 2021® nas seguintes condições:

Coluna capilar: Carboxen 1010, comprimento de $30 \mathrm{~m}$, diâmetro interno de 0,53 mm e espessura da coluna de $0,30 \mu \mathrm{m}$.

Gás de arraste: Argônio.

Temperatura inicial do injetor: $200^{\circ} \mathrm{C}$.

Temperatura inicial do detector: $230^{\circ} \mathrm{C}$.

Vazão do gás de make up (Ar): $12 \mathrm{~mL} \cdot \mathrm{min}^{-1}$.

Detector: condutividade térmica.

Volume de amostra: $100 \mu \mathrm{L}$.

As análises de ácidos (acético, propiônico, isobutírico, butírico, isovalérico, valérico e capróico), acetona e álcoois (metanol, etanol e n-butanol) foram feitas por cromatografia gasosa com detector de ionização de chama (FID, Flame Ionization Dectector), empregando o método de "headspace" estático desenvolvido no LPB - EESC - USP. Usou-se acido crotônico (padrão para os ácidos) e isobutanol (padrão para alcoóis e acetona) em meio ácido (ácido sulfúrico).

Utilizou-se o cromatógrafo Shimadzu GC2010 ${ }^{\circledR}$ (software GC Solution) com as seguintes características:

Coluna HP-INNOWAX: comprimento de $30 \mathrm{~m}$, diâmetro interno de 0,25 mm e espessura de filme $25 \mu \mathrm{m}$.

Temperatura do injetor: $250^{\circ} \mathrm{C}$.

Temperatura do detector: $280^{\circ} \mathrm{C}$. 
Razão do Split: 1,0 .

Fluxo do gás de arraste $\left(\mathrm{H}_{2}\right): 30 \mathrm{~mL} \cdot \mathrm{min}^{-1}$.

Fluxo do make-up ou gás auxiliar $\left(\mathrm{N}_{2}\right): 30 \mathrm{~mL} \cdot \mathrm{min}^{-1}$.

Fluxo do gás da chama (ar sintético): $300 \mathrm{~mL} \cdot \mathrm{min}^{-1}$.

Volume da amostra injetada: $400 \mu \mathrm{L}$.

Seringa de $2.5 \mathrm{~mL}$.

Temperatura da seringa: $90^{\circ} \mathrm{C}$.

Temperatura de incubação da amostra: $100^{\circ} \mathrm{C}$.

O preparo das amostras foi feito em frascos - padrão de vidro com capacidade de 10 $\mathrm{mL}$, com tampa rosqueável e septo de silicone com $18 \mathrm{~mm}$ de diâmetro. Foram adicionados 1 g de $\mathrm{NaCl}, 2 \mathrm{~mL}$ de amostra, $70 \mu \mathrm{L}$ de solução de isobutanol, $100 \mu \mathrm{L}$ de solução de ácido crotônico (700 mg.L ${ }^{-1}$ ) e $200 \mu \mathrm{L}$ de solução de $\mathrm{H}_{2} \mathrm{SO}_{4} 2$ mol.L ${ }^{-1}$.

A determinação dos limites de detecção foi realizada por meio de cálculos estatísticos, com os resultados das curvas de calibração.

\subsection{Análises microscópicas}

A análise microbiológica da biomassa anaeróbia foi realizada por microscopia ótica, utilizando um microscópio Olympus modelo BX60-FLA. As amostras foram retiradas no final de cada operação.

\subsection{Cálculos}

De acordo com os resultados obtidos nas análises previamente descritas, utilizou-se o Microsoft Excel ${ }^{\circledR}$ para os cálculos da Equação 4.6 até a Equação 4.15, valores máximos, 
valores médios e desvio padrão. Cada equação está apresentada com as respectivas unidades de medida.

Vazão de líquido no reator $(Q)$ :

$$
Q\left(m L \cdot \min ^{-1}\right)=\frac{V}{\theta}
$$

Na qual, $V$ o volume útil do reator e $\theta$ o tempo de detenção hidráulica teórico aplicado, como explicado no item 4.5.

Velocidade global de conversão de sacarose $\left(v_{S}\right)$ :

$$
v_{S}\left(m m o l . h^{-1}\right)=\frac{Q \cdot\left(C_{S 0}-C_{S F}\right)}{M M_{S}}
$$

Na qual, $C_{S o}$ é a concentração de sacarose no meio afluente, $C_{S F}$ a concentração de sacarose no efluente e $M M_{S}$ é a massa molar da sacarose.

Vazão de biogás produzido no reator $\left(Q_{g}\right)$ :

$$
Q_{g}\left(m L \cdot h^{-1}\right)=\frac{V_{m} \cdot F_{m}}{t}
$$

Na qual, $V_{m}$ é o volume de gás obtido no medidor, $F_{m}$ é o fator de calibração do medidor obtido através de bolhômetro padrão e $t$ é o tempo da medida.

Distribuição em porcentagem de hidrogênio $\left(\%_{\mathrm{H} 2}\right)$, dióxido de carbono $\left(\%_{\mathrm{CO} 2}\right)$ e metano $\left(\%_{\mathrm{CH}}\right)$ no biogás:

$$
\begin{aligned}
& \%_{H 2}=\frac{\eta_{H 2}}{\eta} \\
& \%_{C O 2}=\frac{\eta_{C O 2}}{\eta} \\
& \%_{C H 4}=\frac{\eta_{C H 4}}{\eta}
\end{aligned}
$$

Na qual $\eta_{H 2}, \eta_{C O 2}, \eta_{C H 4}$ são os números de mol de cada gás contidos no biogás: hidrogênio, dióxido de carbono e metano, respectivamente. Esse conteúdo foi medido por 
cromatografia e calculado pelas curvas de calibração do cromatógrafo. O valor de $\eta$ corresponde ao número de mols totais na amostra de gás injetado, calculado usando a equação dos gases ideais (Equação 4.12).

$$
\eta=\frac{P \cdot V_{i}}{R \cdot T}
$$

Na qual, $P$ é a pressão de gás, $V_{i}$ volume de gás injetado, $R$ a constante universal dos gases ideais e $T$ a temperatura absoluta. No presente trabalho a pressão foi de 1 atm e a temperatura de $25^{\circ} \mathrm{C}$ (temperatura absoluta $=298 \mathrm{~K}$ ).

Vazão molar de hidrogênio $\left(v_{H 2}\right)$ :

$$
v_{H 2}\left(m m o l \cdot h^{-1}\right)=\frac{Q_{g} \cdot \eta_{H 2}}{V_{i}}
$$

Rendimento de hidrogênio $\left(Y_{H 2}\right)$ :

$$
Y_{H_{2}}\left(m_{2} H_{2} \cdot m_{s a c}^{-1}\right)=\frac{v_{H 2}}{v_{S}}
$$

Produção volumétrica de hidrogênio $(H P R)$ :

$$
\operatorname{HPR}\left(m L_{H 2} \cdot h^{-1} \cdot L^{-1}\right)=\frac{Q_{g} \cdot \%_{H 2}}{V_{\theta R}}
$$

Na qual $V_{\theta R}$ é o volume calculado com base nos tempos de detenção hidráulica reais obtidos nos ensaios hidrodinâmicos da primeira fase juntamente com a vazão de $21 \mathrm{~mL} / \mathrm{min}$ (explicada no item 4.5). 


\section{RESULTADOS E DISCUSSÕES}

\subsection{Escolha da faixa de razão de recirculação aplicada por meio de ensaios hidrodinâmicos}

A primeira fase do experimento consistiu na escolha das vazões de recirculação que seriam utilizadas durante o experimento. Buscou-se escolher valores que abrangessem os extremos de comportamento hidrodinâmico, ou seja, que fossem do comportamento pistonado ao comportamento de mistura completa. Para isso foram feitos ensaios hidrodinâmicos do tipo pulso utilizando dextrana azul como traçador, com o reator apenas com o material suporte sem biomassa. As curvas obtidas para cada razão de recirculação são apresentadas na Figura 5.1 


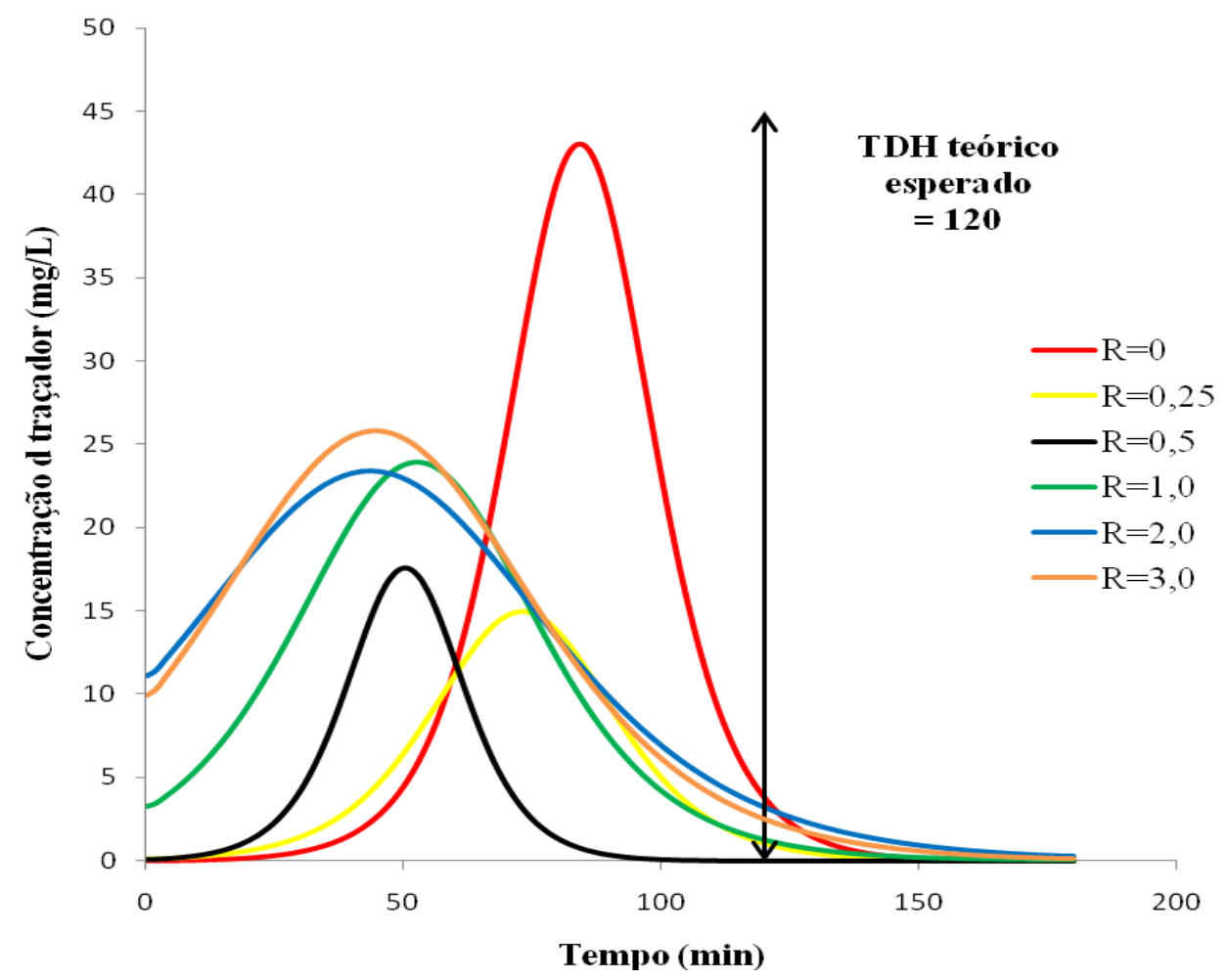

Figura 5.1 - Curvas de concentração do traçador em função do tempo

A Tabela 5.1 apresenta um resumo com os principais dados obtidos com os ensaios.

\begin{tabular}{lcc}
\multicolumn{2}{c}{ Tabela 5.1 - Dados obtidos nos ensaios hidrodinâmicos } \\
\hline $\mathbf{R}$ & $\boldsymbol{\theta}_{\mathbf{h}}(\mathbf{m i n})$ & $\mathbf{N}$ \\
\hline 0 & 85,56 & 31 \\
0,25 & 74,96 & 16 \\
0,5 & 55,47 & 10 \\
1,0 & 58,99 & 5 \\
2,0 & 56,42 & 4 \\
3,0 & 54,04 & 4
\end{tabular}


Os valores obtidos para $\mathrm{R}=0$ estão de acordo com os valores obtidos por Rojas (2010), abaixo, porém, do valor teórico de 2 horas esperado, indicando possíveis formações de caminhos preferenciais ou zonas mortas. Os dados obtidos quando a recirculação foi

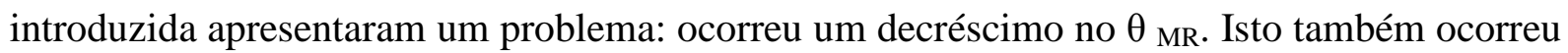
possivelmente devido à formação de caminhos preferências ou zonas mortas na câmara de alimentação e recirculação com o aumento da vazão de recirculação (e, por conseguinte, da velocidade ascensional do afluente no reator), como sugere Levenspiel (2000). Provavelmente seja necessário buscar uma nova forma de entrada tanto da alimentação quanto da recirculação para tentar resolver esse problema em futuros trabalhos.

A escolha dos valores de recirculação foi feita levando-se em consideração que os experimentos deveriam ser feitos com graus de mistura diferenciados para análise da influência dessa variável sobre a produção de hidrogênio. Analisando-se a Tabela 5.1 é possível observar que à partir de $\mathrm{R}=1,0 \mathrm{o} \mathrm{N}$ permanece praticamente constante. Com isso os valores escolhidos foram $\mathrm{R}=0,25$ (mais próximo do pistonado), $\mathrm{R}=0,5, \mathrm{R}=1,0$ e $\mathrm{R}=2,0$ (mais próximo da mistura perfeita). $\mathrm{R}=0$ não foi escolhido pois ele apresentaria condições diferenciadas dos outros reatores (ele não possuiria reintrodução de efluente com todos os metabólitos presentes). O ideal seria aplicar uma taxa de recirculação mínima, bem próxima de zero, o que na prática ficaria inviável.

\subsection{Produção de hidrogênio}

A Figura 5.2 apresenta a variação temporal da produção de biogás $\left(Q_{G}\right)$ para $\mathrm{R}=0,25$, $\mathrm{R}=0,5, \mathrm{R}=1,0$ e $\mathrm{R}=2,0$. Além disso, a Tabela 5.2 apresenta os valores máximos e médios de produção de biogás para as mesmas condições. 


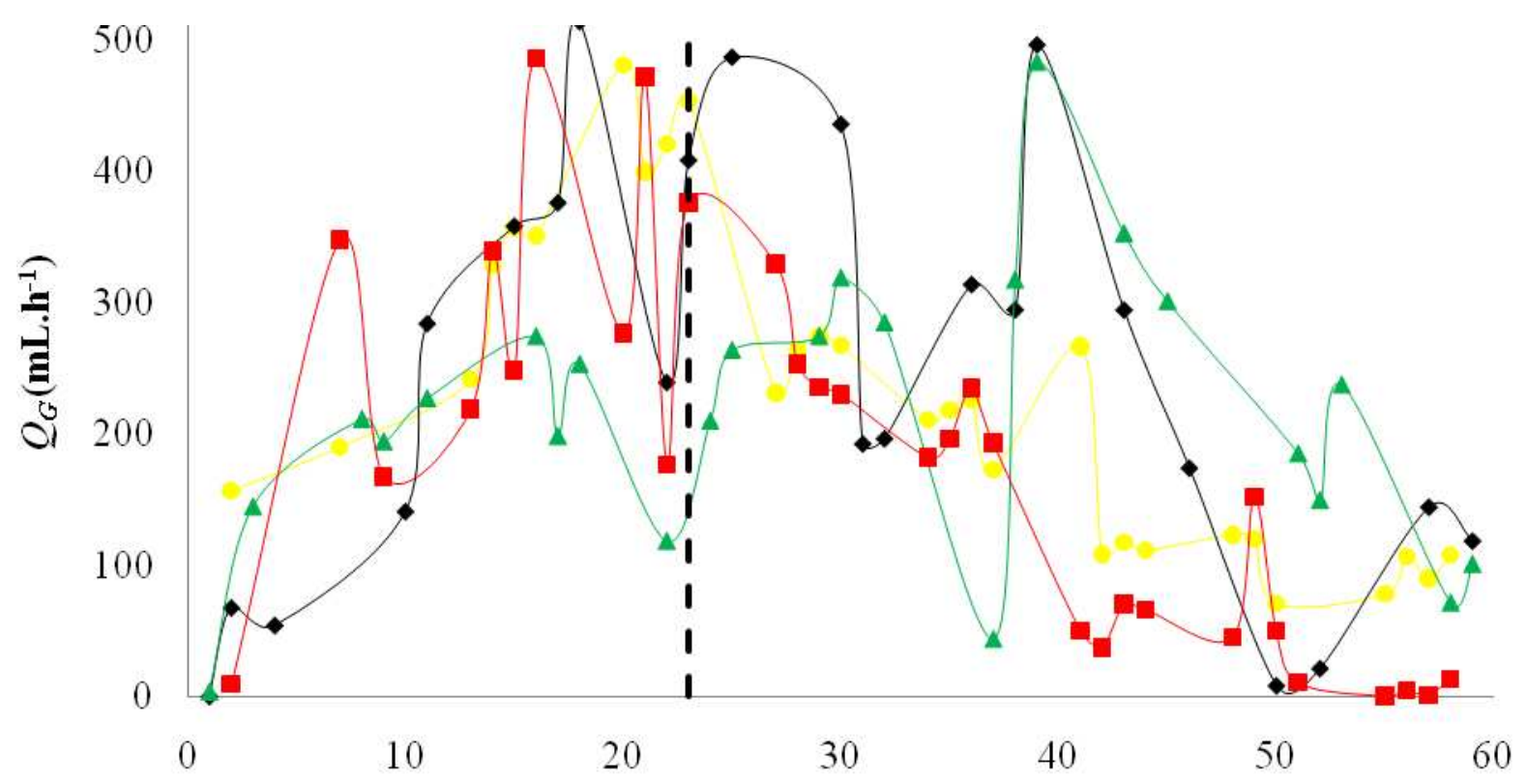

Tempo de operação (dias)

Figura 5.2 - Produção de biogás $\left(Q_{G}\right)$ para $R=0,25(\odot), R=0,5(\diamond), R=1,0(\Delta)$ e $R=2,0$ ( $($ )

Tabela 5.2 Valores médios e máximos da vazão de biogás produzido. $Q_{G}($ mmol H2.h-1)

\begin{tabular}{|c|c|c|c|c|c|c|}
\hline \multirow[t]{2}{*}{$\mathbf{R}$} & \multicolumn{2}{|c|}{ Tempo total } & \multicolumn{2}{|c|}{$\begin{array}{l}\text { Transiente } \\
\text { (até o dia 22) }\end{array}$} & \multicolumn{2}{|c|}{$\begin{array}{c}\text { Estabilização (à partir } \\
\text { do dia 23) }\end{array}$} \\
\hline & Média & Máx & Média & Máx & Média & Máx \\
\hline 0,25 & $225,45 \pm 119,08$ & 480,53 & $337,65 \pm 109,95$ & 480,53 & $166,39 \pm 73,06$ & 273,75 \\
\hline 0,5 & $244,10 \pm 162,21$ & 513,64 & $244,03 \pm 172,91$ & 513,65 & $244,15 \pm 160,68$ & 496,00 \\
\hline 1,0 & $217,05 \pm 106,94$ & 482,34 & $180,18 \pm 82,18$ & 273,77 & $239,18 \pm 116,31$ & 482,34 \\
\hline 2,0 & $176,40 \pm 141,45$ & 485,43 & $283,19 \pm 140,47$ & 82,18 & $117,66 \pm 104,76$ & 329,05 \\
\hline
\end{tabular}

É possível observar na Tabela 5.2 que a produção de biogás apresentou diferença para as condições de recirculação analisadas. Foi observado aumento da produção média e máxima 
de biogás até $\mathrm{R}=0,5$ e depois uma queda, mostrando que há uma possível condição ótima, conforme previsto.

Um fato comum observado na Figura 5.2 é a instabilidade na produção de biogás. Essa instabilidade foi observada em outros trabalhos realizados com esse tipo de reator aplicado à produção de hidrogênio (Fernandes, 2008; Rojas, 2010) e será discutida ao final desse capítulo, no item 5.5. Com isso se torna complicado encontrar uma divisão entre a fase transiente e a fase estacionária do processo.Além disso, é possível observar na Figura 5.2 que a condição $\mathrm{R}=2,0$ apresentou uma queda mais acentuada no final da operação, se aproximando muito de zero.

O estabelecimento do estado estacionário só foi possível a partir da avaliação temporal da conversão de sacarose, apresentada na Figura 5.3.

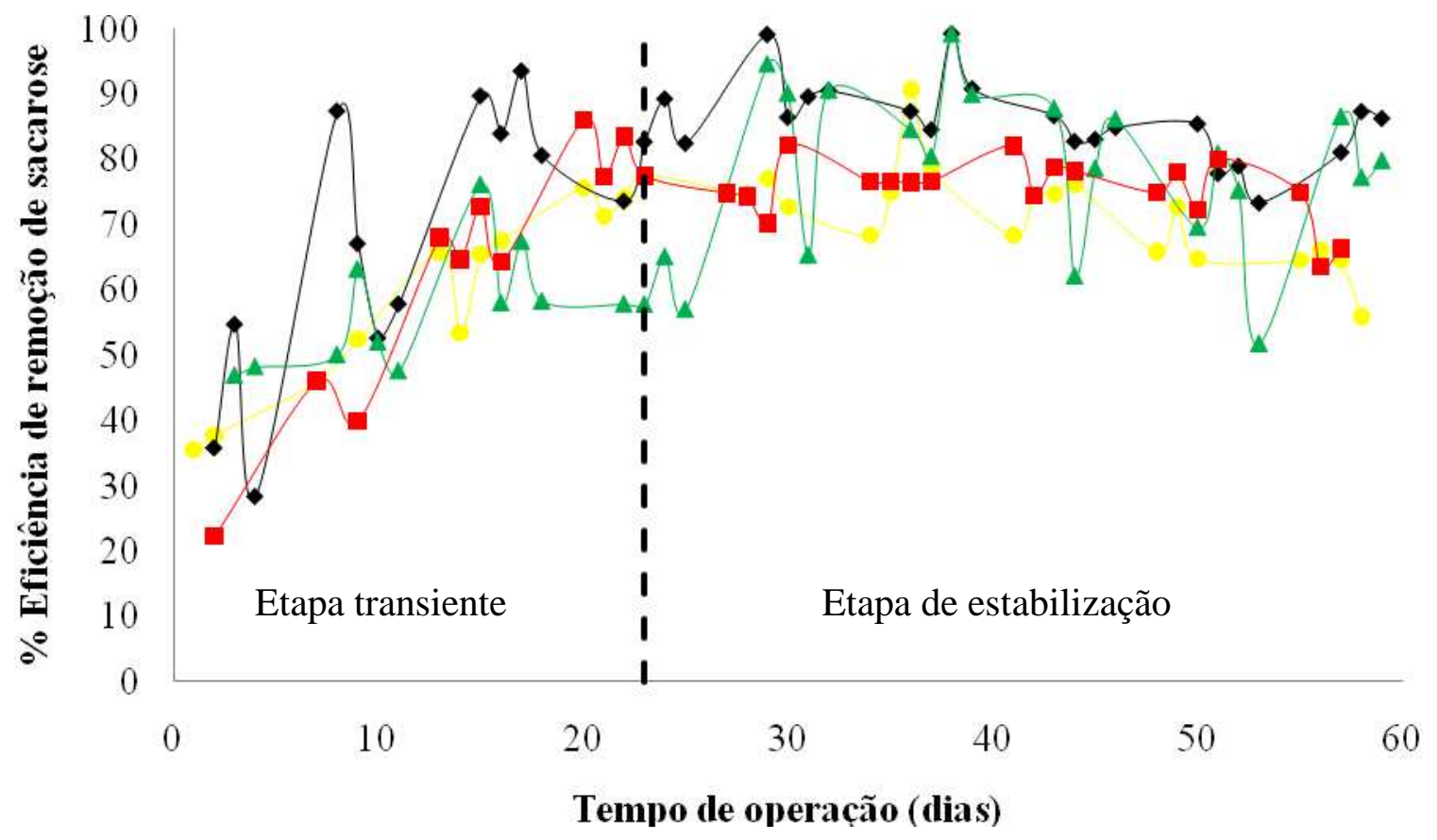

Figura 5.3 - Eficiência de remoção de sacarose para $R=0,25(\odot), R=0,5(\diamond), R=1,0(\Delta)$ e $R=2,0$

$(\square)$ 
A estabilização da degradação da sacarose aconteceu à partir do $23^{\circ}$ dia. Esse valor se apresentou bem próximo do valor encontrado por Rojas (2010). As remoções médias de sacarose, porém, apresentaram valores menores do que os encontrados no mesmo trabalho e no trabalho de Fernandes (2008), próximos a 90\% para todas as condições. As eficiências médias encontradas podem ser observadas na Tabela 5.3.

\begin{tabular}{cc} 
Tabela 5.3 - Valores médios de eficiência de remoção de sacarose. & \multicolumn{1}{c}{ Média } \\
\hline 0,25 & $67,21 \pm 12,03$ \\
0,5 & $79,22 \pm 16,09$ \\
1,0 & $70,79 \pm 15,52$ \\
2,0 & $70,31 \pm 14,03$
\end{tabular}

Esta queda na eficiência de remoção da sacarose já era algo esperado. De acordo com Von Sperling (1996), em um sistema onde a recirculação é feita diretamente do efluente do reator (com baixa concentração de substrato) a recirculação pode provocar uma diluição da concentração afluente do substrato. Dessa forma, a eficiência do sistema se reduz. No caso de Rojas (2010) e Fernandes (2008), o reator foi operado sem recirculação da fase líquida, apresentando comportamento hidrodinâmico mais próximo do pistonado, podendo, nesse caso, ser representado por 31 reatores de mistura perfeita de igual volume em série, de acordo com os ensaios hidrodinâmicos realizados e apresentados no item 5.1.

Utilizando cromatografia gasosa determinou-se a composição do biogás produzido. Mesmo com a queda na produção do biogás como foi mostrado na Figura 5.2, nota-se que a composição do biogás manteve-se constante em cada fase de operação (Figura 5.4). Os gases encontrados no biogás foram o hidrogênio e o gás carbônico. Em nenhum momento foi observada a presença de metano. 


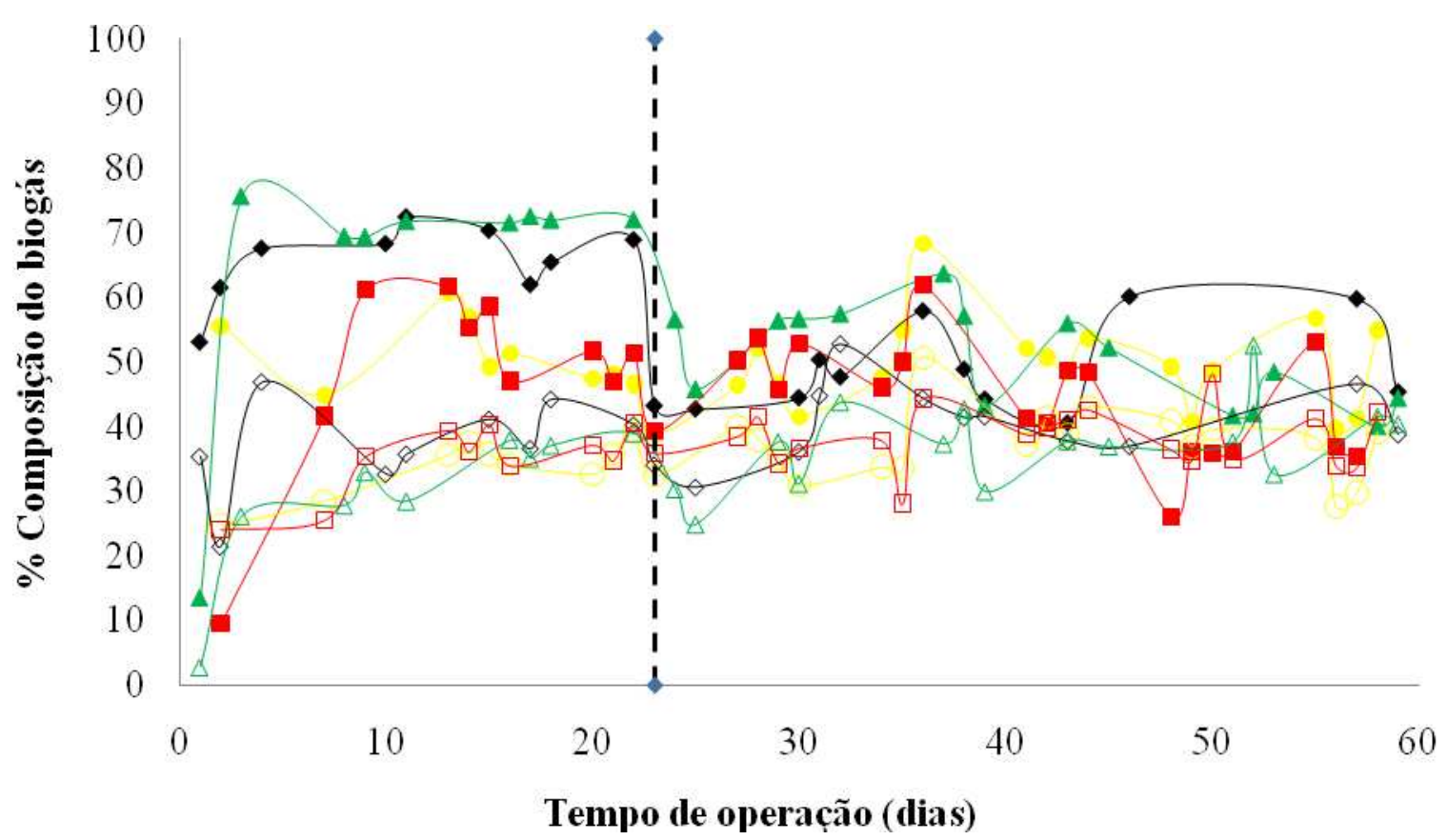

Figura 5.4 - Distribuição em porcentagem de $\mathrm{H}_{2}\left(\% H_{2}\right)$ para $R=0,25(\circ), \mathbf{R = 0 , 5}(\bullet), \mathbf{R = 1 , 0}(\Delta)$ e $\mathrm{R}=2,0(\square)$ e de $\mathrm{CO}_{2}\left(\% \mathrm{CO}_{2}\right)$ para $\mathrm{R}=0,25(\odot), \mathrm{R}=0,5(\diamond), \mathrm{R}=1,0(\triangle)$ e $\mathrm{R}=2,0(\square)$

As porcentagens médias e máximas tanto de hidrogênio quanto de gás carbônico para cada fase de operação estão apresentadas na Tabela 5.4. Os valores obtidos encontram-se próximos àqueles observados por Rojas (2010) e O-Thong et al. (2008), sendo que este trabalhou com um reator UASB (upflow anaerobic sludge blanket) alimentado com sacarose. Foram realizados testes estatísticos (ANOVA e Teste Tukey) através do programa Statistica $9.1^{\circledR}$ da StatSoft Inc., tanto para a porcentagem de hidrogênio quanto para a de gás carbônico, com o intuito de determinar se as condições eram estatisticamente diferentes. De forma simplificada, o ANOVA compara todo o grupo, indicando se nele existe uma diferenças

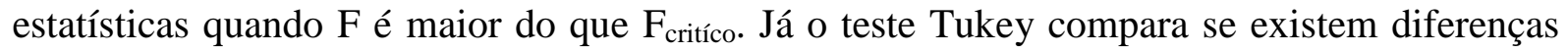
estatísticas entre cada condição do grupo. Caso esta comparação seja menor do que $5 \%(0,05)$, então existe diferença estatística entre os dois grupos comparados. Os resultados encontramse na Tabela 5.5 (teste ANOVA $\% H_{2}$ ), Tabela 5.6 (teste Tukey $\% H_{2}$ ) e Tabela 5.7 (teste ANOVA $\% \mathrm{CO}_{2}$ ). Como pode se observar, as porcentagens de gás carbônico se mostraram 
estatisticamente similares. Porém, ocorreu o contrário com as porcentagens de hidrogênio, sendo que a condição $\mathrm{R}=0,5$ apresentou o maior percentual.

Tabela 5.4 - Valores médios e máximos da \% de hidrogênio e gás carbônico no biogás.

\begin{tabular}{lcccc}
\hline \multirow{2}{*}{ Recirculação } & \multicolumn{3}{c}{$\% \mathrm{H}_{2}$} & \multicolumn{2}{c}{$\% \mathrm{CO}_{2}$} \\
\cline { 2 - 5 } & Média & Máximo & Média & Máximo \\
\hline $\mathrm{R}=0,25$ & $49,75 \pm 6,66$ & 68,36 & $36,09 \pm 5,26$ & 50,61 \\
$\mathrm{R}=0,5$ & $55,91 \pm 10,62$ & 72,47 & $39,02 \pm 6,70$ & 52,70 \\
$\mathrm{R}=1,0$ & $56,19 \pm 14,77$ & 75,60 & $34,35 \pm 9,22$ & 52,54 \\
$\mathrm{R}=2,0$ & $45,71 \pm 11,13$ & 61,90 & $37,04 \pm 5,15$ & 48,08 \\
\hline
\end{tabular}

Tabela 5.5 - Resumo do teste ANOVA: Fator único para $\% \mathrm{H}_{2}$.

\begin{tabular}{|c|c|c|c|c|c|c|}
\hline & Grupo & Contagem & Soma & Média & Variância & \\
\hline & $\mathrm{R}=0,25$ & 28 & 1392.97 & 49.74894 & 44.30876 & \\
\hline & $\mathrm{R}=0,5$ & 21 & 1174.158 & 55.91228 & 112.8671 & \\
\hline & $\mathrm{R}=1,0$ & 24 & 1348.455 & 56.18562 & 218.1691 & \\
\hline & $\mathrm{R}=2,0$ & 30 & 1371.45 & 45.71499 & 123.9622 & \\
\hline $\begin{array}{l}\text { Fonte da } \\
\text { variação }\end{array}$ & $S Q$ & $g l$ & $M Q$ & $F$ & valor-P & F crítico \\
\hline \multicolumn{7}{|l|}{ Entre } \\
\hline grupos & 2022.636 & 3 & 674.2119 & 5.531606 & 0.001492 & 2.696469 \\
\hline
\end{tabular}

Dentro dos

$\begin{array}{llll}\text { grupos } & 12066.47 & 99 & 121.8836\end{array}$

Total $\quad 14089.11 \quad 102$


Tabela 5.6 - Resumo do Teste Tukey para \% $\mathrm{H}_{2}$.

\begin{tabular}{ccccc}
\hline & $\mathrm{R}=0,25$ & $\mathrm{R}=0,5$ & $\mathrm{R}=1,0$ & $\mathrm{R}=2,0$ \\
$\mathrm{R}=0,25$ & - & 0.220747 & 0.161666 & 0.508308 \\
$\mathrm{R}=0,5$ & 0.220747 & - & 0.999822 & 0.008628 \\
$\mathrm{R}=1,0$ & 0.161666 & 0.999822 & - & 0.004423 \\
$\mathrm{R}=2,0$ & 0.508308 & 0.008628 & 0.004423 & - \\
\hline
\end{tabular}

Tabela 5.7 - Resumo do teste ANOVA: Fator único para \% $\mathrm{CO}_{2 .}$

Grupo Contagem Soma Média Variância

$\begin{array}{lllll}\mathrm{R}=0,25 & 28 & 1010.48 & 36.08 & 27.71\end{array}$

$\begin{array}{lllll}\mathrm{R}=0,5 & 21 & 819.3797 & 39.01 & 44.94 \\ \mathrm{R}=1,0 & 24 & 824.3557 & 34.34 & 84.95 \\ \mathrm{R}=2,0 & 30 & 1111.251 & 37.04 & 26.47\end{array}$

\begin{tabular}{|c|c|c|c|c|c|c|}
\hline $\begin{array}{l}\text { Fonte da } \\
\text { variação }\end{array}$ & $S Q$ & $g l$ & $M Q$ & $F$ & valor-P & F crítico \\
\hline Entre grupos & 257.48 & 3.00 & 85.83 & 1.94 & 0.13 & 2.70 \\
\hline Dentro dos & & & & & & \\
\hline grupos & 4368.88 & 99.00 & 44.13 & - & - & - \\
\hline Total & 4626.36 & 102.00 & - & - & - & - \\
\hline
\end{tabular}

Com os valores da produção volumétrica do biogás e as porcentagens de hidrogênio no mesmo biogás determinou-se a vazão molar de hidrogênio $\left(v_{H_{2}}\right)$ (Figura 5.5). O valor máximo obtido foi de $13,76 \mathrm{mmol} \mathrm{H}_{2} \cdot \mathrm{h}^{-1}$ durante a condição de operação $\mathrm{R}=0,5$. Da mesma forma que para a vazão de biogás, o $\mathrm{R}=2,0$ apresentou uma queda mais acentuada no final da operação, se aproximando muito de zero. Os valores médios e máximos da produção volumétrica de hidrogênio para cada operação encontram-se na Tabela 5.8. Observa-se que os melhores 
valores, tanto médios quanto máximos, em todas as fases de operação, foram obtidos na etapa transiente. O teste ANOVA e o teste Tukey mostraram que as fases de operação são realmente diferentes estatisticamente, com a melhor condição obtida entre $\mathrm{R}=0,5$ e 1,0 (Tabelas 5.9 e $5.10)$.

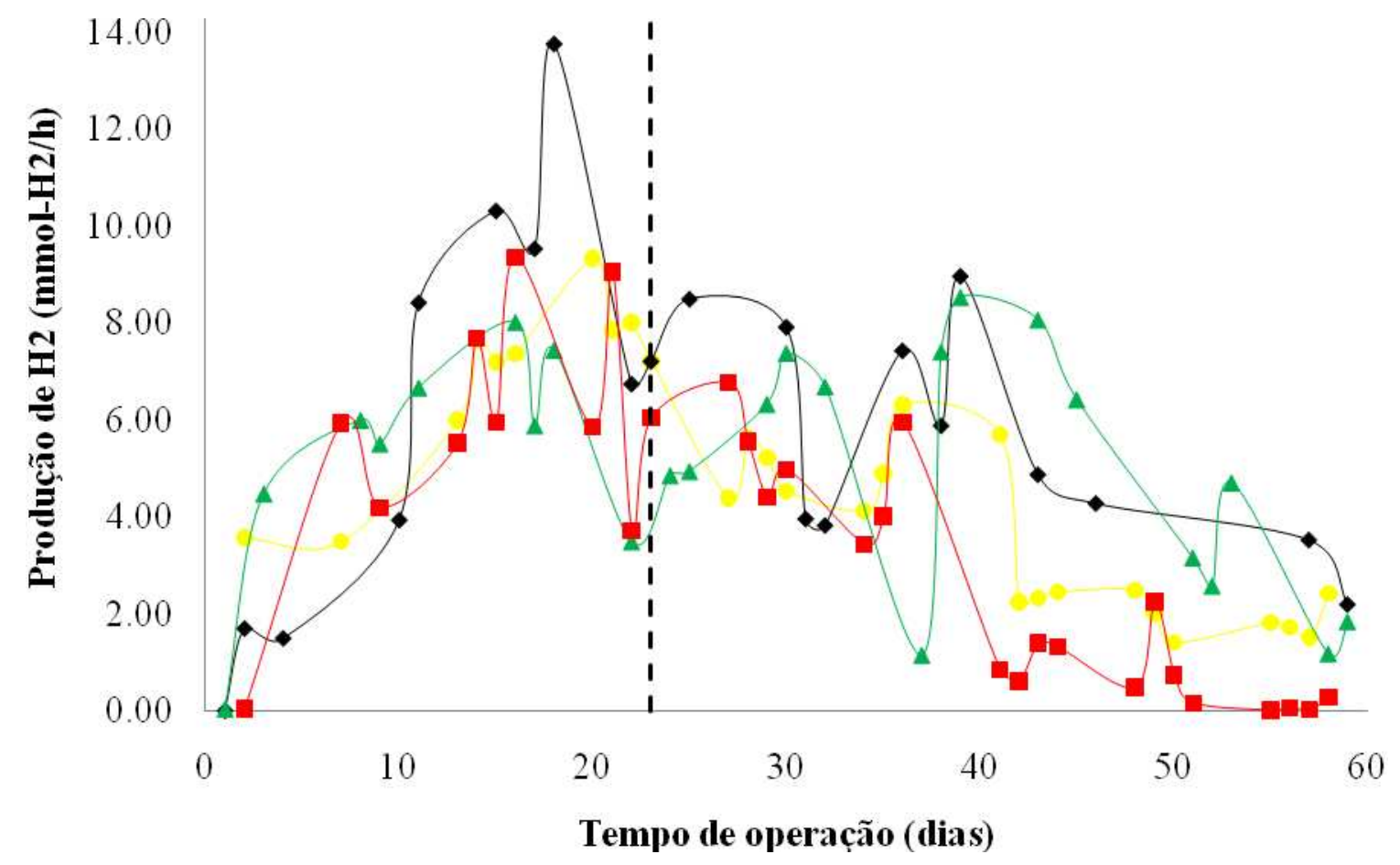

Figura 5.5 - Vazão molar de hidrogênio $\left(v_{H 2}\right)$ para $R=0,25(\odot), \mathbf{R = 0 , 5}(\bullet), \mathbf{R = 1 , 0}(\Delta)$ e $\mathbf{R = 2 , 0}(\square)$ 
Tabela 5.8 - Vazão molar de hidrogênio $\left(v_{H_{2}}\right)$ para diferentes taxas de recirculação. $v_{H 2}\left(\mathbf{m m o l ~ H}_{2} \cdot \mathrm{h}^{-1}\right)$

\begin{tabular}{lcccccc}
\hline & \multicolumn{2}{c}{ Tempo total } & \multicolumn{2}{c}{ Transiente } & \multicolumn{2}{c}{ Estabilização (à } \\
$\mathbf{R}$ & & & \multicolumn{2}{c}{ (até o dia 22) } & \multicolumn{2}{c}{ partir do dia 23) } \\
\cline { 2 - 7 } & Média & Máximo & Média & Máximo & Média & Máximo \\
\hline 0,25 & $4,60 \pm 2,37$ & 9,33 & $6,76 \pm 1,90$ & 9,33 & $3,40 \pm 1,66$ & 6,31 \\
0,5 & $5,92 \pm 3,41$ & 13,76 & $6,31 \pm 4,44$ & 13,76 & $5,57 \pm 2,29$ & 8,96 \\
1,0 & $5,10 \pm 2,43$ & 8,53 & $5,27 \pm 2,41$ & 8,01 & $5,01 \pm 2,52$ & 8,53 \\
2,0 & $3,55 \pm 2,92$ & 9,35 & $5,75 \pm 2,59$ & 9,35 & $2,27 \pm 2,31$ & 6,76 \\
\hline
\end{tabular}

Tabela 5.9 - Resumo do teste ANOVA: Fator único para vazão molar de hidrogênio $\left(v_{\mathrm{H} 2}\right)$.

\begin{tabular}{ccccc}
\hline Grupo & Contagem & Soma & Média & Variância \\
\hline $\mathrm{R}=0,25$ & 28 & 128.76 & 4.60 & 5.63 \\
$\mathrm{R}=0,5$ & 21 & 124.39 & 5.92 & 11.62 \\
$\mathrm{R}=1,0$ & 24 & 122.51 & 5.10 & 5.91 \\
$\mathrm{R}=2,0$ & 30 & 106.47 & 3.55 & 8.53
\end{tabular}

\begin{tabular}{ccccccc}
$\begin{array}{c}\text { Fonte da } \\
\text { variação }\end{array}$ & $S Q$ & $\boldsymbol{g l}$ & $\boldsymbol{M Q}$ & $\boldsymbol{F}$ & valor-P & $\boldsymbol{F}$ crítico \\
\hline Entre & & & & & & \\
grupos & 75.35 & 3 & 25.12 & 3.24 & 0.03 & 2.70
\end{tabular}

Dentro dos

$\begin{array}{llll}\text { grupos } & 767.81 & 99 & 7.76\end{array}$

Total $\quad 843.17 \quad 102$


Tabela 5.10 - Resumo do Teste Tukey para vazão molar de hidrogênio $\left(\mathbf{v}_{\mathbf{H} 2}\right)$.
\[ \mathrm{R}=0,25 \quad \mathrm{R}=0,5 \quad \mathrm{R}=1,0 \quad \mathrm{R}=2,0 \]

$\begin{array}{ccccc}\mathrm{R}=0,25 & - & 0.356864 & 0.914224 & 0.481389 \\ \mathrm{R}=0,5 & 0.356864 & - & 0.758960 & 0.017945 \\ \mathrm{R}=1,0 & 0.914224 & 0.758960 & - & 0.180699 \\ \mathrm{R}=2,0 & 0.481389 & 0.017945 & 0.180699 & -\end{array}$

O rendimento compara a produção de hidrogênio em relação à sacarose degradada. $\mathrm{O}$ comportamento deste rendimento $\left(Y_{H 2}\right)$ ao longo do tempo está apresentado na Figura 5.6.

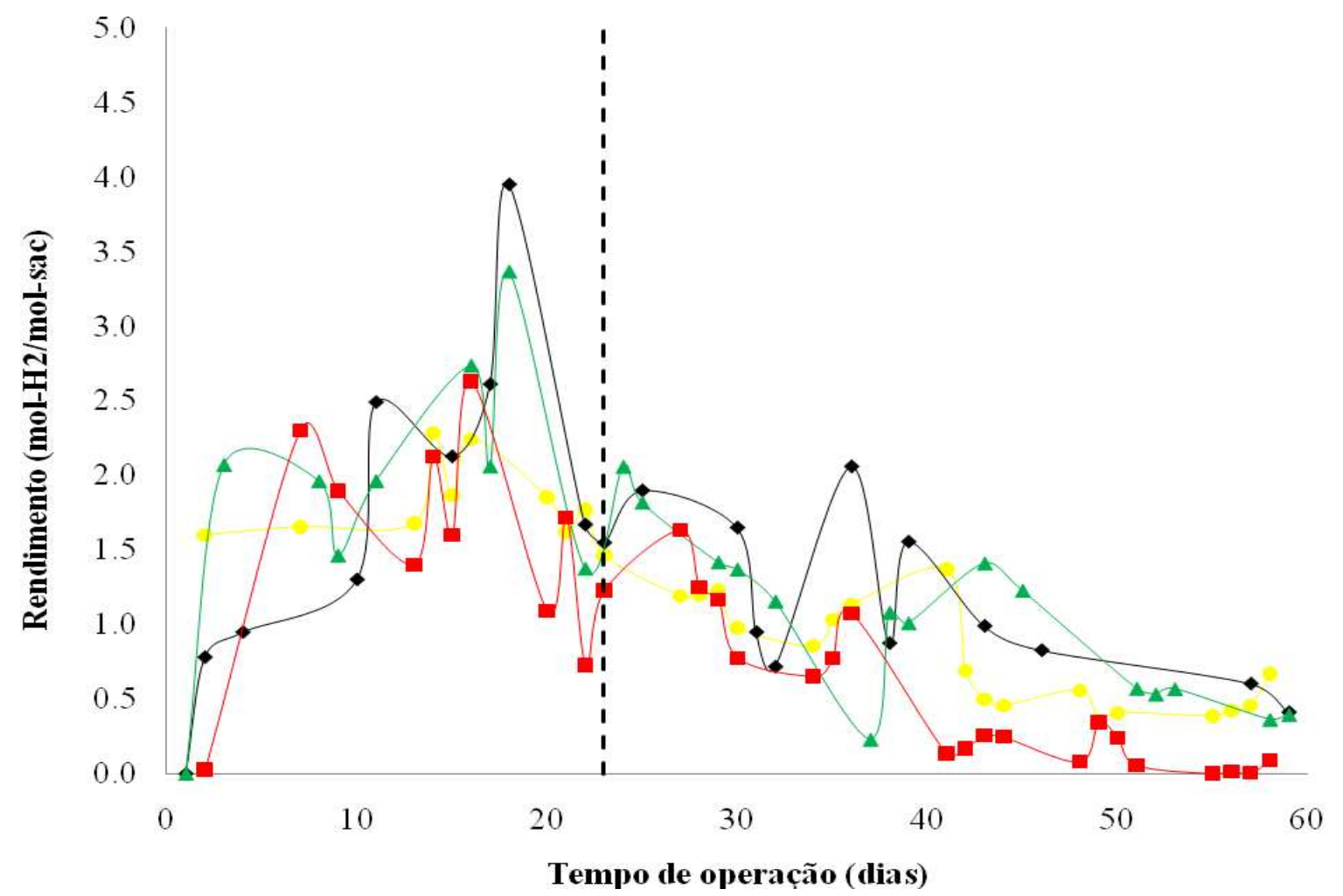

Figura 5.6 - Rendimento de hidrogênio ( $\left.Y_{H 2}\right)$ para R0,25 ( ) $)$ R0,5 (४), R1,0 ( $\triangle$ ) e R2,0 (匹)

O valor máximo de rendimento de hidrogênio foi obtido para $\mathrm{R}=0,5$ e foi de $3,95 \mathrm{ml}$ de $\mathrm{H}_{2}$.(mol sacarose $)^{-1}$. Este valor é $49,3 \%$ do valor teórico máximo estabelecido pela estequiometria da melhor reação para produção de hidrogênio que é quando toda sacarose é 
convertida em ácido acético (gerando 8 mols de $\mathrm{H}_{2}$ ). A razão $\mathrm{R}=0,5$ também apresentou os melhores valores médios de rendimento. Como ocorrido na produção volumétrica de $\mathrm{H}_{2}$, a fase transiente apresentou melhores resultados médios e máximos em todas as fases de operação (Tabela 5.11). As análises estatísticas ANOVA (Tabela 5.12) e teste Tukey (Tabela 5.13) comprovaram que existem diferenças entre as fases de operação.

Tabela 5.11 - Rendimento de hidrogênio $\left(Y_{H 2}\right)$ para diferentes taxas de recirculação.

\section{$Y_{H_{2}}\left(\mathrm{~mol} \mathrm{H}_{2} \cdot \mathrm{mol} \mathrm{sac}^{-1}\right)$}

\begin{tabular}{lcccccc}
\hline & \multicolumn{2}{c}{ Tempo total } & \multicolumn{2}{c}{ Transiente } & \multicolumn{2}{c}{ Estabilização (à } \\
$\mathbf{R}$ & & & (até o dia 22) & \multicolumn{2}{c}{ partir do dia 23) } \\
\cline { 2 - 7 } & Média & Máximo & Média & Máximo & Média & Máximo \\
\hline 0,25 & $1,14 \pm 0,60$ & 2,28 & $1,80 \pm 0,27$ & 2,28 & $0,77 \pm 0,35$ & 1,37 \\
0,5 & $1,43 \pm 0,90$ & 3,95 & $1,74 \pm 1,11$ & 3,95 & $1,14 \pm 0,55$ & 2,06 \\
1,0 & $1,34 \pm 0,82$ & 3,37 & $1,89 \pm 0,93$ & 3,37 & $1,01 \pm 0,55$ & 2,06 \\
2,0 & $0,86 \pm 0,78$ & 2,63 & $1,52 \pm 0,74$ & 2,63 & $0,47 \pm 0,50$ & 1,63 \\
\hline
\end{tabular}


Tabela 5.12 - Resumo do teste ANOVA: Fator único para o rendimento de hidrogênio $\left(Y_{H 2}\right)$

\begin{tabular}{|c|c|c|c|c|c|c|}
\hline \multirow[t]{5}{*}{ - } & Grupo & Contagem & Soma & Média & Variância & \\
\hline & $\mathrm{R}=0,25$ & 28 & 31.90 & 1.14 & 0.36 & \\
\hline & $\mathrm{R}=0,5$ & 21 & 29.95 & 1.43 & 0.81 & \\
\hline & $\mathrm{R}=1,0$ & 24 & 35.17 & 1.47 & 0.74 & \\
\hline & $\mathrm{R}=2,0$ & 30 & 25.70 & 0.86 & 0.61 & \\
\hline $\begin{array}{l}\text { Fonte da } \\
\text { variação }\end{array}$ & $S Q$ & $g l$ & $M Q$ & $F$ & valor-P & F crítico \\
\hline $\begin{array}{l}\text { Entre } \\
\text { grupos }\end{array}$ & 6.40 & 3 & 2.13 & 3.50 & 0.02 & 2.70 \\
\hline \multicolumn{7}{|l|}{ Dentro dos } \\
\hline grupos & 60.33 & 99 & 0.61 & - & - & - \\
\hline Total & 66.73 & 102 & - & - & - & - \\
\hline
\end{tabular}

Tabela 5.13 - Resumo do Teste Tukey para o rendimento de hidrogênio $\left(Y_{H 2}\right)$

$\begin{array}{lcccc} & \mathrm{R}=0,25 & \mathrm{R}=0,5 & \mathrm{R}=1,0 & \mathrm{R}=2,0 \\ \mathrm{R}=0,25 & & 0.440455 & 0.582460 & 0.515676 \\ \mathrm{R}=0,5 & 0.440455 & & 0.998364 & 0.027110 \\ \mathrm{R}=1,0 & 0.582460 & 0.998364 & & 0.056520 \\ \mathrm{R}=2,0 & 0.515676 & 0.027110 & 0.056520 & \end{array}$

Por ultimo obteve-se a produção volumétrica de hidrogênio (HPR) dividindo-se a vazão volumétrica de hidrogênio pelo volume útil do reator (que variou em cada fase de operação, como explicado anteriormente) (Figura 5.7). O valor máximo obtido foi de 289,77 $\mathrm{mL}$ de $\mathrm{H}_{2} \cdot \mathrm{h}^{-1} \cdot \mathrm{L}^{-1}$ para $\mathrm{R}=0,5$. 


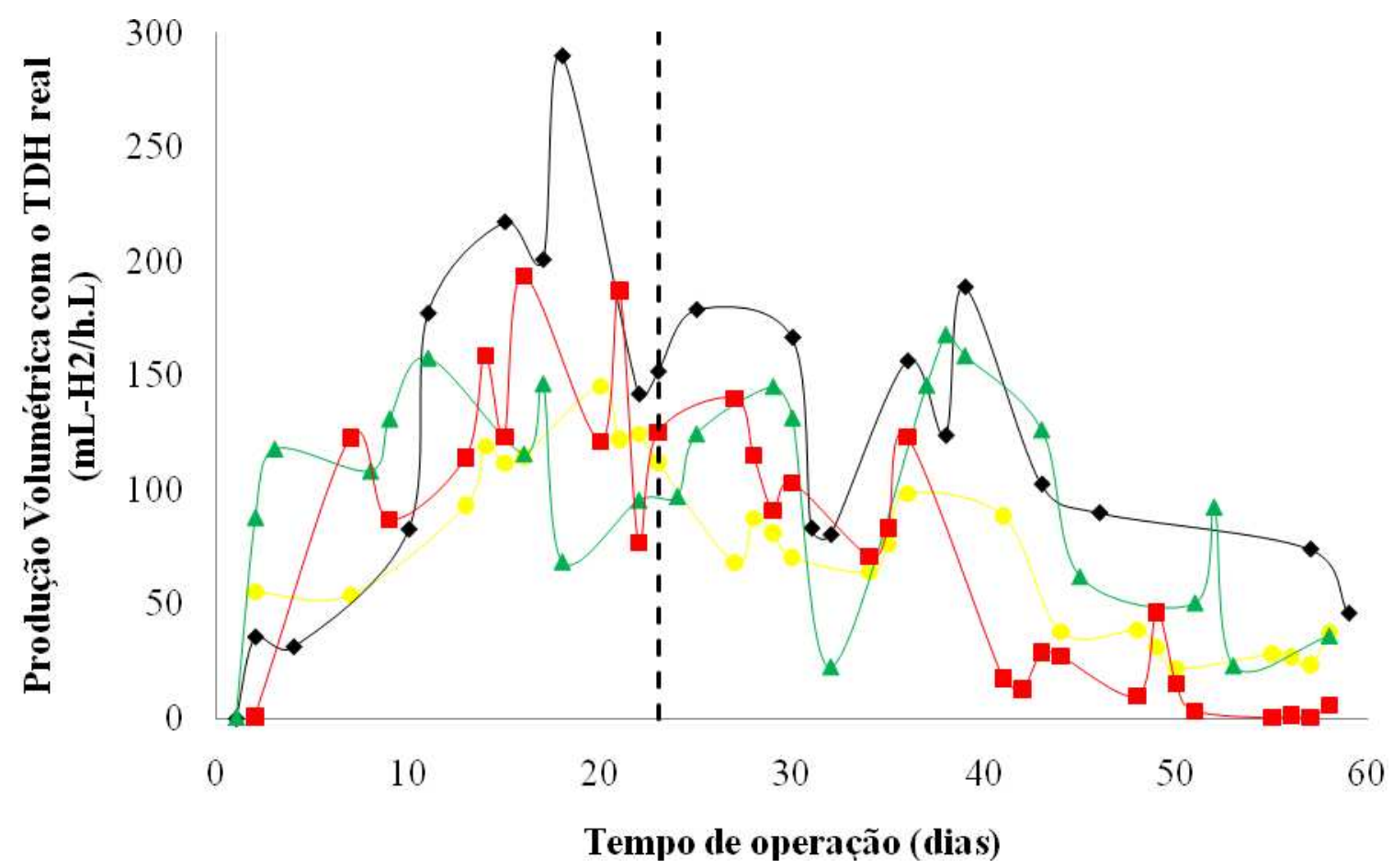

Figura 5.7 - Produção volumétrica de hidrogênio (HPR) para $R=0,25(\odot), \mathbf{R = 0 , 5}(\diamond), \mathbf{R = 1 , 0}(\triangle)$ e $\mathbf{R}=\mathbf{2 , 0}(\boldsymbol{\square})$

Como ocorrido nos demais parâmetros analisados anteriormente, a produção volumétrica de hidrogênio apresentou melhores resultados médios e máximos na fase transiente (Tabela 5.14). As análises estatísticas ANOVA (Tabela 5.15) e teste Tukey (Tabela 5.16) comprovaram que os resultados obtidos são estatisticamente diferentes e que a melhor condição para produção volumétrica de hidrogênio apresentou-se entre R=0,5 e 1,0. 
Tabela 5.14 - Produção volumétrica de hidrogênio (HPR) para diferentes taxas de recirculação. Produção volumétrica de hidrogênio (HPR) $\left(\mathrm{mL} \mathrm{H}_{2} \cdot \mathrm{h}^{-1} \cdot \mathbf{L}^{-1}\right)$

\begin{tabular}{|c|c|c|c|c|c|c|}
\hline \multirow[t]{2}{*}{$\mathbf{R}$} & \multicolumn{2}{|c|}{ Tempo total } & \multicolumn{2}{|c|}{ Transiente } & $\begin{array}{r}\text { Estabilização } \\
\text { do dia }\end{array}$ & à partir \\
\hline & Média & Máximo & Média & Máximo & Média & Máximo \\
\hline 0,25 & $74,34 \pm 36,91$ & 145,15 & $105,24 \pm 29,54$ & 145,15 & $55,02 \pm 26,69$ & 98,23 \\
\hline 0,5 & $124,78 \pm 71,82$ & 289,77 & $132,88 \pm 93,47$ & 289,77 & $117,42 \pm 48,27$ & 188,80 \\
\hline 1,0 & $96,57 \pm 51,02$ & 168,04 & $93,46 \pm 55,54$ & 157,88 & $98,64 \pm 49,68$ & 168,04 \\
\hline 2,0 & $73,49 \pm 60,48$ & 193,67 & $119,09 \pm 53,58$ & 193,67 & $47,10 \pm 47,88$ & 140,07 \\
\hline
\end{tabular}

Tabela 5.15 - Resumo do teste ANOVA: Fator único para a produção volumétrica de hidrogênio (HPR).

\begin{tabular}{|c|c|c|c|c|c|c|}
\hline & & & & & & \\
\hline & Grupo & Contagem & Soma & Média & Variância & \\
\hline & $\mathrm{R}=0,25$ & 26 & 1932.79 & 74.34 & 1362.34 & \\
\hline & $\mathrm{R}=0,5$ & 21 & 2620.37 & 124.78 & 5158.55 & \\
\hline & $\mathrm{R}=1,0$ & 25 & 2414.24 & 96.57 & 2603.37 & \\
\hline & $\mathrm{R}=2,0$ & 30 & 2204.84 & 73.49 & 3657.73 & \\
\hline $\begin{array}{l}\text { Fonte da } \\
\text { variaçãoo }\end{array}$ & $S Q$ & $g l$ & $M Q$ & $F$ & valor-P & F crítico \\
\hline Entre & & & & & & \\
\hline grupos & 41031.04 & 3 & 13677.01 & 4.38 & 0.01 & 2.70 \\
\hline Dentro dos & & & & & & \\
\hline grupos & 305784.4 & 98 & 3120.25 & - & - & - \\
\hline Total & 346815.4 & 101 & - & - & - & - \\
\hline
\end{tabular}


Tabela 5.16 - Resumo do Teste Tukey para a produção volumétrica de hidrogênio (HPR)

$\begin{array}{ccccc} & \mathrm{R}=0,25 & \mathrm{R}=0,5 & \mathrm{R}=1,0 & \mathrm{R}=2,0 \\ \mathrm{R}=0,25 & - & 0.014257 & 0.489567 & 0.999944 \\ \mathrm{R}=0,5 & 0.014257 & - & 0.326151 & 0.009172 \\ \mathrm{R}=1,0 & 0.489567 & 0.326151 & - & 0.426406 \\ \mathrm{R}=2,0 & 0.999944 & 0.009172 & 0.426406 & -\end{array}$

Os resultados obtidos apresentaram valores máximos superiores aos obtidos no trabalho de Rojas (2010) (162,50 mL de $\left.\mathrm{H}_{2} \cdot \mathrm{h}^{-1} \cdot \mathrm{L}^{-1}\right)$, realizado no mesmo tipo de reator com o mesmo substrato e mesma carga orgânica. Os valores máximos obtidos no presente trabalho apresentaram-se abaixo dos obtidos por Peixoto (2008) que apesar de ter trabalhado em um reator similar utilizou uma água residuária diferente, que simulava despejo de indústria de refrigerante.

Para todos os parâmetros analisados ficou clara a influência da taxa de recirculação sobre todos os parâmetros previamente analisados. A recirculação pode ter efeitos positivos e negativos no desempenho de um reator. Tendo em vista isto, era esperada a existência de um ponto de ótimo, o que provavelmente ocorreu. Com base nos parâmetros analisados é possível afirmar que a razão de recirculação de 0,5 gerou os melhores resultados. No entanto, é possível se buscar um ponto de ótimo operacional. Para isso, foi utilizado o rendimento máximo $\left(\mathrm{Y}_{\mathrm{H} 2}\right)$ como parâmetro para avaliação do ponto ótimo de operação desse reator. Inicialmente, foi relacionado $\mathrm{Y}_{\mathrm{H} 2}$ com o número de reatores de mistura em série $(\mathrm{N})$ conforme dados da Tabela 5.11 (Figura 5.8) e ajustou-se uma função polinomial para descrever essa variação com a finalidade de se obter o valor $\mathrm{N}$ que fornece o máximo valor de $\mathrm{Y}_{\mathrm{H} 2}$. Para a função ajustada chegou-se, a partir de derivação da função polinomial para busca do ponto de máximo, a um ponto ótimo de 4,22 $\mathrm{mmol} \mathrm{H}_{2} \cdot \mathrm{mol} \mathrm{sac}^{-1}$, que seria obtido para um $\mathrm{N}$ de 8 . Esse 
valor de $\mathrm{N}$ está relacionado com uma razão de recirculação de 0,6 , obtido a partir da relação entre N e R (Figura 5.9), a partir de dados da Tabela 5.1.

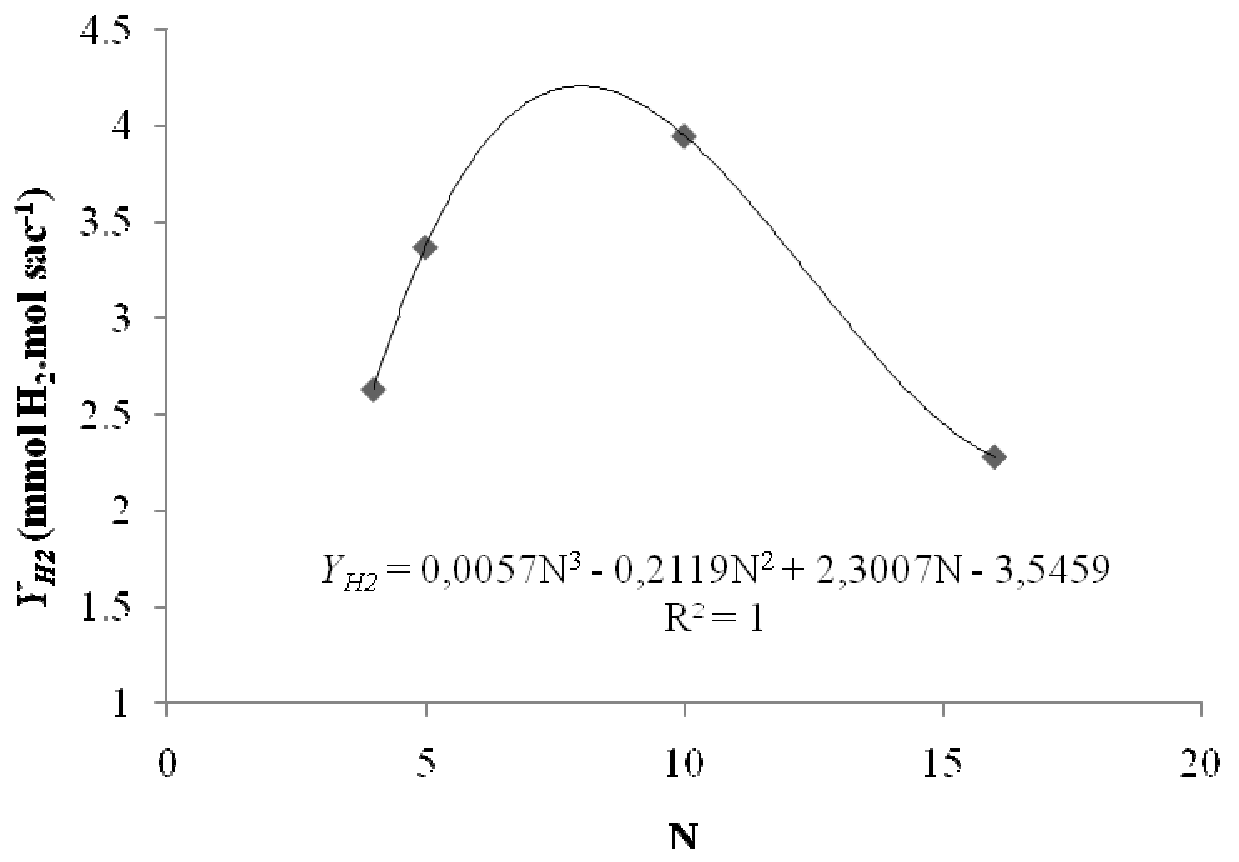

Figura 5.8 - Relação entre $\mathbf{Y}_{\mathrm{H} 2}$ e $N$

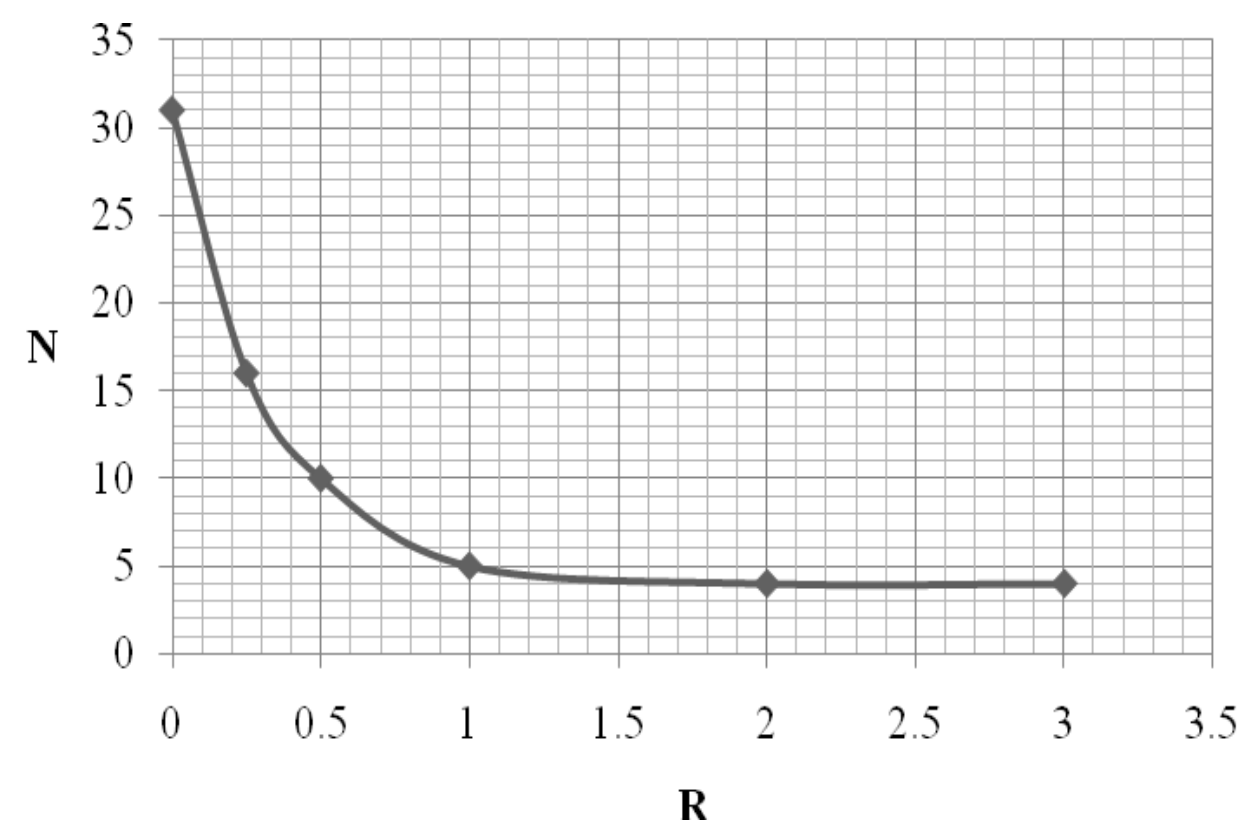

Figura 5.9 - Relação entre N e a razão de recirculação (R) 
Da mesma forma, ajustou-se uma função polinomial para a produção volumétrica de hidrogênio (HPR) média. O valor ótimo obtido foi de $128,13 \mathrm{~mL} \mathrm{H}_{2} \cdot \mathrm{h}^{-1} \mathrm{~L}^{-1}$, também para $\mathrm{N}=8$ (Figura 5.10). Com a Figura 5.9, chegou-se a $\mathrm{R}=0,6$ como ponto ótimo mais uma vez.

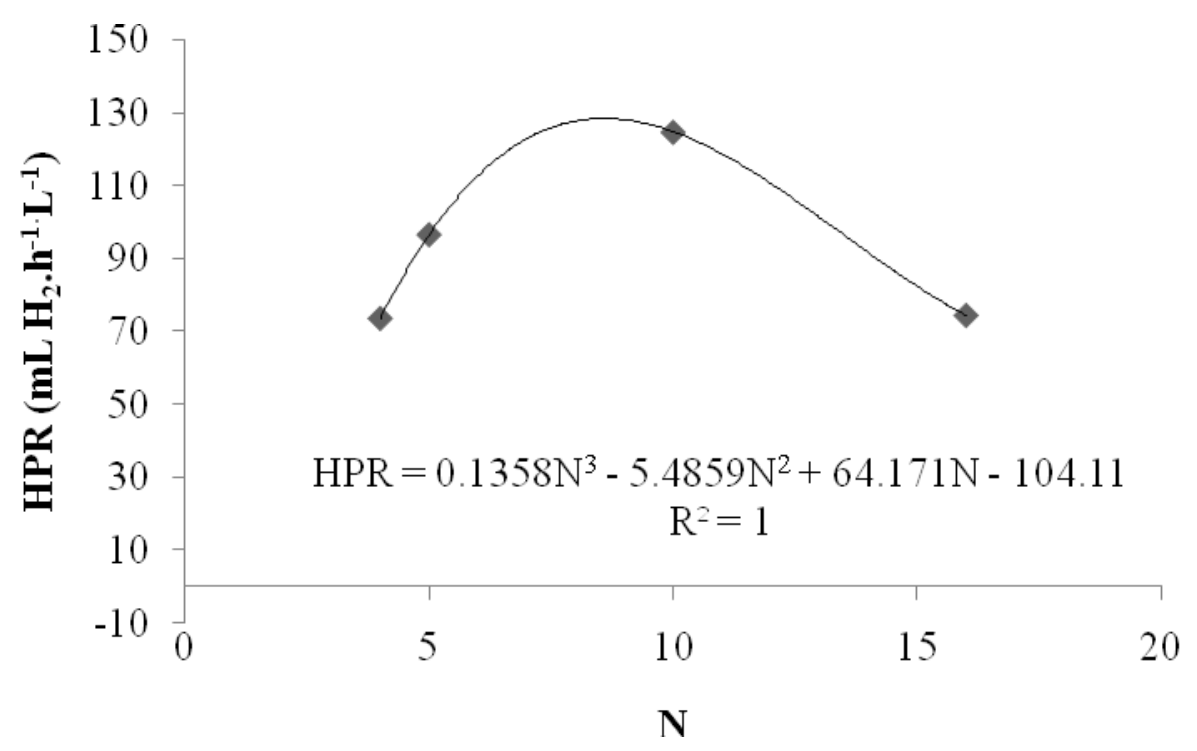

Figura 5.10 - Relação entre HPR e N

$\mathrm{O}$ aumento da recirculação aumenta a velocidade do líquido no reator $\mathrm{e}$ conseqüentemente melhora a transferência de massa do estado líquido para o estado gasoso. Com isso ocorre uma maior liberação do hidrogênio (que é produzido no meio líquido) para o meio gasoso. De acordo com Pauss et al. (1990), esse coeficiente de transferência de massa líquido-gás é muito baixo podendo ocorrer concentrações de hidrogênio no meio líquido próximas a 70 vezes os valores no equilíbrio termodinâmico. A recirculação aumentaria esse coeficiente de transferência de massa.

Em seu trabalho, Lamed et al. (1988) sugeriu que a saturação de hidrogênio no meio líquido atua de maneira importante na produção de intermediários. Com a recirculação, ocorreria uma liberação desse hidrogênio em excesso no meio líquido, evitando assim deslocamentos de equilíbrios químicos de reações como a de produção de ácido acético a 
partir de sacarose e diminuindo possíveis inibições causadas por altas concentrações de $\mathrm{H}_{2}$ no meio.

Ainda existe o fato que com a melhoria da transferência de massa, ocorre uma melhoria na transferência do meio líquido para a biomassa, ocorrendo assim uma melhor degradação do substrato e melhor produção de hidrogênio.

As três hipóteses acima podem ter sido predominantes na faixa de operação abaixo de $\mathrm{R}=0,6$ e explicar o aumento nos parâmetros analisados. Porém a partir de $\mathrm{R}=0,6$ (que seria o ponto ótimo operacional), os parâmetros decaem. Algumas explicações podem ser dadas para este fato.

Rodrigues et al. (2003) encontraram um ponto de agitação ótimo, acima do qual a eficiência do processo caiu devido a uma dispersão do crescimento da biomassa ocasionada por uma mistura excessiva. Poderia ocorrer que altas razões de recirculação arrastassem biomassa e com isso ocorresse uma queda dos parâmetros analisados. Esta hipótese pôde ser negada no presente trabalho através da análise dos sólidos suspensos voláteis (SSV) no efluente do reator (Figura 5.11 e Tabela 5.17). 


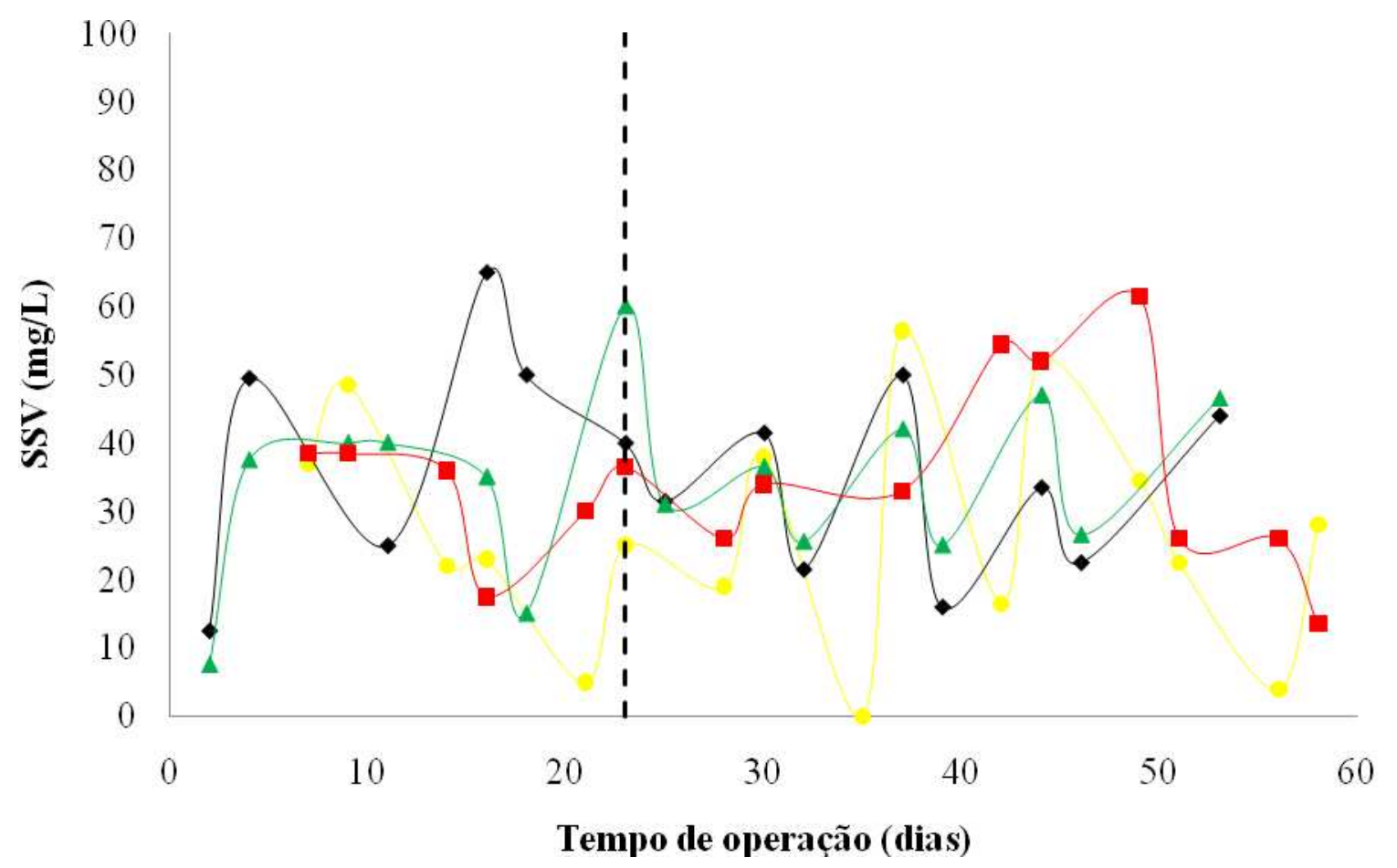

Figura 5.11 - Concentração dos sólidos suspensos voláteis (SSV) para $R=0,25$ ( ), R=0,5 ( $)$, $R=1,0(\Delta)$ e $R=2,0(\square)$

Tabela 5.17 - Valores médios dos sólidos suspensos voláteis (SSV) no efluente dos reatores. SSV (mg.. $\left.{ }^{-1}\right)$

\begin{tabular}{lc}
\hline Recirculação & Média \\
\hline R0,25 & $26,97 \pm 16,77$ \\
R0,5 & $35,89 \pm 15,24$ \\
R1,0 & $34,33 \pm 13,19$ \\
R2,0 & $34,90 \pm 13,20$ \\
\hline
\end{tabular}

Através de análises estatísticas (ANOVA e Teste Tukey, Tabelas 5.18 e 5.19, respectivamente), obteve-se que os dados obtidos para SSV nas operações não apresentam diferenças significativas. Com isso, não ocorreu uma mudança significativa de biomassa entre as fases de operação e a hipótese de arraste de biomassa pode ser refutada. 
Tabela 5.18 - Resumo do teste ANOVA: Fator único para a concentração dos sólidos suspensos voláteis (SSV)

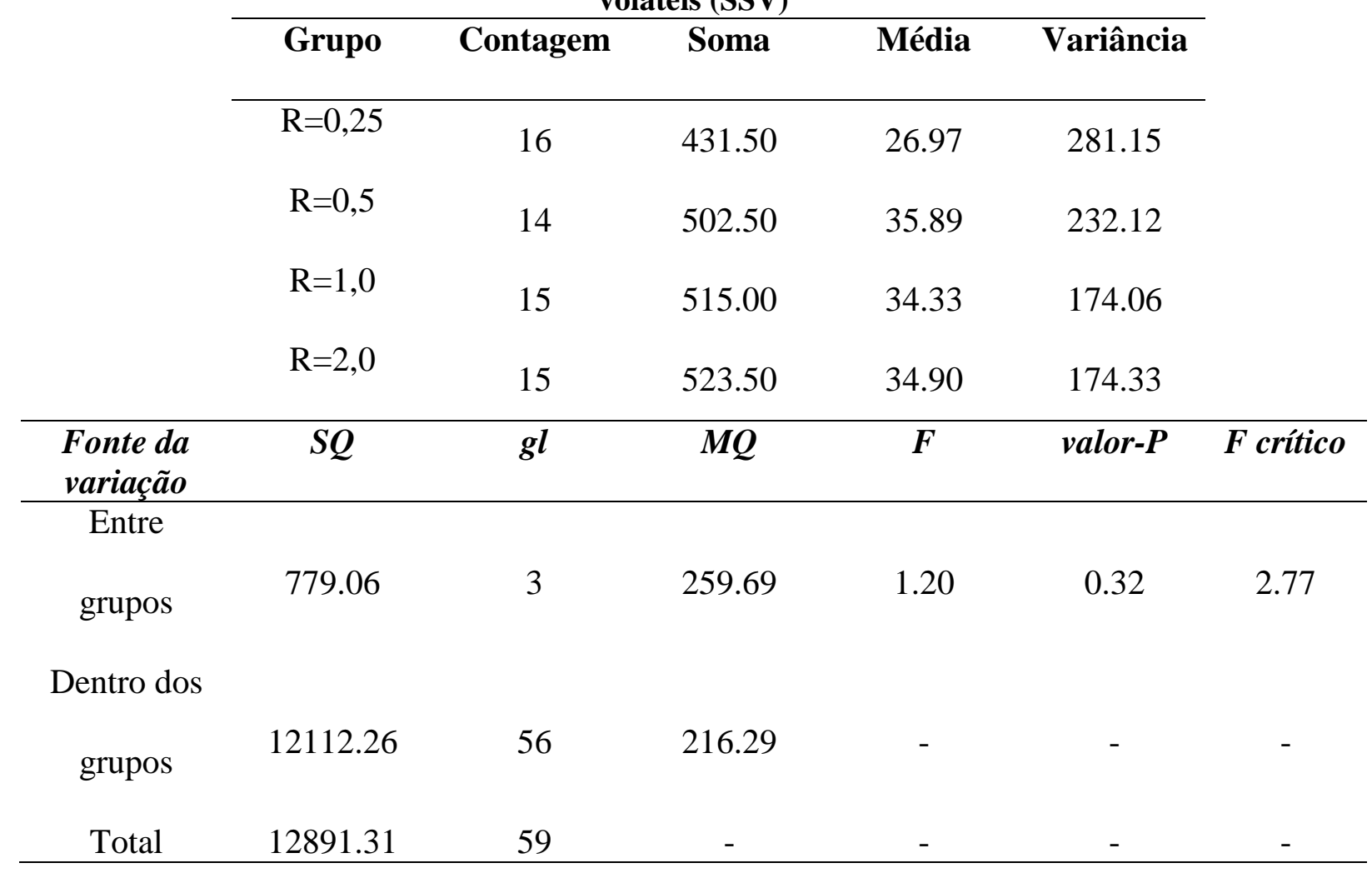

Tabela 5.19 - Resumo do Teste Tukey para a concentração dos sólidos suspensos voláteis (SSV)

$$
\mathrm{R}=0,25 \quad \mathrm{R}=0,5 \quad \mathrm{R}=1,0 \quad \mathrm{R}=2,0
$$

$\begin{array}{ccccc}\mathrm{R}=0,25 & - & 0.355392 & 0.508837 & 0.444086 \\ \mathrm{R}=0,5 & 0.355392 & - & 0.991884 & 0.997904 \\ \mathrm{R}=1,0 & 0.508837 & 0.991884 & - & 0.999626 \\ \mathrm{R}=2,0 & 0.444086 & 0.997904 & 0.999626 & -\end{array}$

De acordo com Levenspiel (2000), regimes hidrodinâmicos de mistura completa inibem a formação de todos os intermediários das reações processadas (isso inclui o próprio hidrogênio formado, os álcoois e os solventes), enquanto que regimes hidrodinâmicos pistonados fornecem a maioria destes produtos intermediários das reações envolvidas. Com o aumento da recirculação ocorreu um distanciamento do regime pistonado e uma aproximação 
do regime de mistura completa. Provavelmente esta hipótese foi predominante na faixa de operação acima de 0,6 .

\subsection{Geração de produtos de fermentação em meio líquido}

Pode-se observar que para todas as taxas de recirculação estudadas (Figura 5.12 e 5.13) houve predominância do ácido acético, ácido butírico e etanol. Além deles, outros produtos intermediários como ácido propiônico, n-butanol, acetona, ácido isobutírico, metanol, ácido capróico, ácido valérico ácido isovalérico foram gerados, porém em quantidades menores do que $50 \mathrm{mg} . \mathrm{L}^{-1}$ (Tabela 5.20 e Figura 5.14). 

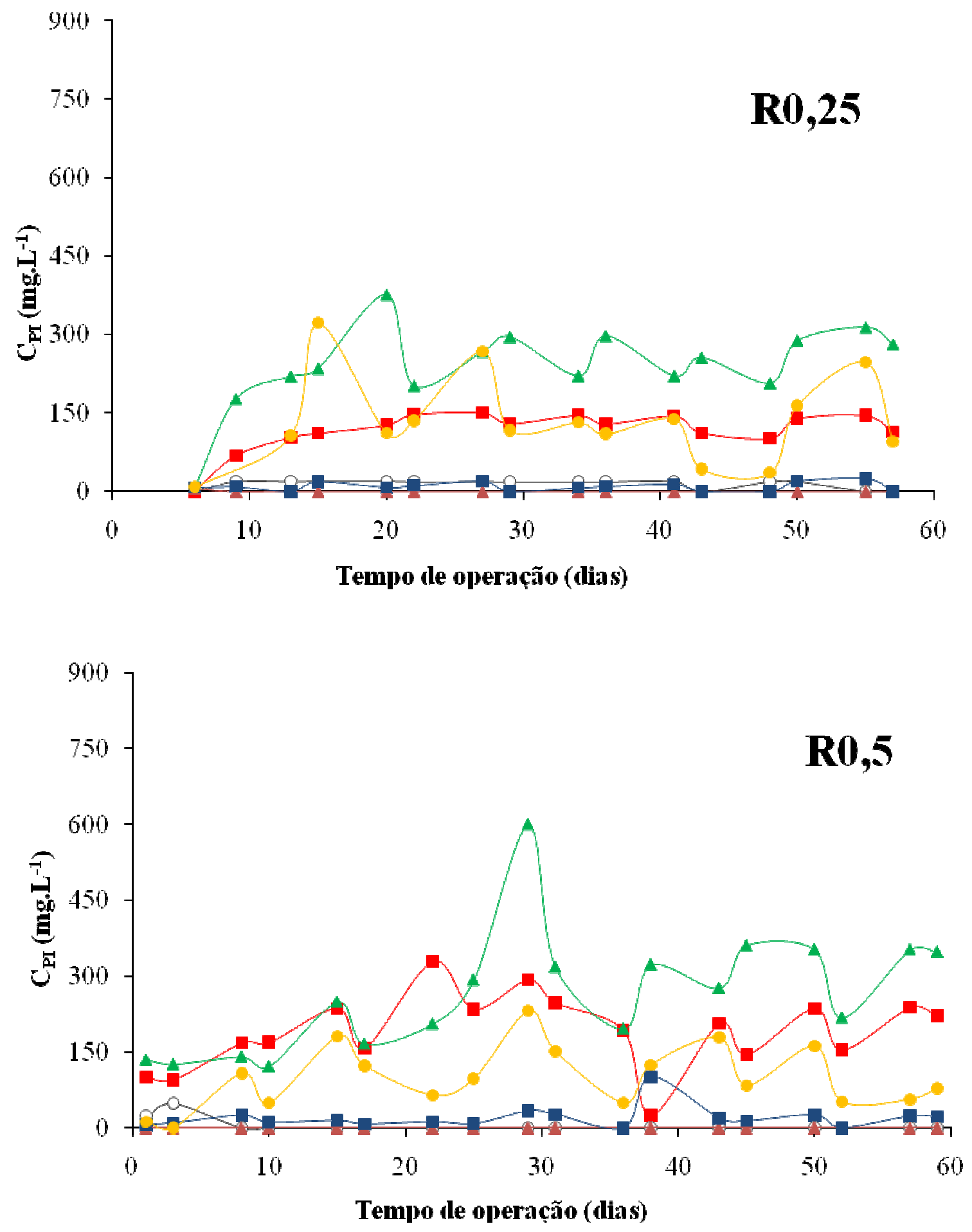

Figura 5.12 - Geração de produtos intermediários $\left(C_{P I}\right)$ para $R=0,25$ e $R=0,5$ - ( $\Delta$ ) Ácido acético, ( $($ ) Etanol, ( ) Ácido butírico, ( $(\Delta)$ n-Butanol, ( $(\square)$ Ácido propiônico, ( ( ) Acetona. 

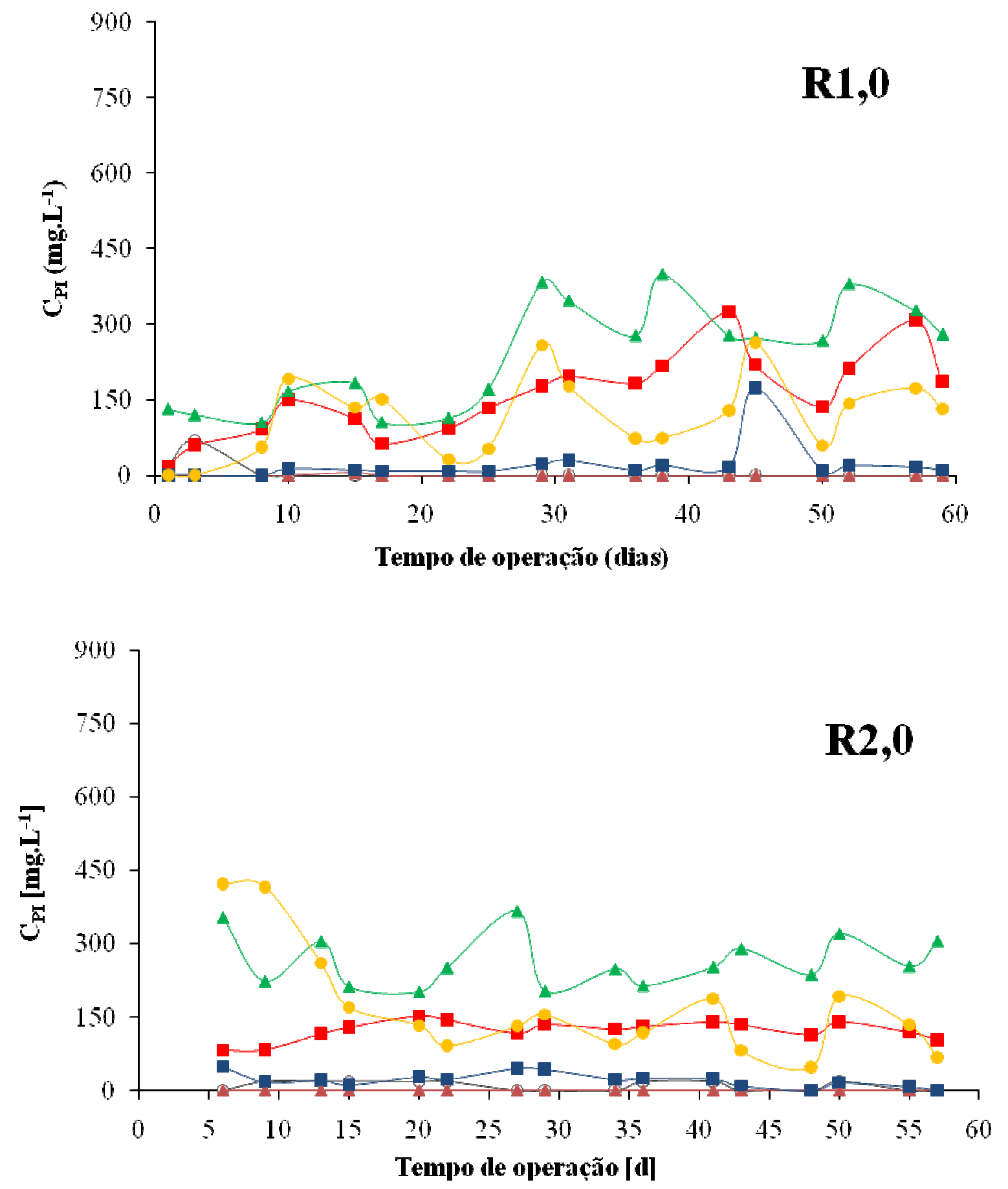

Figura 5.13 - Geração de produtos intermediários $\left(C_{\mathrm{PI}}\right)$ para $R=1,0$ e $R=2,0$ - ( $\Delta$ ) Ácido acético, (匹) Etanol, ( ) Ácido butírico, ( $(\Delta)$ n-Butanol, ( ( ) Ácido propiônico, ( $(\circ)$ Acetona. 
Tabela 5.20 - Concentração média dos produtos intermediários $\left(C_{\mathrm{PI}}\right)$ gerados na fermentação do hidrogênio

\begin{tabular}{ccccc}
\hline Produtos & \multicolumn{4}{c}{ Concentração média $\left(\mathbf{m g} . \mathbf{L}^{-\mathbf{1}}\right)$} \\
\cline { 2 - 5 } intermediários & $\mathbf{R = 0 , 2 5}$ & $\mathbf{R}=\mathbf{0 , 5}$ & $\mathbf{R = 1 , 0}$ & $\mathbf{R = 2 , 0}$ \\
\hline Acetona & $14.11 \pm 8,42$ & $4.01 \pm 12.41$ & $4.68 \pm 16.31$ & $9.26 \pm 9.56$ \\
Metanol & $0.00 \pm 0.00$ & $0.49 \pm 2.08$ & $0.00 \pm 0.00$ & $0.00 \pm 0.00$ \\
Etanol & $116.70 \pm 38.20$ & $191.87 \pm 73.67$ & $160.24 \pm 81.91$ & $123.00 \pm 20.50$ \\
n-Butanol & $0.30 \pm 1.21$ & $0.00 \pm 0.00$ & $0.30 \pm 1.10$ & $0.00 \pm 0.00$ \\
Ac. Acético & $241.28 \pm 80.66$ & $265.61 \pm 119.46$ & $239.09 \pm 103.56$ & $265.00 \pm 52.54$ \\
Ac. Propiônico & $9.00 \pm 8.10$ & $20.01 \pm 22.32$ & $20.61 \pm 38.97$ & $21.50 \pm 14.80$ \\
Ac. Isobutírico & $0.45 \pm 1.81$ & $8.40 \pm 8.10$ & $34.50 \pm 95.80$ & $0.69 \pm 2.77$ \\
Ac. Butirico & $135.37 \pm 86.42$ & $100.00 \pm 62.59$ & $116.46 \pm 78.94$ & $168.90 \pm 111.03$ \\
Ac. Isovalérico & $0.50 \pm 2.10$ & $3.00 \pm 0.58$ & $4.44 \pm 5.51$ & $0.00 \pm 0.00$ \\
Ac. Valérico & $0.00 \pm 0.00$ & $8.00 \pm 5.00$ & $10.10 \pm 15.00$ & $0.00 \pm 0.00$ \\
Ac. Capróico & $0.00 \pm 0.00$ & $5.02 \pm 1.23$ & $8.65 \pm 15.98$ & $0.00 \pm 0.00$ \\
\hline & & & & \\
\hline
\end{tabular}




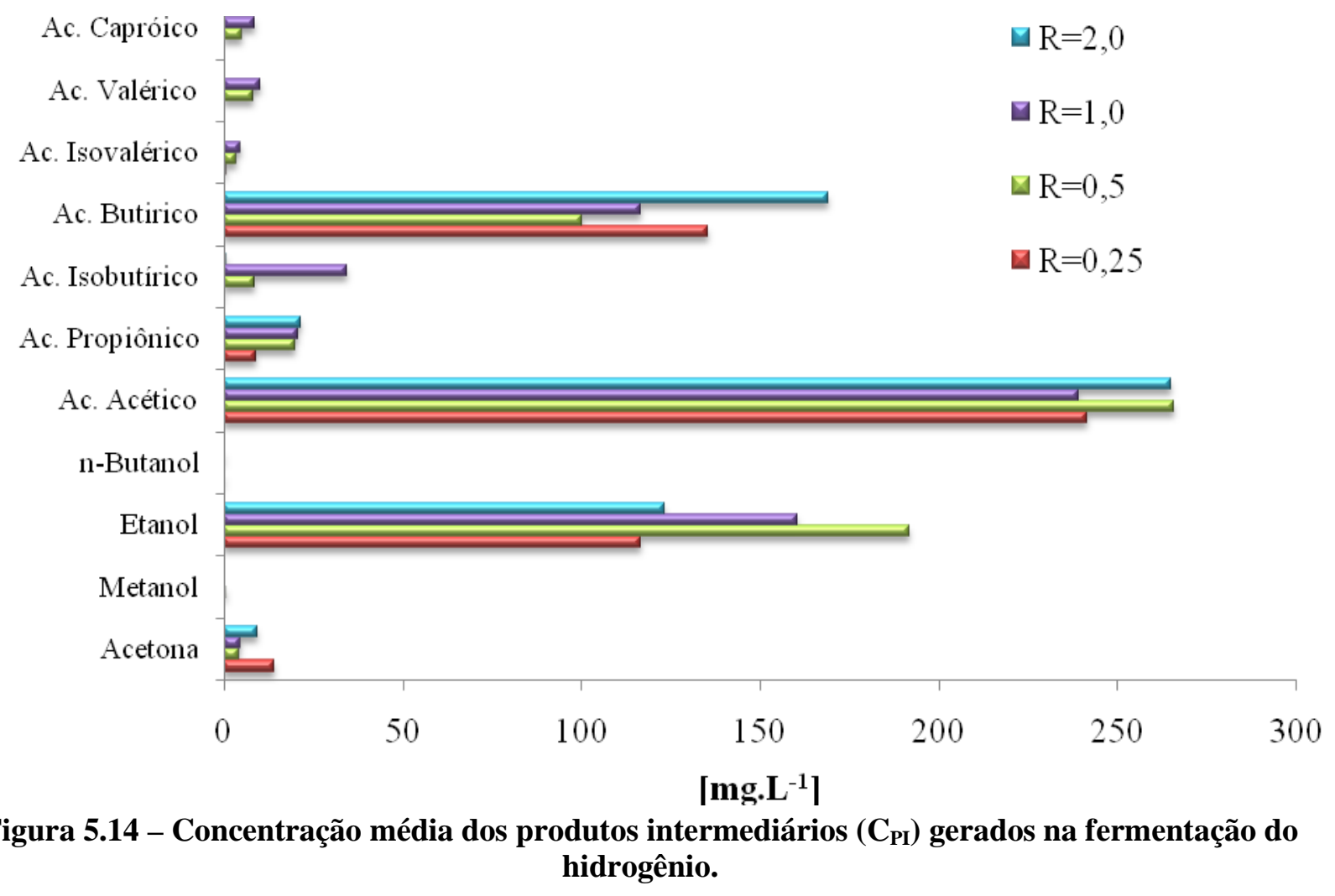

A distribuição dos produtos intermediários não apresentou uma diferenciação clara entre as diferentes fases de operação. $\mathrm{O}$ ácido acético e butírico tem destaque em todas as fases, assim como o etanol, sendo que os dois primeiros são indicadores de máxima produção de hidrogênio (Levin et al., 2004).

A formação dos produtos intermediários no presente trabalho coincidiu, nos tipos produzidos, com diversas pesquisas sobre produção biológica de hidrogênio. As quantidades e a distribuição, porém, não foram similares devido às diferentes configurações de reatores e parâmetros operacionais utilizados em cada trabalho (Fernandes, 2008; Peixoto, 2008, OThong et al., 2008; Fritsch, et al., 2008; Amorim, 2009; Maintinguer et al., 2009, Barros, 2009; Rojas, 2010; Reis, 2010).

A Figura 5.15 representa a porcentagem média de distribuição de cada um dos ácidos em cada fase de operação. O ácido acético, como apresentado anteriormente, foi o principal metabolito com porcentagens variando entre $65,1 \%$ para $\mathrm{R} 1,0$ e $73,3 \%$ para $\mathrm{R}=0,5$ (que foi a 
melhor condição de operação para os outros parâmetros analisados), seguido pelo ácido butírico com porcentagens variando entre $18,8 \%$ para $\mathrm{R}=0,5$ e $28,9 \%$ para $\mathrm{R}=2,0$. Esta distribuição é similar à encontrada por Fernandes (2008), Maintinguer et al. (2008) e Rojas (2010).

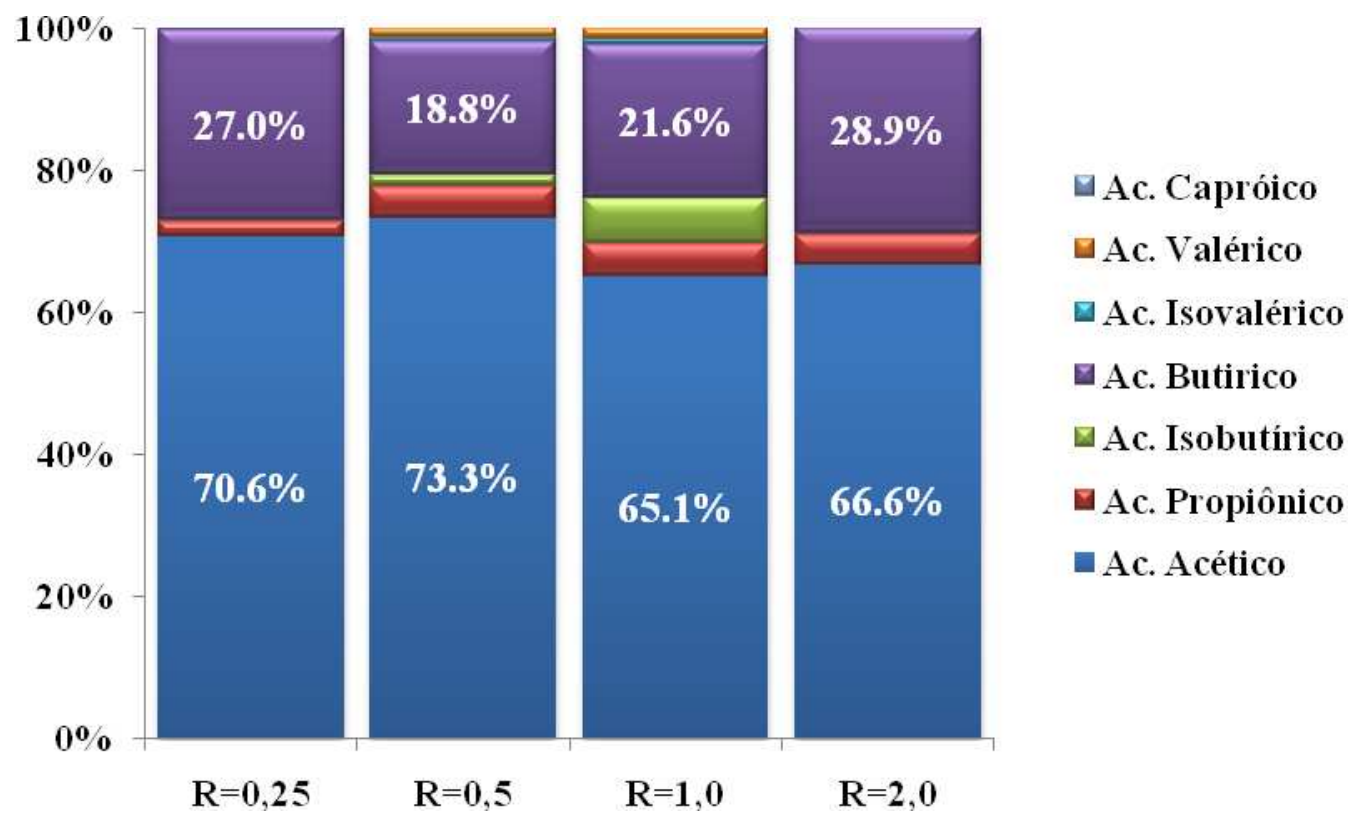

Figura 5.15 - Distribuição percentual média dos ácidos no meio líquido

A Figura 5.16 apresenta as porcentagens médias de distribuição de solventes formados (álcoois e acetona), sendo o etanol o principal produto com valores entre 91,1\% para R0,25 e 98\% para R0,5. Estes valores coincidiram com o trabalho de Fernandes (2008), Rojas (2010) e Peixoto (2008). 


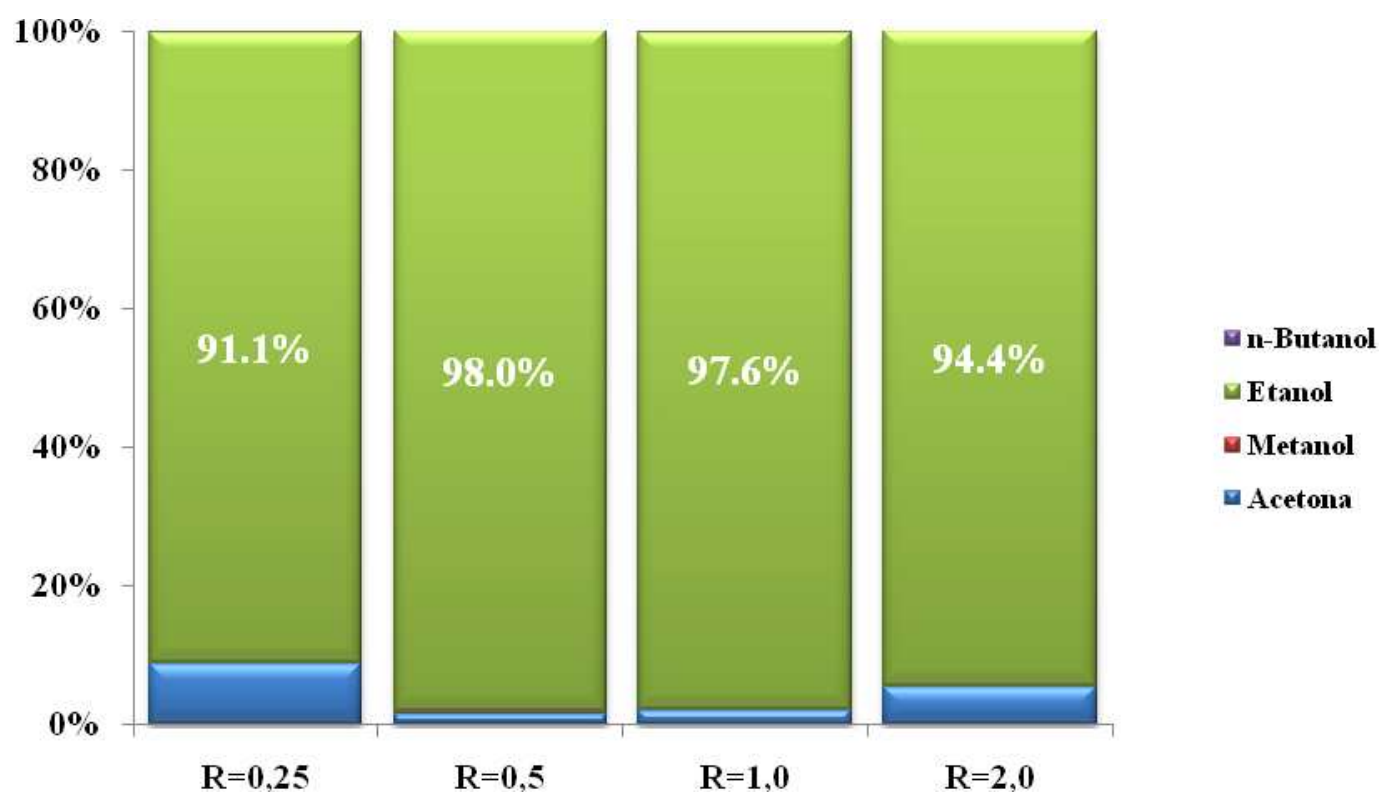

Figura 5.16 - Distribuição percentual média dos alcoois e acetona no meio líquido

A remoção de DQO está representada na Figura 5.17 e na Tabela 5.22. Os valores médios ficaram próximos de $20 \%$, se mantendo constante durante toda a operação, como esperado para o processo de produção de hidrogênio por degradação anaeróbia.

O balanço da DQO foi realizado para todas as operações da seguinte maneira: com as reações químicas listadas abaixo (Equações 5.1 a 5.4), nas quais se encontram apenas os metabolitos mais significativos, calculou-se a DQO para os produtos intermediários efluentes. Somou-se a esses valores a DQO da sacarose efluente (Equação 5.5) e da biomassa desprendida do material suporte (Equação 5.6). Este valor deveria estar o mais próximo possível da DQO efluente.

$\mathrm{CH}_{3} \mathrm{COOH}($ ac. acético $)+2 \mathrm{O}_{2} \rightarrow 2 \mathrm{CO}_{2}+2 \mathrm{H}_{2} \mathrm{O}$

(Equação5.1)

$\mathrm{DQO}=1,006 \mathrm{~g} \mathrm{O}_{2} / \mathrm{g}$ ac. acético 
$\mathrm{CH}_{3} \mathrm{CH}_{2} \mathrm{CH}_{2} \mathrm{COOH}$ (ac. butírico) $+5 \mathrm{O}_{2} \rightarrow 4 \mathrm{CO}_{2}+4 \mathrm{H}_{2} \mathrm{O}$

(Equação5.2)

DQO $=1,818 \mathrm{~g} \mathrm{O}_{2} / \mathrm{g}$ ac. butírico

$\mathrm{CH}_{3} \mathrm{CH}_{2} \mathrm{COOH}$ (ac. propiônico) $+7 / 2 \mathrm{O}_{2} \rightarrow 3 \mathrm{CO}_{2}+3 \mathrm{H}_{2} \mathrm{O}$

(Equação5.3)

$\mathrm{DQO}=1,5135 \mathrm{~g} \mathrm{O}_{2} / \mathrm{g}$ ac. propiônico

$\mathrm{C}_{2} \mathrm{H}_{6} \mathrm{O}($ etanol $)+2 \mathrm{O}_{2} \rightarrow 2 \mathrm{CO}_{2}+3 \mathrm{H}_{2} \mathrm{O}$

(Equação5.4)

$\mathrm{DQO}=1,391 \mathrm{~g} \mathrm{O}_{2} / \mathrm{g}$ etanol

$\mathrm{C}_{12} \mathrm{H}_{22} \mathrm{O}_{11}$ (sacarose) $+12 \mathrm{O}_{2} \rightarrow 12 \mathrm{CO}_{2}+11 \mathrm{H}_{2} \mathrm{O}$

(Equação5.5)

$\mathrm{DQO}=1,123 \mathrm{~g} \mathrm{O}_{2} / \mathrm{g}$ sacarose

$\mathrm{C}_{5} \mathrm{H}_{9} \mathrm{O}_{3} \mathrm{~N}$ (biomassa) $+11 / 2 \mathrm{O}_{2} \rightarrow 5 \mathrm{CO}_{2}+9 / 2 \mathrm{H}_{2} \mathrm{O}$

(Equação5.6)

$\mathrm{DQO}=1,343 \mathrm{~g} \mathrm{O}_{2} / \mathrm{g}$ biomassa 


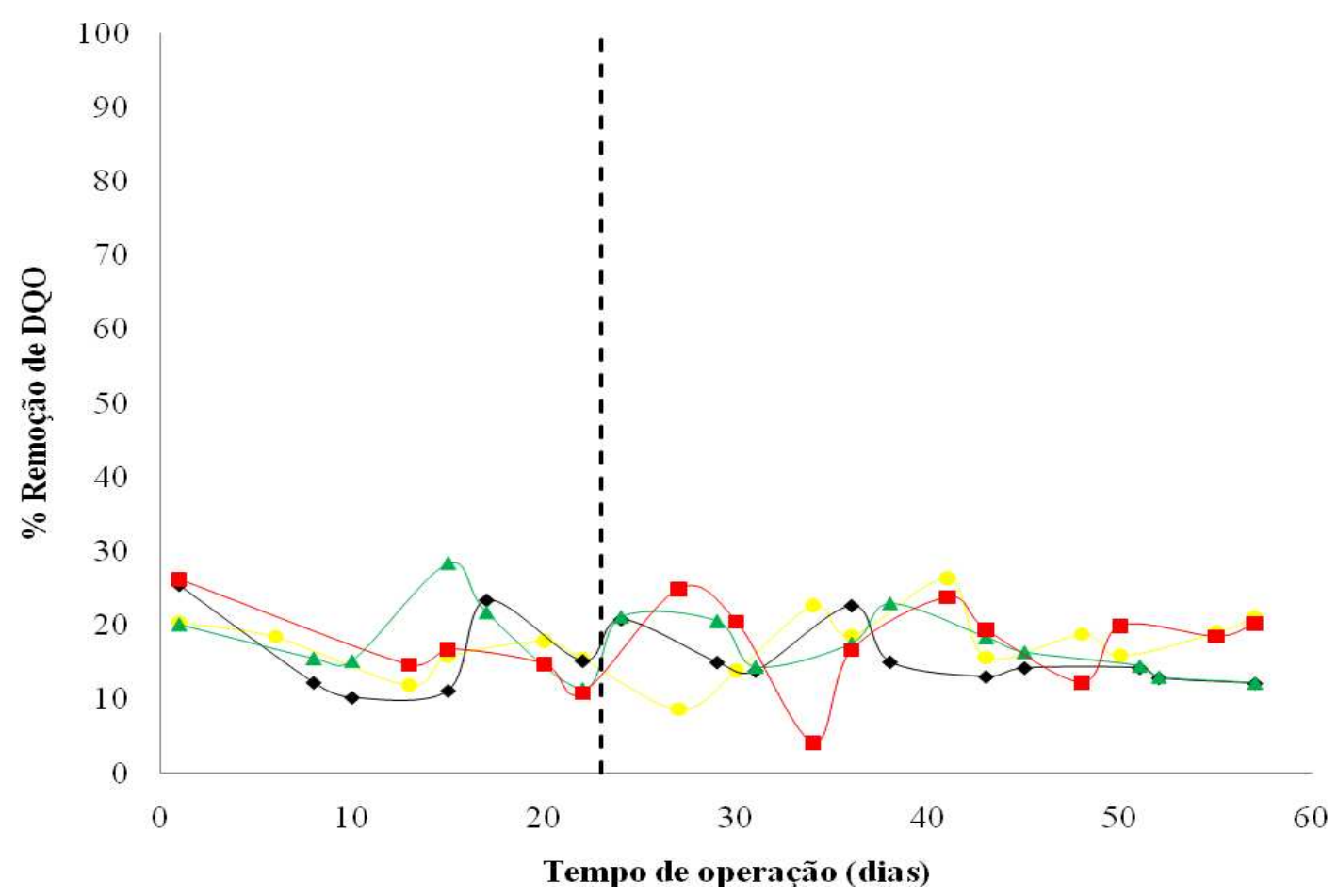

Figura 5.17 - Eficiência de remoção de DQO para $R=0,25$ ( $), R=0,5$ ( $), R=1,0$ ( $\triangle$ ) e R=2,0 ( $\square$ )

Tabela 5.21 - Valores médios e máximos de eficiência de remoção de DQO.

\begin{tabular}{lcc}
\hline $\mathbf{R}$ & Média & Máximo \\
\hline 0,25 & $17,54 \pm 4,24$ & 26,35 \\
0,5 & $15,42 \pm 4,69$ & 25,44 \\
1,0 & $17,33 \pm 4,70$ & 28,41 \\
2,0 & $17,53 \pm 5,76$ & 26,17 \\
\hline
\end{tabular}

A Tabela 5.23 apresenta os valores médios da DQO efluente, da somatória da DQO dos produtos intermediários com a DQO da sacarose efluente e com a DQO da biomassa desprendida do material suporte (obtida através dos sólidos suspensos voláteis) e o desvio entre o primeiro e o segundo. A concordância deve sempre ser o mais próximo possível de $100 \%$, para fechar o balanço. Os valores obtidos em cada fase se distanciaram desse valor, o 
que indica que possivelmente ainda existem metabólitos não detectados pelos métodos de análise utilizados que podem ser levados em consideração.

Tabela 5.22 - Balanço da DQO efluente.

\section{DQO Produtos}

\begin{tabular}{cccc}
$\mathbf{R}$ & DQO Efluente (I) & $\begin{array}{c}\text { intermediários }+ \\
\text { DQO Sacarose } \\
\text { efluente (II) }\end{array}$ & $\begin{array}{c}\text { \% de concordância } \\
\text { entre (I) e (II) }\end{array}$ \\
\hline 0,25 & 1691.00 & 1314.20 & $80 \%$ \\
0,5 & 1533.91 & 1133.13 & $77 \%$ \\
1,0 & 1624.33 & 1391.19 & $75 \%$ \\
\hline
\end{tabular}

\subsection{Análises de microscopia ótica}

As análises microscópicas foram realizadas com amostras retiradas do reator no final dos 60 dias de operação. Estas análises apresentaram bacilos, endosporos e leveduras, como pode se observar na Figura 5.18. Estes resultados apresentam grande similaridade com as análises microscópicas realizadas por Fernandes (2008), Peixoto (2008) e Maintinger et al. (2008). Levando em consideração a semelhança de configuração dos reatores utilizados nestes trabalhos, é possível inferir que os resultados obtidos pela biologia molecular destes pode se encaixar com o presente trabalho, com isso os microrganismos encontrados provavelmente pertencem aos gêneros Clostridium, Enterobacter ou Klebsiella. 


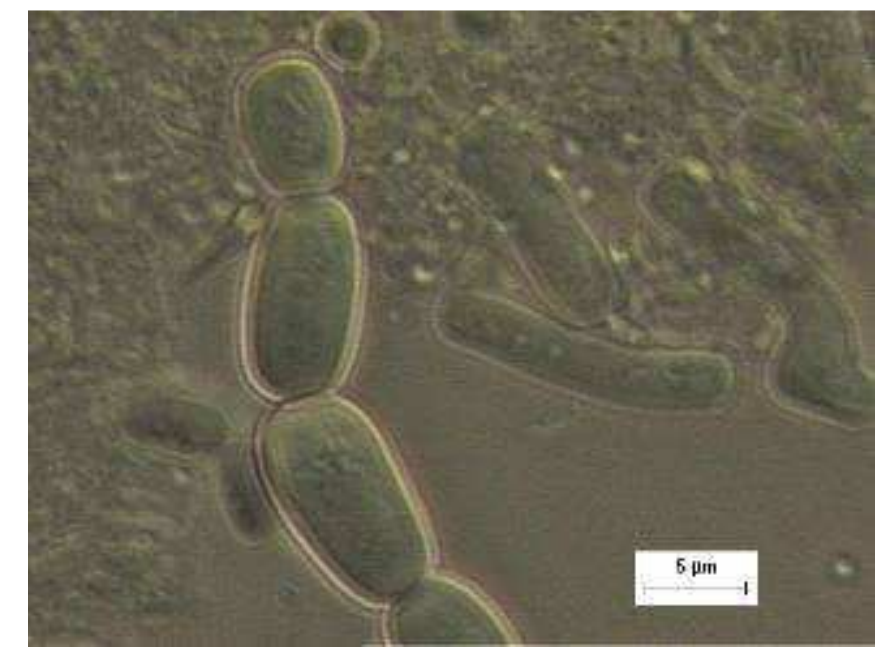

(a)

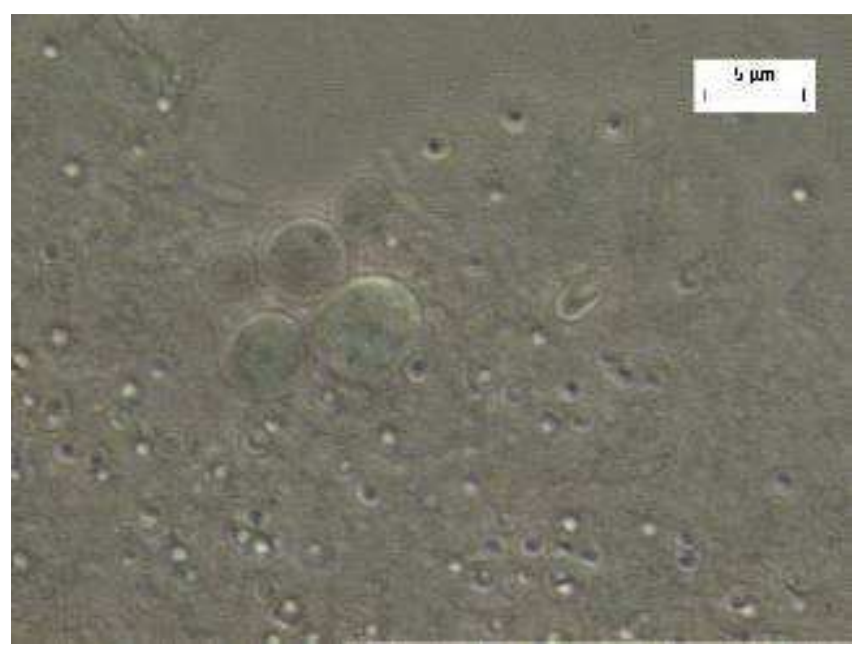

(c)

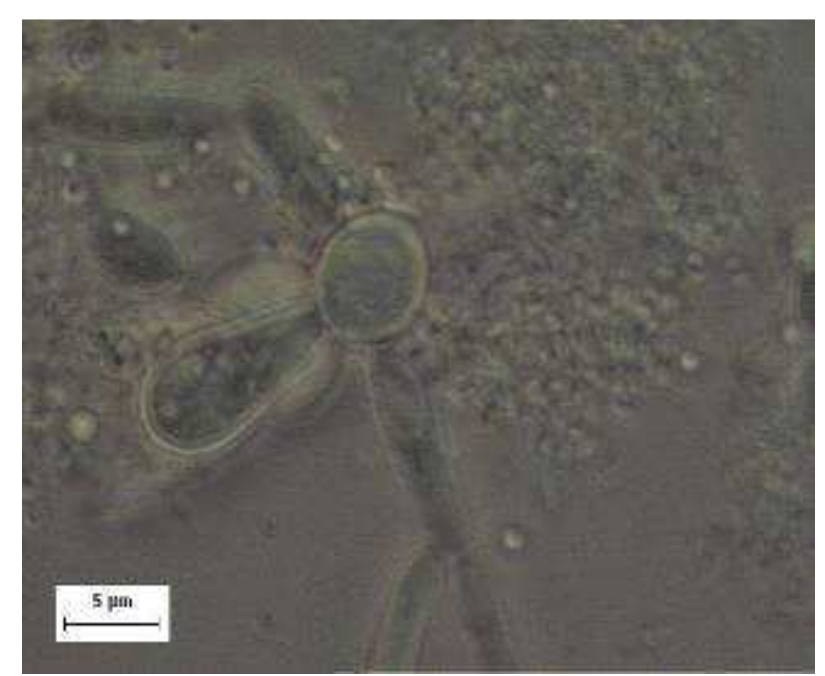

(b)

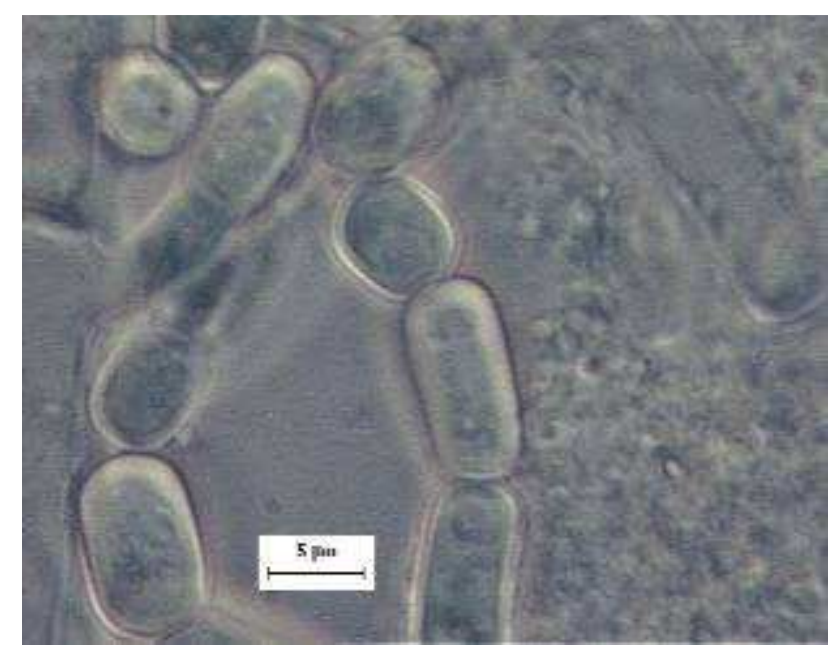

(d)

Figura 5.18 - Análise microscópica de amostras presentes em: (a) R=0,25; (b) R=0,5; (c) R=1,0 e (d) $\mathbf{R}=\mathbf{2 , 0}$

Levando em consideração os produtos intermediários que apresentaram os maiores valores de produção (ácido acético, ácido butírico e etanol) é possível associar a presença do Clostridium acetobutylicum nos reatores operados. A fermentação por este microrganismo acontece em duas fases, sendo a primeira caracterizada pelo rápido crescimento e pelas elevadas velocidades de produção de hidrogênio junto com a produção dos ácidos acético e butírico. A segunda fase é caracterizada por um crescimento mais lento com baixa produção de hidrogênio e pela produção de solventes como o etanol (Mathews e Wang, 2009). 


\subsection{Instabilidade na produção de hidrogênio}

A instabilidade na produção do biogás, do rendimento e da produção volumétrica de hidrogênio, como destacado anteriormente, foi algo que aconteceu em todas as fases de operação. Esta mesma instabilidade já havia sido observada por Fernandes (2008) e Rojas (2010), que operaram reatores com condições similares à do presente trabalho.

Este comportamento instável não se apresentou no meio líquido. Através da remoção de sacarose e da geração dos produtos solúveis foi possível observar que o processo se estabilizou à partir do $23^{\circ}$ dia e se manteve desta forma até o final da operação. $\mathrm{O}$ pH efluente também se manteve constante, sempre próximo a 4,5, em todas as fases (Figura 5.19 e Tabela 5.24). Com isso pode-se concluir que aparentemente não ocorreu nenhuma mudança de rota metabólica durante o experimento.

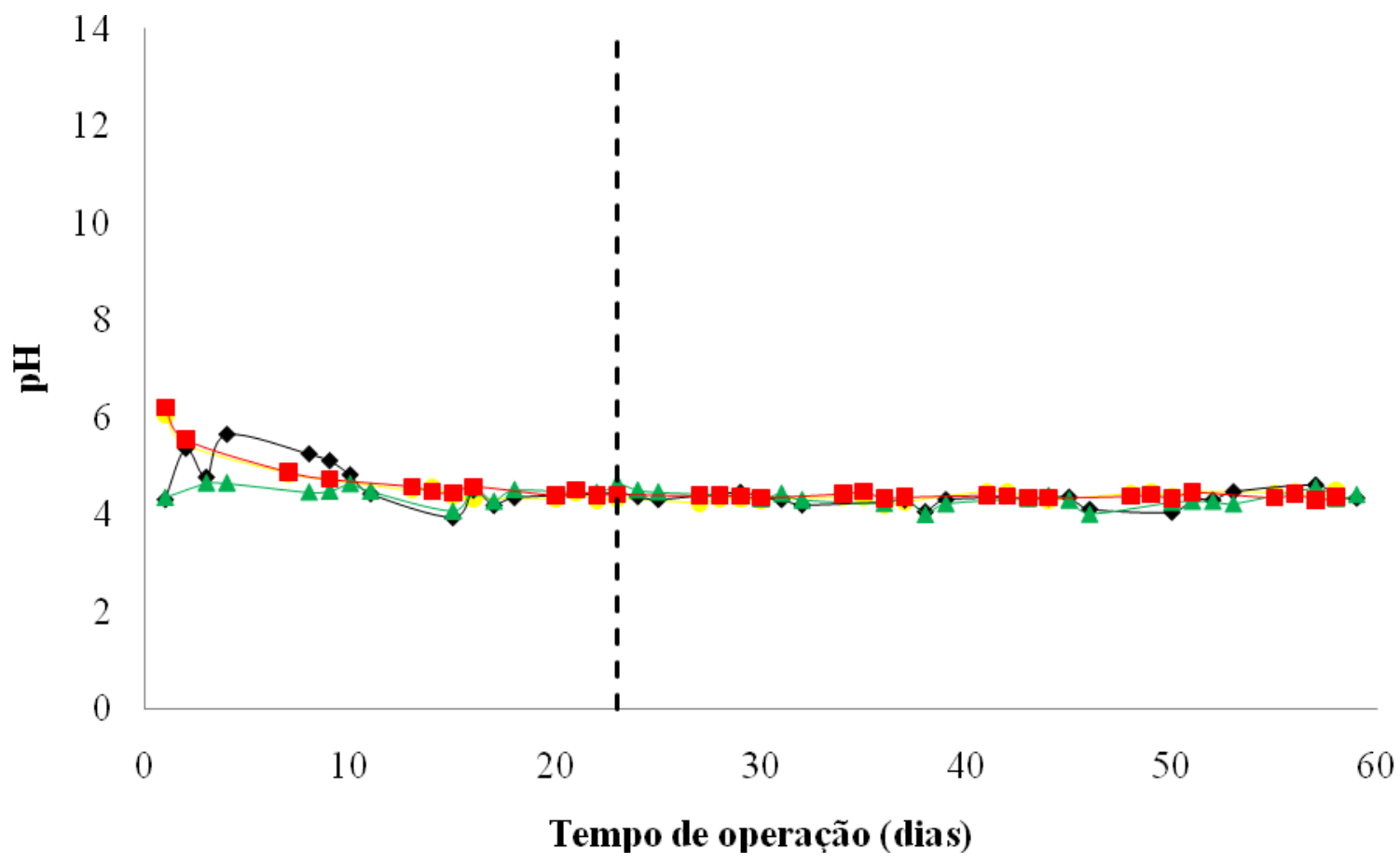

Figura 5.19 - pH no efluente dos reatores para $R=0,25(\odot), R=0,5(\diamond), R=1,0(\Delta)$ e $R=2,0(\square)$. 
Tabela 5.23 - Valores médios e máximos do pH efluente.

\begin{tabular}{lcc}
\hline $\mathbf{R}$ & Média & Máximo \\
\hline 0,25 & $4,49 \pm 0,36$ & 6,06 \\
0,5 & $4,35 \pm 0,37$ & 5,64 \\
1,0 & $4,37 \pm 0,17$ & 4,65 \\
2,0 & $4,52 \pm 0,38$ & 6,21 \\
\hline
\end{tabular}

Desta forma, a instabilidade provavelmente está associada exclusivamente ao biogás gerado. Os componentes do biogás provavelmente estão sendo consumidos por algum microrganismo dentro do leito.

As suposições feitas por Rojas (2010) se encaixam muito bem também para o presente trabalho. A possibilidade de consumo do biogás por organismos metanogênicos pode ser descartada, tendo em vista que as análises cromatográficas não indicaram a presença de metano em nenhuma fase de operação. O consumo do hidrogênio por organismos redutores de sulfato também pode ser descartado, mesmo que nenhuma análise de sulfeto tenha sido feita, tendo em vista que isto não explicaria o consumo concomitante do $\mathrm{CO}_{2}$ da mesma forma que não se explicaria caso ocorresse a metanogênese.

Outra hipótese levantada e refutada por Rojas (2010) foi a ocorrência de homoacetogênese com consumo do hidrogênio e do dióxido de carbono. Refutada porque caso esta hipótese ocorresse, ocorreria um aumento da produção do ácido acético, o que não aconteceu como foi mostrado anteriormente.

Rojas (2010) indica a possibilidade da existência de microrganismos consumidores do biogás produzido. Segundo ela, levando-se em consideração o trabalho realizado por Maintinguer (2009), que utilizou condições semelhantes tanto ao seu trabalho quanto ao presente trabalho, é possível que existam atuando dentro do reator bactérias Knallgas, possivelmente Burkholderia sp. Este tipo de microrganismo, de acordo com Gales (2004), 
utilizaria o $\mathrm{H}_{2}$ como doador de elétrons, o $\mathrm{O}_{2}$ (presente no meio de alimentação, mesmo em pequenas quantidades, ou decorrente da microaeração na alimentação através das mangueiras e ligações) como receptor final de elétrons e o $\mathrm{CO}_{2}$ como fonte de carbono.

\subsection{Perfis dos parâmetros de monitoramento ao longo do reator}

No final de cada fase de operação foram realizados perfis espaciais de $\mathrm{pH}$, eficiência de conversão de sacarose e produção de ácidos e solventes, com o intuito de se observar o comportamento do processo ao longo dos reatores. Os pontos de coleta estão destacados na Figura 5.20, onde o ponto 1 é a entrada do reator, os pontos $2,3,4,5$ e 6 são pontos de amostragem do leito e o ponto 7 é a saída do efluente.

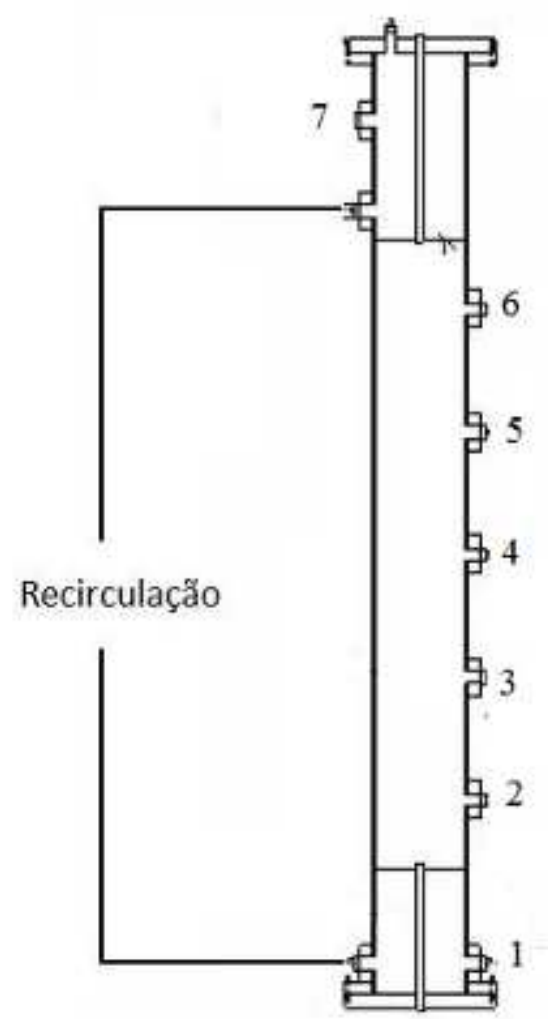

Figura 5.20 - Pontos de coleta para os perfis espaciais 
No perfil espacial do $\mathrm{pH}$ (Figura 5.21) observa-se que os valores permanecem praticamente constantes ao longo do reator, ao contrário do que foi encontrado nos trabalhos de Fernandes (2008), Peixoto (2008) e Rojas (2010), no quais ocorreu uma queda de valores ao longo do leito. Isso mostra que a recirculação promoveu uma mistura do reator, provocando uma maior homogeneização do meio.

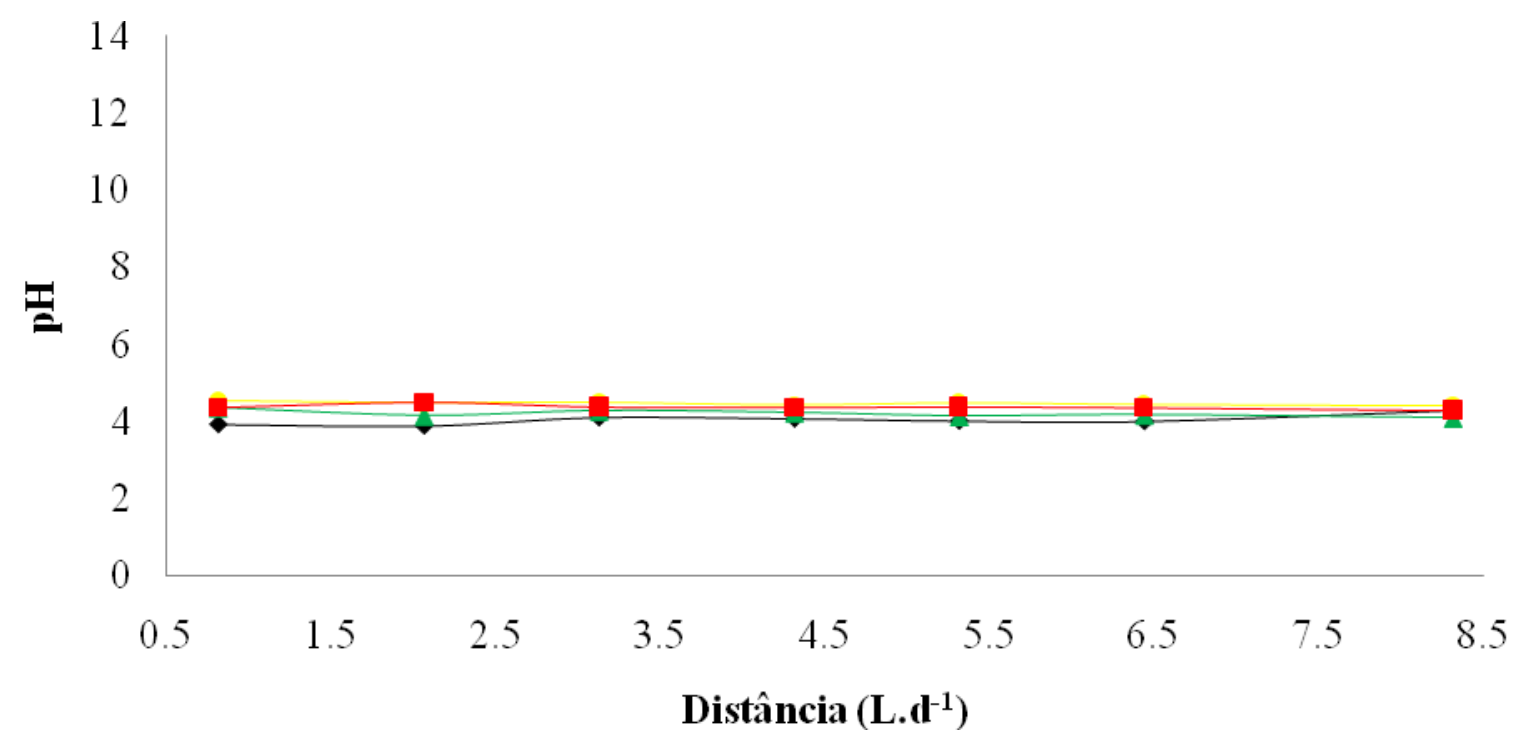

Figura 5.21 - Perfil espacial do pH nos reatores $R=0,25(\bullet), R=0,5(\bullet), R=1,0(\triangle)$ e $R=2,0$ ( $\square$ )

A eficiência de conversão da sacarose (Figura 5.22) também permaneceu praticamente constante em quase todas as fases de operação, mostrando mais uma vez que a recirculação promoveu uma mistura no reator. Apenas $\mathrm{R}=0,25$ apresentou uma variação crescente na eficiência de remoção de sacarose ao longo do reator, como aconteceu nos trabalhos de Fernandes (2008), Peixoto (2008) e Rojas (2010). Isso mostra que à medida que o N vai diminuindo (foi de 31 quando $\mathrm{R}=0,25$ para 4 quando o $\mathrm{R}=2,0$ ) o comportamento hidrodinâmico do reator vai se afastando cada vez mais do pistonado. 


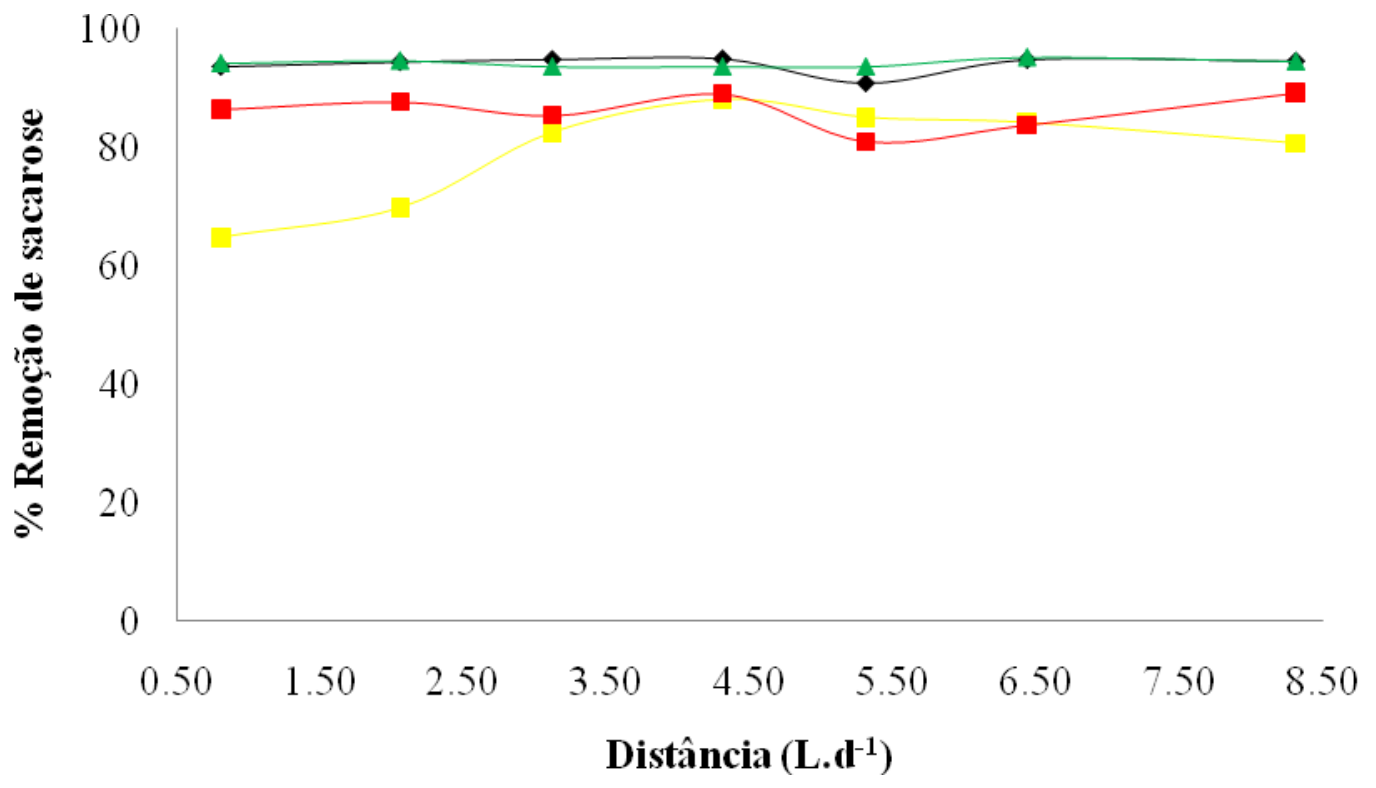

Figura 5.22 - Perfil espacial da eficiência de remoção de sacarose nos reatores $R=0,25(\bullet), \mathbf{R}=\mathbf{0 , 5}$ $(\bullet), R=1,0$ ( $\Delta$ ) e $R=2,0$ ( $\bullet$ ).

A geração de produtos no meio líquido (Figura 5.23 e 5.24) apresentou como principais metabólitos o ácido acético, ácido butírico e etanol, assim como aconteceu no efluente ao longo dos reatores. 

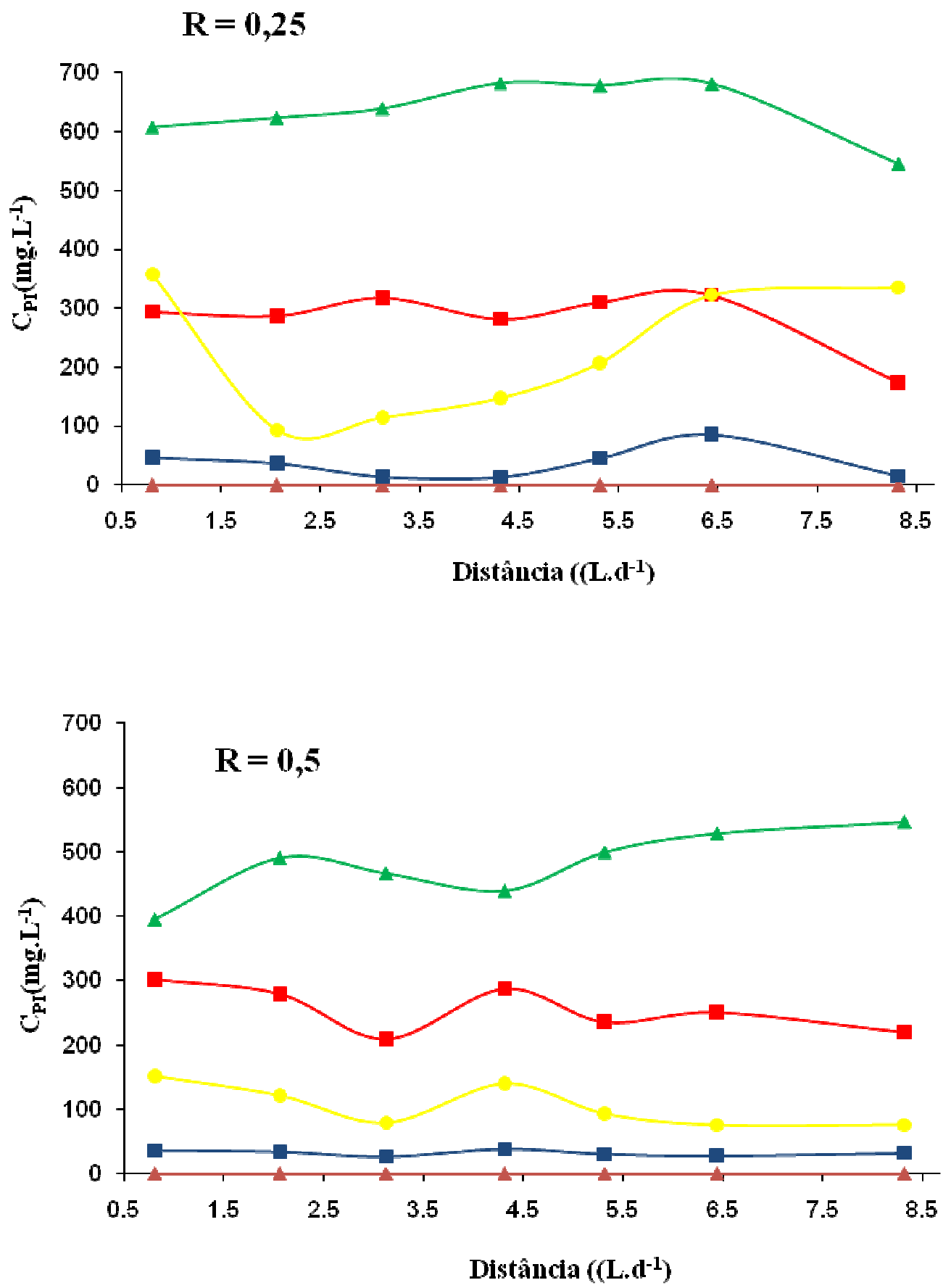

Figura 5.23 - Perfil espacial da geração de produtos intermediários $\left(C_{P I}\right)$ para $R=0,25$ e $R=0,5$ -

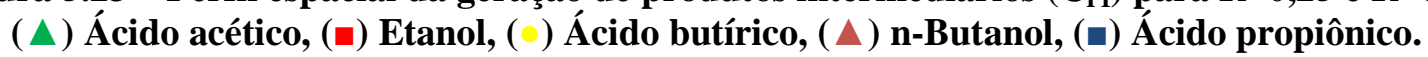



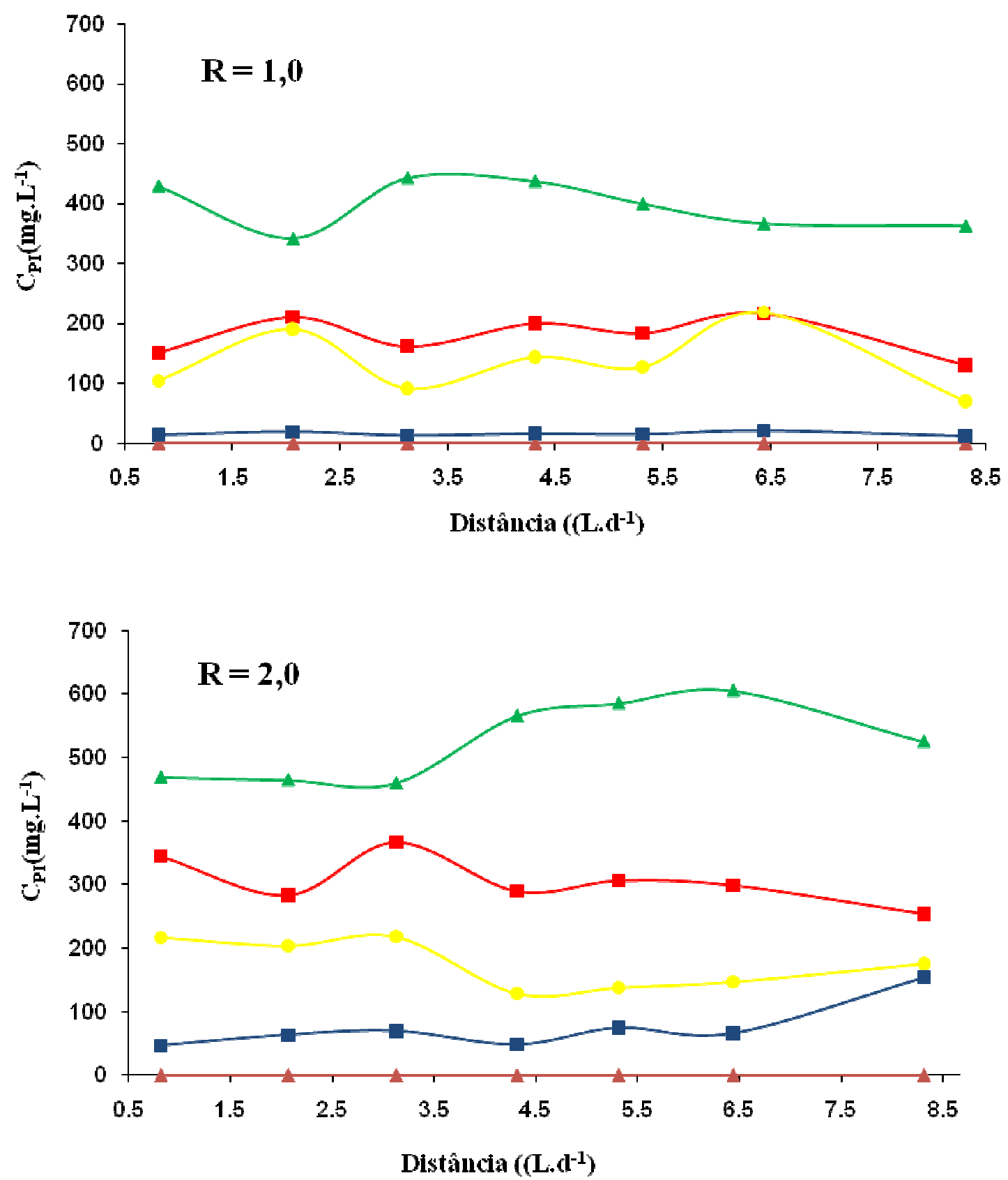

Figura 5.24 - Perfil espacial da geração de produtos intermediários $\left(C_{P I}\right)$ para $R=1,0$ e $R=2,0$ -

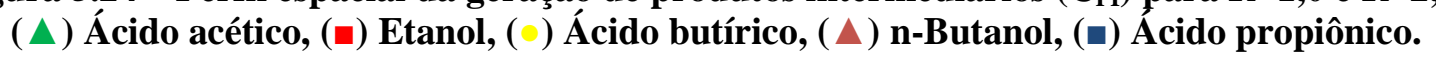

\subsection{Comportamento hidrodinâmico dos reatores após as operações}

Para cada grau de recirculação utilizado foram feitos ensaios hidrodinâmicos sem biomassa (antes do começo da operação) e com biomassa (após os 60 dias de operação). 
Seguindo a metodologia do item 4.9 e com o auxílio do programa Origin $8.0^{\circledR}$ foram obtidas as curvas de distribuição do tempo de residência real em cada fase, como pode se visto na Figura 5.25.

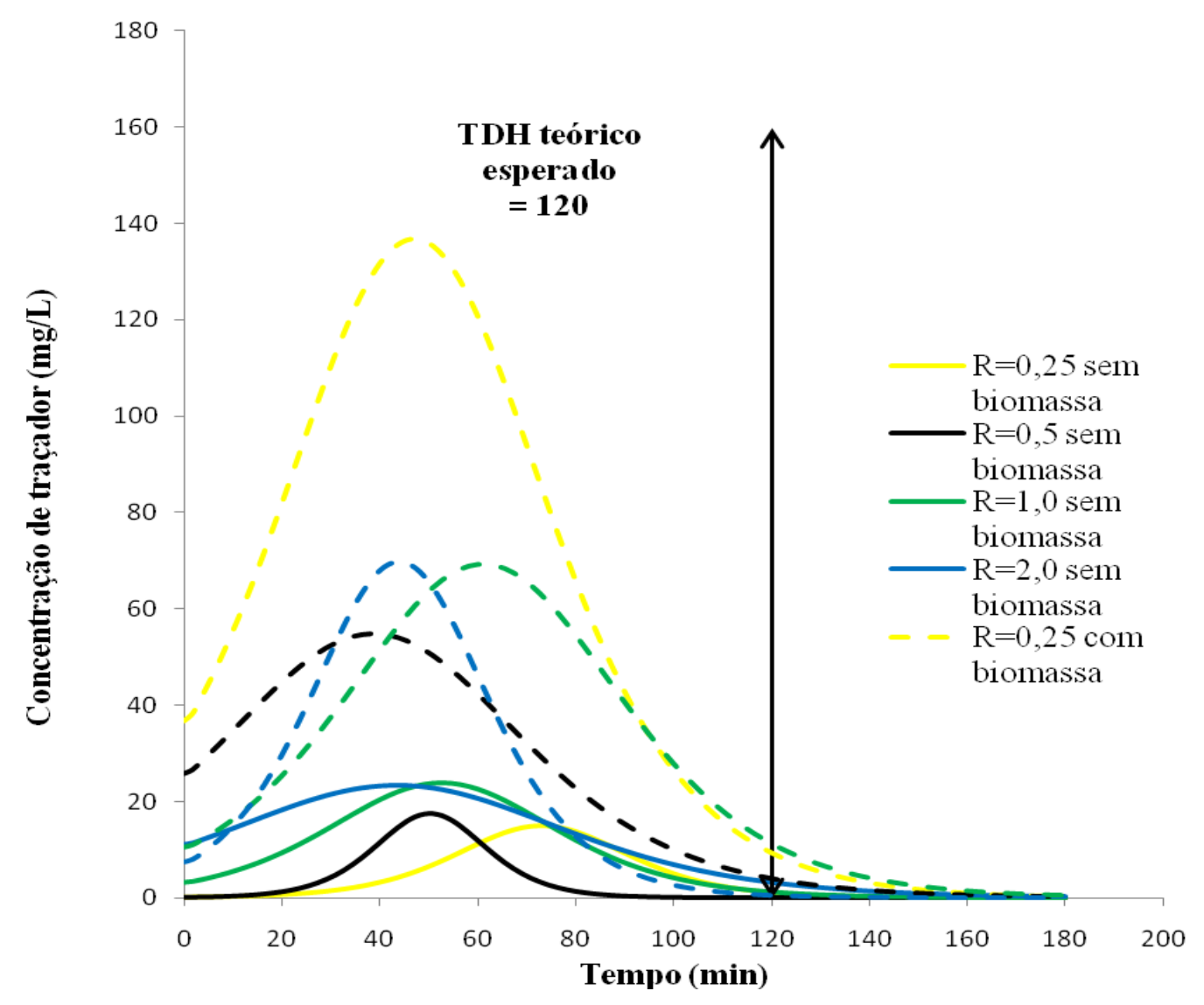

Figura 5.25 - Curvas de Distribuição do Tempo de Retenção (TDH) com e sem biomassa.

A biomassa aderida fez com que o comportamento do escoamento mudasse em relação aos reatores sem biomassa. Para todas as condições o pico das curvas ocorreu antes do TDH teórico esperado ( 2 horas ou 120 minutos). Este comportamento sugere que em todas as condições ocorreram zonas mortas ou caminhos preferenciais (Levenspiel, 2000).

Os valores de variância $\left(\sigma^{2}\right)$ indicaram que a dispersão da distribuição aumentou quando a biomassa estava presente. A Tabela 5.24 apresenta o TDH real, o número de tanques em série, o número de dispersão e a quantidade de biomassa intersticial em cada fase de operação. 
Tabela 5.24 - Dados obtidos nos ensaios hidrodinâmicos.

\begin{tabular}{|c|c|c|c|c|}
\hline Recirculação & TDH (min) & $\mathrm{N}$ & Variância $\left(\sigma^{2}\right)$ & $\begin{array}{c}\text { Biomassa } \\
\text { Intersticial } \\
\left(\mathrm{mg} \cdot \mathrm{g}^{-1} \text { suporte }\right)\end{array}$ \\
\hline $\begin{array}{c}\mathrm{R}=0,25 \mathrm{sem} \\
\text { biomassa }\end{array}$ & 74.96 & 16 & 352.85 & - \\
\hline $\begin{array}{c}\mathrm{R}=0,25 \mathrm{com} \\
\text { biomassa }\end{array}$ & 54.10 & 5 & 602.32 & 89.43 \\
\hline $\begin{array}{c}\mathrm{R}=0,5 \mathrm{sem} \\
\text { biomassa }\end{array}$ & 55.47 & 10 & 295.66 & - \\
\hline $\begin{array}{c}\mathrm{R}=0,5 \text { com } \\
\text { biomassa }\end{array}$ & 50.23 & 2 & 1050.93 & 122.51 \\
\hline $\begin{array}{c}\mathrm{R}=1,0 \text { sem } \\
\text { biomassa }\end{array}$ & 58.99 & 5 & 638.92 & - \\
\hline $\begin{array}{c}\mathrm{R}=1,0 \text { com } \\
\text { biomassa }\end{array}$ & 67.90 & 6 & 764.50 & 95.16 \\
\hline $\begin{array}{c}\mathrm{R}=2,0 \mathrm{sem} \\
\text { biomassa }\end{array}$ & 56.42 & 4 & 874.02 & - \\
\hline $\begin{array}{c}\mathrm{R}=2,0 \text { com } \\
\text { biomassa }\end{array}$ & 46.11 & 7 & 313.69 & 102.61 \\
\hline
\end{tabular}

$\mathrm{O}$ TDH diminui à medida que o $\mathrm{N}$ diminuiu. Não foi possível identificar o real motivo para isso. O mais provável possa ser a formação de caminhos referencias devido à forma como a alimentação e a recirculação foram introduzidas no sistema. O objetivo de se aproximar da mistura perfeita com o aumento da recirculação, porém, foi atingido.

O crescimento de biomassa no meio intersticial se mostrou similar para as vazões de recirculação estudadas. Esse crescimento se mostrou problemático. Porém não foi possível relacionar de forma mais clara a mudança nos parâmetros obtidos nos ensaios hidrodinâmicos com e sem biomassa crescida. Provavelmente este comportamento se deva à forma como o meio suporte foi arranjado, de forma não ordenada. 


\section{Conclusões}

A partir dos resultados obtidos e da discussão apresentada para os experimentos realizados em reatores anaeróbios de leito fixo e fluxo ascendente, com diferentes razões de recirculação $(0,25 ; 0,5 ; 1,0$ e 2,0), utilizando sacarose como substrato, é possível concluir que:

- A razão de recirculação no reator influenciou a produção de hidrogênio, com tendência ao aumento da produção com o aumento do recirculação até atingir um ponto máximo, após o qual há decréscimo na produção com o aumento do grau de mistura.

- Ao variar de forma crescente as razões de recirculação, observou-se a melhor condição de operação para $\mathrm{R}=0,5$. Esta condição apresentou a maior eficiência de conversão de sacarose $(99,18 \%)$, a maior vazão molar $\left(13,76 \mathrm{mmol} \mathrm{H}_{2} \cdot \mathrm{h}^{-1}\right)$, o maior rendimento $(3,95$ mol $\mathrm{H}_{2}$. Mol sac ${ }^{-1}$ ), e a maior produção volumétrica de hidrogênio $\left(289,77 \mathrm{~mL} \mathrm{H}_{2}\right.$.(h.L) $\left.{ }^{-1}\right)$. Nesta mesma condição foram encontrados os melhores valores médios para eficiência de conversão de sacarose, de vazão molar e de produção volumétrica de hidrogênio $(79,22 \%$, $5,92 \mathrm{mmol} \mathrm{H} \cdot \mathrm{h}^{-1}, 124,78 \mathrm{~mL} \mathrm{H}$. $\left.(\mathrm{h} \cdot \mathrm{L})^{-1}\right)$.

- Através de ajustes utilizando uma função polinomial chegou-se a um ponto ótimo com $\mathrm{R}=0,6$, com valores de 4,22 $\mathrm{mmol} \mathrm{H}_{2} \cdot \mathrm{mol} \mathrm{sac}^{-1}$ e $128,13 \mathrm{~mL} \mathrm{H}_{2} \cdot \mathrm{h}^{-1} \mathrm{~L}^{-1}$ para o rendimento máximo e a produção volumétrica de hidrogênio média, respectivamente.

- $\mathrm{O}$ biogás produzido foi composto principalmente por $\mathrm{CO}_{2}$ e $\mathrm{H}_{2}$, apresentando porcentagens médias deste ultimo de $49,75 \%, 55,91 \%, 56,19 \%$ e $45,71 \%$ para $\mathrm{R}=0,25,0,5$, 1,0 e 2,0, respectivamente. Não foi detectada a presença de metano em nenhuma das etapas, mostrando que o método de inoculação utilizado (fermentação natural) foi eficiente.

- Para todas as etapas de operação a distribuição percentual de geração dos principais ácidos no meio líquido foi superior a $65,1 \%$ e 18,8\% para o ácido acético e o ácido butírico, respectivamente. A razão de recirculação de 0,5 apresentou os melhores valores médios de 
porcentagem de ácido acético (73,3 \%). Além disso, a distribuição de alcoóis apresentou valores de etanol acima de $91,1 \%$ em todas as fases de operação, em relação à distribuição de solventes formados (alcoóis e cetona).

- Por meio das análises de microscopia e levando em consideração a semelhança das condições de operação com outros trabalhos que realizaram exames microbiológicos mais completos, além dos ácidos e solventes produzidos, é possível indicar uma provável presença do gênero Clostridium $s p$.

A recirculação mudou o tipo de escoamento ao longo dos reatores, da mesma forma que o crescimento da biomassa intersticial. Isto ocorreu provavelmente devido à formação de caminhos preferenciais ou zonas mortas devido à forma como a alimentação e a recirculação foram empregadas (reatores sem biomassa) e devido à ocupação dos espaços entre o material suporte pela biomassa. 


\section{SugeSTõeS}

Levando em consideração as experiências obtidas no presente trabalho são apresentadas a seguir sugestões para futuros estudos de produção de hidrogênio em reatores anaeróbios de leito fixo:

- Analisar a fase transiente do processo, onde foram obtidos os melhores resultados deste trabalho, bem como de outros trabalhos desenvolvidos no LPB da EESC/USP.

- Mudar a forma de alimentação e recirculação, procurando assim evitar a mudança de regime hidrodinâmico.

- Testar valores de razão de recirculação o mais próxima possível de zero.

- Estudar a influência da transferência de massa através de outros métodos diferentes da recirculação, como agitadores, por exemplo.

- Estudar os efeitos da disposição do material suporte nos reatores para as mesmas condições de operação.

- Estudar a influência da variação da temperatura.

- Realização de um estudo microbiológico mais aprofundado com o intuito de identificar os principais grupos de microrganismos presentes e solucionar a queda na produção do biogás.

- Avaliar a possibilidade de aproveitamento dos alcoóis e solventes, tendo em vista as altas concentrações obtidas, principalmente de etanol. 


\section{REFERÊNCIA BIBLIOGRÁFICA}

AIBA, S.; HUMPHREY, A. E.; MILLIS, N. F. Engenharia bioquímica. Trad. Por Júlio César Medina. Campinas, SP, 1971.

AMORIM, E. L. C. Efeito da concentração de glicose e da alcalinidade na produção de hidrogênio em reator anaeróbio de leito fluidificado. São Carlos. 192 p. Tese (doutorado) - Escola de Engenharia de São Carlos, USP, 2009.

ARGUN, H.; KARGI, F.; PÉREZ, A.; EAPEN, D. Comparison of two anaerobic systems for hydrogen production from the organic fraction of municipal solid waste and synthetic wastewater. International Journal of Hydrogen Energy, v. 32, p. 3141 - 3146, 2007.

ARGUN, H.; KARGI, F.; KAPDAN, I.; OZTEKIN, R. Biohydrogen production by dark fermentation of wheat powder solution: Effects of $\mathrm{C} / \mathrm{N}$ and $\mathrm{C} / \mathrm{P}$ ratio hydrogen yield and formation rate. International Journal of Hydrogen Energy, v. 33, p. 1813-1819, 2008

AROOJ, M. F.; HAN, S. K.; KIM, S. H.; KIM, D. H.; SHIN, H. S. Sludge characteristics in anaerobic SBR system producing hydrogen gas. Water research, v. 41, p. 1177 1184, 2007.

ALZATE, L.; SEBASTIAN, P.J.; KAPDAN, I.; OZTEKIN, R. Biohydrogen production by dark fermentation of wheat powder solution: Effects of $\mathrm{C} / \mathrm{N}$ and $\mathrm{C} / \mathrm{P}$ ratio hydrogen yield and formation rate. International Journal of Hydrogen Energy, v. 33, p. 1813 $-1819,2008$.

ALZATE-GAVIRIA, L. M.; SEBASTIAN, P. J.; PEREZ-HERNANDEZ, A.; EAPEN, D. Comparison of two anaerobic systems for hydrogen production from the organic 
fraction of municipal solid waste and synthetic wastewater. International Journal of Hydrogen Energy, v. 32, p. 3141 - 3146, 2007.

BAHL, H.; ANDERSCH W.; BRAUN, K.; GOTTSCHALK, G. Effect of pH and butyrate concentration on the production of acetone and butanol by Clostridium acetobutylicum grown in continuous culture. Eur. J. Appl. Microbiol. Biotechnol., v. 14, p. 17-20, 1982.

BARROS, A. R. Influência de diferentes materiais suporte na produção de hidrogênio emreator anaeróbio de leito fluidizado. São Carlos. 119 p. Tese (mestrado) - DEQ UFSCar, 2009.

BOXMA, B.; DE GRAAF, R. M.; VAN DER STAAY, G. W. M.; VAN ALEN, T. A.; RICARD, G.; GABALDON, T.; VAN HOEK, A. H. A. M.; MOON-VAN DER STAAY, S. Y.; KOOPMAN, W. J. H.; VAN HELLEMOND, J. J.; TIELENS, A. G. M.; FRIEDRICH, T.; VEENHUIS, M.; HUYNEN, M. A.; HACKSTEIN, J. H. P. An anaerobic mitochondrion that produces hydrogen. Nature. 434 (7029), p. 74-79, 2005.

CHANG, J. J.; WU, J. H.; WEN, F. S.; HUNG, K. Y.; CHEN, Y. T.; HSIAO, C. L.; LIN, C. Y.; HUANG, C. C. Molecular monitoring of microbes in a continuous hydrogenproducing system with different hydraulic retention time. International Journal of Hydrogen Energy, v. 33, p. 1579 - 1585, 2008.

CHANG, J. S.; LEE, K. S.; LIN, P. J. Biohydrogen production with fixed-bed bioreactor, International Journal of Hydrogen Energy, v. 27, p. 1167 - 1174, 2002.

CHANG, F. Y.; LIN, C. Y. Biohydrogen production using an up-flow anaerobic sludge blanket reactor. International Journal of Hydrogen Energy, v. 29. P. 33 - 39, 2004.

CHEN, C. C.; CHEN, H. P.; WU, J. H.; LIN, C. Y. Fermentative hydrogen production at high sulfate concentration. International Journal of Hydrogen Energy, v. 33, p. 1573 $1578,2008$. 
CHEN, C. C.; LIN, C. Y.; CHANG, J. S. Kinetics of hydrogen production with continuous anaerobic cultures utilizing sucrose as the limiting substrate. Applied Microbiology Biotechnology, v. 57, p. $56-64,2001$.

CHEN, C.C.; LIN, C.Y. Using sucrose as a substrate in an anaerobic hydrogen-producing reactor. Advances in Environmental Research, v. 7, p. 695 - 699, 2003.

CHEONG, D.; HANSEN, C. Feasibility of hydrogen production in thermophilic mixed fermentation by natural anaerobes. Bioresource Technology, v. 98, p. 2229 - 2239, 2007.

CHERNICHARO, C. A. L. Reatores anaeróbios. Princípios do tratamento biológico de águas residuárias, v. 5, 2ª Ed, Minas Gerias, Departamento de Engenharia Sanitária e Ambiental, UFMG, 1997.

DAS, D. Advances in biohydrogen production processes: An approach towards commercialization. International Journal of Hydrogen Energy, v. 34, p. 7349-7357, 2009.

DAS, D.; VEZIROGLU, T. Hydrogen production by biological processes: a survey of literature.. International Journal of Hydrogen Energy, v. 26, p. 13 - 28, 2001.

DEL NERY, V. Utilização de lodo anaeróbio imobilizado em gel no estudo de partida de reatores de fluxo ascendente com manta de lodo. Dissertação (mestrado), Escola de Engenharia de São Carlos, USP, 1987.

DUBOIS, S. M.; GILlES, K. A.; HAMILTON, J. L.; REBERS, P. A.; SMITH, F., Colorimetric Methods for determination of sugar and related substance. Analytical Chemistry, v. 228, p. 13-21, 1956.

ENDO, G.; NOIKE, T.; MATSUMOTO, J. Characteristics of cellulose and glucose decomposition in acidogenic phase of anaerobic digestion. Proc. Soc. Civ. Engrs., v. 325, p. 61-68, 1982. 
FANG, H. H. P.; LIU, H.; ZHANG, T. Characterization of a hydrogen-producing granular sludge. Biotechnol Bioeng, v. 78, p. 44 - 52, 2002.

FERNANDES, B. S. Produção de hidrogênio em reator anaeróbio de leito fixo. São Carlos. 116 p. Tese (doutorado) - Escola de Engenharia de São Carlos, USP, 2008.

FRITSCH, M.; HARTMEIER, W.; CHANG, J-S. Enchancing hydrogen production of Clostridium butyricum using a column reactor with square-structured ceramic fitting. International Journal of Hydrogen Energy, v. 33, p. 6549 - 6557, 2008.

GALES, G.; LIBERT, M. F.; SELLIER, R.; COURNAC, L.; CHAPON, V.; HEULIN, T. Molecular hydrogen from water radiolysis as an energy source for bacterial growth in a basin containing irradiating waste. Fems Microbiology Letters, v. 240, p. 155-162, 2004.

HAN S. K.; SHIN H. S. Biohydrogen production by anaerobic fermentation of food waste, International Journal. of Hydrogen Energy, v. 29, p. 569 - 577, 2004.

HAHN, J. J. Hydrogen production from biomass. Tese (doutorado) - Faculty of the Graduate School at the University of Missouri-Columbia, 116 p. 2006.

HAWKES, F. R.; DINSDALE, R.; HAWKES D. L.; HUSSY I. Sustainable fermentative hydrogen production: Challenges for process optimization. International Journal of Hydrogen Energy, v. 27, p. 1339 - 47, 2002.

HORVÁTH, I. C. Hydraulics in water and wastewater treatment technology. John Wiley \& Sons, Hungary, p. 319, 1994.

HUANG, G. H.; HSU, S. F.; LIANG, T. M.; HUANG, Y. H. Study on hydrogen production with hysteresis in UASB. Chemosphere, v. 54, p. 815 - 821, 2004.

HUNG, C. H.; CHENG, C. H.; CHENG, L. H.; LIANG, C. M.; LIN, H. Y. Application of Clostridium-specific PCR primers on the analysis of dark fermentation hydrogen- 
producing bacterial community. International Journal of Hydrogen Energy, v. 33, p. $1586-1592,2008$.

ITO, T.; NAKASHIMADA, Y.; SENBA, K.; MATSUI, T.; NISHIO, N. Hydrogen and ethanol production from glycerol containing wastes discharges after biodiesel manufacturing process. Journal of Bioscience and Bioengineering, v. 100, p. 260-265, 2005.

JEONG, T.; CHA, G.; YOO, I.; KIM, D. Hydrogen production from waste activated sludge by using separation membrane acid fermentation reactor and photosynthetic reactor. International Journal of Hydrogen Energy, v. 32, p. 525-530, 2007

KAWAGOSHI, Y.; HINO, N.; FUJIMOTO, A.; NAKAO, M.; FUJITA, Y.; SUGIMURA, S.; FURUKAWA, K. Effect of inoculum conditioning on hydrogen fermentation and $\mathrm{pH}$ effect on bacterial community relevant to hydrogen production. Journal of Bioscience e Bioengineering, v. 100, p. 524-530, 2005.

LAMED, R., J. LOBOS, J. H., SU, T. M. Effects of stirring and hydrogen on fermentation products of clostridium thermocellum. Applied and Environmental Microbiology, v. 54, p. 1216-1221, 1998.

LAY, J. J.; LEE, Y. J.; NOIKE, T. Feasibility of biological hydrogen production from organic fraction of municipal solid waste. Water Research, v. 33, nº 11, p. 2579 - 2586, 1999.

LAY, J. J. Biohydrogen generation by mesophilic anaerobic fermentation of microcrystalline cellulose. Biotechnol Bioeng, v. 74, p. 280 - 287, 2001.

LEE, K. S.; LO, Y. S.; LO, Y. C.; LIN, P. J.; CHANG, J. S. $\mathrm{H}_{2}$ production with anaerobic sludge using activated-carbon supported packed-bed bioreactor. Biotechn. Letter, v. 25, p. 133-138, 2003.

LEE, K.; LO, Y. S.; LO, Y.C.; LIN, P.; CHANG, J. H2 production with anaerobic sludge using activated-carbon supported packed-bed bioreactors. International Journal of Hydrogen Energy, v. 33, p. 579-586, 2008. 
LEITE, J. A. C.; FERNANDES, B. S.; POZZI, E.; BARBOZA, M.; ZAIAT, M. Application of an anaerobic packed-bed bioreactor for the production of hydrogen and organic acids. International Journal of Hydrogen Energy, v. 33, p. 579-586, 2008.

LETTINGA, G.; REBAC, S.; ZEEMAN, G. Challenge of psychrophilic anaerobic wastewater treatment. Trends in Biotechnology, v. 19, p. 363 - 370, 2001.

LEVENSPIEL, O. Chemical reaction engineering. 3.ed. New York, John Wiley \& Sons Inc., 2000.

LEVIN, D. B.; PITT, L.; LOVE, M. Biohydrogen production: prospects and limitations to practical application. International Journal of Hydrogen Energy, v. 29, p. 173 - 85, 2004.

LI, J.; LI, B.; ZHU, G.; REN, N.; BO, L.; HE, J. Hydrogen production from diluted molasses by anaerobic hydrogen producing bacteria in an anaerobic baffled reactor (ABR). International Journal of Hydrogen Energy, v. 32, p. 3274 - 3283, 2007.

LIANG, T. M.; CHENG, S. S.; WU, K. L. Behavioral study on hydrogen fermentation reactor installed with silicone rubber membrane. International Journal of Hydrogen Energy; v. 27, p. $1157-1165,2002$.

LIN, C. Y.; CHANG, R. C. Fermentative hydrogen production at ambient temperature. International Journal of Hydrogen Energy, v. 29, p. 715 - 720, 2004.

LIN, C.; LAY, C. Carbon/nitrogen ratio effect on fermentative hydrogen production by mixed microflora. International Journal of Hydrogen Energy, v. 29, p. 41 - 45, 2004.

LIN, C. Y.; LAY, C. H. A nutrient formulation for fermentative hydrogen production using anaerobic sewage sludge microflora. International Journal of Hydrogen Energy, v. 30, p. $285-292,2005$.

LIU, H.; FANG, H. H. P. Hydrogen production from wastewater by acidogenic granular sludge. Water Science and Technology; v. 47,p. 153-158, 2002. 
LIU, X.; ZHU, Y.; YANG, S. T. Butyric acid and hydrogen production by Clostridium tyrobutyricum ATCC 25755 and mutants. Enzyme and Microbial Technology, v 38, p $521-528,2006$.

MAINTINGUER, S. I.; FERNANDES, B. S.; DUARTE, I. C. S.; SAAVEDRA, N. K.; ADORNO, M. A. T.; M. B. VARESCHE, M. B. Fermentative hydrogen production by microbial consortium. International Journal of Hydrogen Energy, v. 33, p. 43094317, 2008.

MAINTINGUER, S. I. Obtenção e caracterização filogenérica de consórcio bacteriano utilizado em reator anaeróbio em batelada aplicado à produção de hidrogênio. São Carlos. 167 p. Tese (doutorado) - Escola de Engenharia de São Carlos, USP, 2009

MATHEWS, J.; WANG, G. Y. Metabolic pathway engineering for enhanced biohydrogen production. International Journal of Hydrogen Energy, v. 34, p. 7404-7416, 2009.

MIZUNO, O.; DINSDALE, R.; HAWKES, F. R.; HAWKES, D. L.; NOIKE, T. Enhancement of hydrogen production form glucose by nitrogen gas sparging. Bioresource Technology, v. 73, p. $59-65,2000$.

MOHAN, S. V.; BABU, V. L.; SARMA, P. N. Effect of various pretreatment methods on anaerobic mixed microflora to enhance biohydrogen production utilizing dairy wastewater as substrate. Bioresource Technology, v. 99, p. 59 - 67, 2008.

MU, Y.; YU, H. Q.; WANG, G. A kinetic approach to anaerobic hydrogen-producing process. Water Research, v. 41, p. 1152 - 1160, 2007.

NARAYANAN, B.; SUIDAN, M. T.; GELDERLOOS, A. B.; BRENNER, R. C. Anaerobic treatment of volatile and semi-volatile organic compounds in municipal wastewater. Research Journal of WEF, v.67, p.45 - 56, 1995.

NISHIO, N.; NAKASHIMADA, Y. Recent development of digestion process for energy recovery from wastes. Journal of Bioscience and Bioengineering, v. 103, p. 105- 
$112,2007$.

NTAIKOU, I.; GAVALA, H. N.; KORNAROS, M.; LYBERATOS, G. Hydrogen production of sugars and sweet sorghum biomass using Ruminococcus albus. International Journal of Hydrogen Energy, v. 33, p. 1221 - 1231, 2008.

OH, S. E.; VAN GINKEL, S.; LOGAN, B. E. The relation effectiveness of pH control and heat treatment for enhancing biohydrogen gas production. Environmental. Science. Technology, v. 37, p 5186 - 5190, 2003.

O-THONG, S., PRASERTSAN, P, INTRASUNGKHA, N; DHAMWICHUKORN, S; BIRKELAND, N. K. Optimization of simultaneous thermophilic fermentative hydrogen production and COD reduction from palm oil mill effluent by Thermoanaerobacterium-rich sludge. International Journal of Hydrogen Energy, v. 33, p. 1221-1231, 2008.

OZTEKIN, R.; KAPDAN, I.; KARGUI, F.; ARGUN, H. Optimization of media composition for hydrogen gas production from hydrolyzed wheat starch by dark fermentation. International Journal of Hydrogen Energy, v. 33, p. 4083 - 4090, 2008.

PAUSS, A.; ANDRE, G.; PERRIER, M.; GUIOT, S. R. Liquid-to-gas mass transfer in anaerobic processes: inevitable transfer limitations of methane and hydrogen in the biomethanation process. Applied and Environmental Microbiology, v. 56 (6), p. $1636-1644,1990$.

PEIXOTO, G. Produção de hidrogênio em reator anaeróbio de leito fixo e fluxo ascendente.a partir de água residuária de industria de refrigerantes. São Carlos. 107 p. Tese (mestrado) - Escola de Engenharia de São Carlos, USP, 2008.

REIS, C. M. Efeito da velocidade e do tempo de detenção hidráulica na produção de hidrogênio em reator anaeróbio de leito fluidizado. São Carlos. 112 p. Tese (mestrado) - DEQ - UFSCar, 2010. 
REITH, J. H.; WIJFFELS, R. H.; BARTEN, H. Introduction: the perspectives of biological methane and hydrogen production, in Bio-methane and Bio-hydrogen. Dutch Biological Hydrogen Foundation Publisher, Hagen, p. 9 - 13, 2003.

REN, N.; XING, D.; RITTMAN, B.; ZHAO, L.; XIE, T.; ZHAO, X. Microbial community structure of ethanol type fermentation in bio-hydrogen production. Environmental Microbiology, v. 9, nº 5 p. $1112-1125,2007$.

Rodrigues, J. A .D.; Ratusznei, S. M.; Camargo, E. F. M; Zaiat, M. Influence of Agitation Rate on the Performance of an Anaerobic Sequencing Batch Reactor Containing Granulated Biomass Treating Low-Strength Wastewater, Advances in Environmental Research, v. 7, p. 405, 2003.

ROGERS, P.; GOTTSCHALK, G. Biochemistry and regulation of acid and solvent production in Clostridia. In: Woods, D.R. (Ed.), The Clostridia and Biochemistry. Butterworth- Heinemann, Stoneham, Mass, p. 25 - 50, 1993.

ROJAS, M. P. A. Influência da relação C/N na produção de hidrogênio em reator anaeróbio de leito fixo. São Carlos. 89 p. Tese (mestrado) - Escola de Engenharia de São Carlos, USP, 2010.

ROMLI, M.; GREENFIELD, P. F.; LEE, P. L. Effect of recycle on a two-phase high- rate anaerobic wastewater treatment system. Water Research, v. 28, p. 475 - 482, 1994.

SABOURIN-PROVOST, G.; HALLENBECK, P.C. HIGH YIELD CONVERSION OF A CRUDE GLYCEROL FRACTION FROM BIODIESEL PRODUCTION TO HYDROGEN BY PHOTOFERMENTATION. BIORESOURCE TECHNOLOGY, V. 100, P. 3513-3517, 2009.

SHIN, J. H.; YOON, J. H.; AHN, E. K.; KIM, M. S.; SIM, S. J.; PARK, T. H. Fermentative hydrogen production by the newly isolated Enterobacter asburiae SNU-1. International Journal of Hydrogen Energy; v. 32, p. 192 - 199, 2007 
SIRIWONGRUNGSON, V.; ZENG, R. J.; ANGELIDAKI, I. Homoacetogenesis as the alternative pathway for $\mathrm{H} 2$ sink during thermophilic anaerobic degradation of butyrate under suppressed methanogenesis. Water Research, v. 41, p. 4204 - 4210, 2007.

SPEECE, R. E. Anaerobic biotechnology for industrial wastewaters. Editora J. M. Speece. Capítulo 3, p. 25, 1996.

SREEKRISHAN, T. R.; RAMACHANDRAN, K. B.; GHOSH, P. Effect of operating variables on biofilm formation and performance of an anaerobic fluidized bed bioreactor. Biotechnology and Bioengineering, v.37, p.557-566, 1991.

TAGUCHI, F.; MIKUKAMI, N.; SAITO-TAKI, T.; HASEGAWA, K. Hydrogen production from continuous fermentation of xylose during growth of Clostridium sp. Strain No. 2. Can. J. Microbiol, v. 41, p. 536 - 540, 1995.

TURCOT, J.; BISAILLON, A.; HALLENBECK, P. Hydrogen production by continuous cultures of Escherichia coli under different nutrient regimes. International Journal of Hydrogen Energy, v. 33, p. 1465-1470, 2008.

VALDEZ-VAZQUEZ, I.; RIOS-LEAL E.; ESPARZA-GARCIA F.; CECCHI F.; POGGIVARALDO H.M. Semi-continuous solid substrate anaerobic reactors for $\mathrm{H} 2$ production from organic waste: mesophilic versus thermophilic regime. International Journal of Hydrogen Energy, v. 30, p. 1383-91, 2005.

VAN GINKEL, S.; SUNG, S. Biohydrogen production as a function of $\mathrm{pH}$ and substrate concentration. Environmental Science \& Technology, v. 35, no 24 p. 4726 - 4730, 2001.

VEZIROGLU, T.N.; BARBIR, F. Hydrogen: The wonder fuel. International Journal of Hydrogen Energy, v. 17, nº 6, p. $391-404,1992$.

VEZIROGLU, T.N.; SAHIN, S. $21^{\text {st }}$ Century's energy: Hydrogen energy system. Energy Conversion and Management, v. 49, p. 1820 - 1831, 2008. 
VIJAYARAGHAVAN, K.; SOOM, M. A. M. Trends in biological hydrogen production - a review. International Journal of Hydrogen Energy, in press, 2004.

VON SPERLING, M. Princípios básicos do tratamento de esgotos. Minas Gerais : Editora UFMG, 1996.

WU, S. Y.; LIN, C. N.; CHANG, J. S.; LEE, K. S.; LIN, P. J. Microbial hydrogen production with immobilized sewage sludge, Biotechnology Progress, v. 18, p. 921- 926, 2002.

WU, S. Y.; LIN, C. N.; CHANG, J. S.; LEE, K. S.; LIN, P. J. Hydrogen production with immobilized sewage sludge in three-phase fluidized-bed bioreactor, Biotechnology Progress, v. 19, p. 828 - 832, 2003.

YANG, Y.; TSUKAHARA, K.; SAWAYAMA, S. Biodegradation and methane production from glycerol-containing synthetic wastes with fixed-bed bioreactor under mesophilic and thermophilic anaerobic conditions. Process Biochemistry, v. 43, p. 362-367, 2008.

ZHANG, Y.; SHEN, J. Effect of temperature and iron concentration on the growth and hydrogen production of mixed bacteria. International Journal of Hydrogen Energy, v. 31, p. $441-446,2005$. 